\title{
Icosahedral Meta-Carboranes Containing Exopolyhedral B-Se and B-Te Bonds
}

\author{
Harrison A. Mills, ${ }^{\dagger}$ Fadi Alsarhan,${ }^{\dagger}$ Ta-Chung Ong,${ }^{\dagger}$ Milan Gembicky, ${ }^{\dagger}$ Arnold L. \\ Rheingold, $₫$ Alexander M. Spokoyny ${ }^{*} \dagger, \S$ \\ $†$ Department of Chemistry and Biochemistry, University of California, Los Angeles, Los \\ Angeles, California 90095, United States \\ †Department of Chemistry and Biochemistry, University of California, San Diego, La \\ Jolla, California 92093, United States \\ $\S$ California NanoSystems Institute (CNSI), University of California, Los Angeles, 570 \\ Westwood Plaza, Los Angeles, California 90095, United States

\section{SUPPLEMENTARY INFORMATION}

\author{
Email: spokoyny@chem.ucla.edu
}


Table of Contents

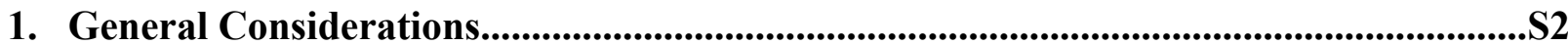

2. Instrumentation........................................................................................................................S3

3. Precursor Synthesis (1A-B) .................................................................................................

4. Synthesis of Electrophilic Reagents $(2 \mathrm{~A}, 3 \mathrm{~A}, 4 \mathrm{~A})$..................................................................55

5. Reactions of Selenyl (II) Chloride (2A) .................................................................................... 7

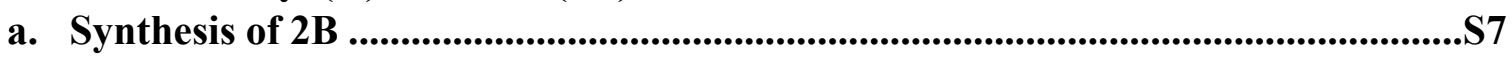

b. General Procedure for Compounds 2C-E....................................................................S7

c. Synthesis of 2F ................................................................................................................59

d. Comparison of High and Low-Field (400-600 MHz) ${ }^{1} \mathrm{H}$ NMR Spectroscopy of

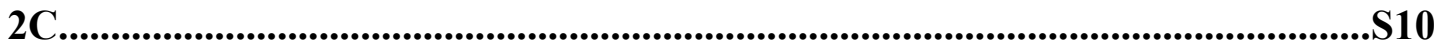

e. GC-MS Trace of Isolated 2C and 2C' Mixture.........................................................S10

f. GC-MS Trace of Isolated 2F....................................................................................S11

g. Experiments with Perdeuterated Toluene...................................................................S11

6. Reactions of Tellurenyl (II) Chloride (3A) …………..............................................................S12

a. Synthesis of 3B .............................................................................................................S12

b. Reaction of 3A with Phenylacetylene in Dichloromethane.......................................S13

c. Reaction of 3A with Phenylacetylene in Chloroform..................................................S14

7. Reactions of Tellurenyl (IV) Chloride (4A) ...........................................................................S14

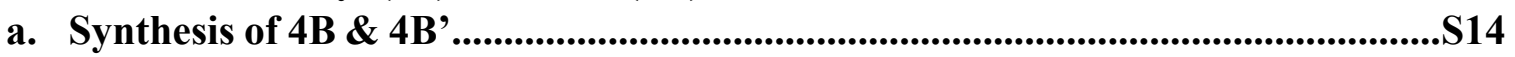

b. Radical Mechanism Inhibition Experiments...............................................................S15

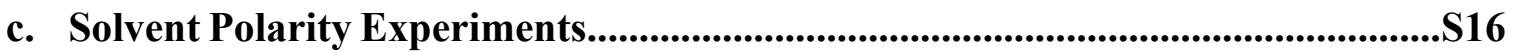

8. Synthesis and Nucleophilic Reactions of Selenol (5A-B) .....................................................S17

a. Synthesis of 5A................................................................................................................

b. Synthesis of 5B...................................................................................................................

9. Synthesis and Nucleophilic Reactions of Tellurol (6A-C) ...................................................S18

a. Synthesis of 6A....................................................................................................................518

b. Synthesis of 6B..................................................................................................................519

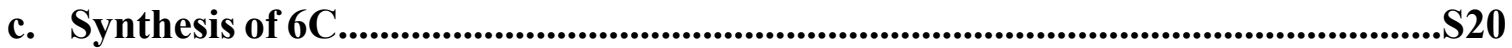

d. In situ ${ }^{11}$ B NMR Spectroscopy of Crude 6A..................................................................S20

10. X-ray Crystallography Details..................................................................................................S21

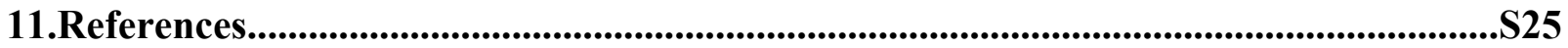

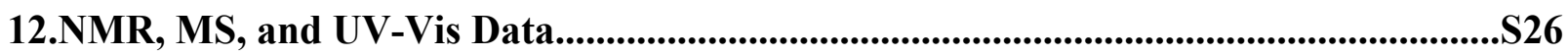

\section{General Considerations}

Meta- $\mathrm{C}_{2} \mathrm{~B}_{10} \mathrm{H}_{12}$ (Katchem or Alfa Aesar) was used as is. Dry dichloromethane was obtained from a Grubbs column with activated alumina and copper catalyst. For the synthesis of 1B, dichloromethane was further dried by stirring over $\mathrm{CaH}_{2}$ for $24 \mathrm{~h}$ before distilling the solvent into the reaction flask. $\mathrm{Se}_{2} \mathrm{Cl}_{2}$ used in the synthesis of $\mathbf{1 A}$ was prepared according to the procedure found in reference 1 and subsequently stored in a PTFE-capped vial at $-15^{\circ} \mathrm{C} . \mathrm{TeCl}_{4}$ used in the synthesis of $1 \mathrm{~B}$ was prepared according the procedure found in reference 2 and stored in a $\mathrm{N}_{2}$ - 
filled glovebox at $-30{ }^{\circ} \mathrm{C}$. [4-tolyl-PdRuPhos][OTf] used in the synthesis of $\mathbf{6 C}$ was prepared following procedures found in reference 3 . All other reagents were purchased from commercial vendors and used as is. Unless otherwise stated, all reactions and manipulations were performed under ambient atmosphere of laboratory air exposed to ambient light.

Plastic-backed Baker-flex Silica Gel IB2-F TLC plates were used for thin layer chromatography. Silica used for flash column chromatography was SiliaFlash ${ }^{\circledR}$ G60 60-200 $\mu \mathrm{m}$ (70-230 mesh) purchased from Silicycle. TLC samples for carborane-containing compounds were stained with 1 wt. $\% \mathrm{PdCl}_{2}$ in $6 \mathrm{M} \mathrm{HCl}$ and developed with heat using a Master Appliance VT-750C Varitemp Heat Gun at full heat for 30-60 seconds (until spots develop).

\section{Instrumentation}

${ }^{1} \mathrm{H},{ }^{13} \mathrm{C}\left\{{ }^{1} \mathrm{H}\right\},{ }^{11} \mathrm{~B},{ }^{11} \mathrm{~B}\left\{{ }^{1} \mathrm{H}\right\},{ }^{19} \mathrm{~F},{ }^{77} \mathrm{Se}$, and ${ }^{125} \mathrm{Te}$ NMR spectra were recorded on either a Bruker AVI 600, Bruker DRX500, or Bruker AVIII HD 400 spectrometers in ambient conditions at room temperature. MestReNova v6.0.2-5475 software was used to process the FID data and visualize the spectra. ${ }^{1} \mathrm{H}$ and ${ }^{13} \mathrm{C}\left\{{ }^{1} \mathrm{H}\right\}$ NMR spectra were referenced to residual solvent resonances in deuterated solvents (note: due to high humidity $\mathrm{H}_{2} \mathrm{O}$ resonances are often present) and are reported relative to tetramethylsilane $(\delta=0 \mathrm{ppm}) .{ }^{11} \mathrm{~B}$ and ${ }^{11} \mathrm{~B}\left\{{ }^{1} \mathrm{H}\right\}$ NMR spectra were referenced externally to $\mathrm{Et}_{2} \mathrm{O} \cdot \mathrm{BF}_{3}(\delta=0 \mathrm{ppm}) .{ }^{19} \mathrm{~F}$ NMR spectra were referenced externally to fluorobenzene $(\delta=-$ $113.15 \mathrm{ppm}) .{ }^{77} \mathrm{Se}$ NMR spectra were referenced externally to diphenyldiselenide $(\delta=463.15$ $\mathrm{ppm}) .{ }^{125} \mathrm{Te}$ NMR spectra were referenced externally to diphenylditelluride in tetrahydrofuran at room temperature $(\delta=408 \mathrm{ppm})$. Exponential apodization $(5-30 \mathrm{~Hz})$ was applied through MestReNova to ${ }^{77} \mathrm{Se}$ and ${ }^{125} \mathrm{Te}$ NMR spectra for most compounds reported in order to enhance the signal to noise ratio.

GCMS measurements were carried out using an Agilent Model 7683 Autosampler, 6890 Gas Chromatograph, and 5975 Inert Mass Selective Detector in the Electron Impact (EI) mode. EI energy was set to $70 \mathrm{eV}$. Data collection was controlled using MSD Enhanced Chemstation software (Agilent). Separation was carried out on an Agilent HP5-MS column with dimensions $30 \mathrm{~m}$ x $250 \mathrm{um} \times 0.25 \mathrm{um}$. Ultra High Purity Grade He (Airgas) was used as carrier gas with the flow set to $0.8 \mathrm{ml} / \mathrm{min}$ in constant flow mode.

UV-Vis absorption measurements were taken using an Ocean Optics Flame Miniature Spectrometer detector and Ocean Optics DH-2000 UV-Vis-NIR source. All samples were dissolved in THF and measurements were taken in a $1 \mathrm{~cm}$ quartz cuvette.

Elemental analysis of compounds $\mathbf{1 A}$ and $\mathbf{1 B}$ was performed by Atlantic Microlabs.

\section{Precursor Synthesis}

\section{Synthesis of $1 \mathrm{~A}$}




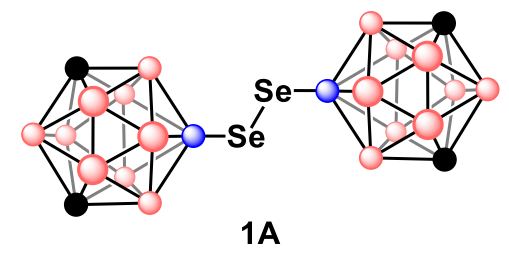

$1 \mathrm{~A}$

Synthetic procedures adapted from reference 4. Meta- $\mathrm{C}_{2} \mathrm{~B}_{10} \mathrm{H}_{12}$ $(1.44 \mathrm{~g}, 10 \mathrm{mmol})$ and $\mathrm{AlCl}_{3}(1.33 \mathrm{~g}, 10 \mathrm{mmol}, 1 \mathrm{eq})$ were added to an oven-dried Schlenk flask equipped with a stir bar and rubber septum and evacuated/backfilled with $\mathrm{N}_{2}$ three times. Anhydrous $\mathrm{CH}_{2} \mathrm{Cl}_{2}(25 \mathrm{ml})$, collected from a Grubb's column, was added to the Schlenk flask via cannula and the solids were allowed to dissolved. Subsequently, $\mathrm{Se}_{2} \mathrm{Cl}_{2}(0.42$ $\mathrm{mL}, 5 \mathrm{mmol}, 0.5 \mathrm{eq}$ ) was added dropwise to the stirring suspension via syringe, forming a dark red solution that was allowed to stir overnight at room temperature. Upon completion of the reaction, determined by TLC, the reaction was carefully quenched by the addition of distilled $\mathrm{H}_{2} \mathrm{O}(15 \mathrm{~mL})$, yielding a dark yellow, cloudy suspension. The yellow organic later was separated from the aqueous layer and the aqueous layer was extracted with $\mathrm{CH}_{2} \mathrm{Cl}_{2}(3 \times 15 \mathrm{~mL})$. The organic layers were combined and dried with $\mathrm{Na}_{2} \mathrm{SO}_{4}$, resulting in a clear yellow/orange solution. The solution was then decanted from the $\mathrm{Na}_{2} \mathrm{SO}_{4}$ and silica gel was added before the $\mathrm{CH}_{2} \mathrm{Cl}_{2}$ was removed under reduced pressure in order to dry load the crude product onto the silica gel. The crude product was subsequently purified via silica gel column chromatography using a Hexanes to $30 \%$ $\mathrm{CH}_{2} \mathrm{Cl}_{2}$ :Hexanes gradient column. The product containing fractions were then collected and the solvent was removed under reduced pressure, affording $\mathbf{1} \mathbf{A}$ as a yellow-orange solid.

Yield: $1.3 \mathrm{~g}(56 \%)$, yellow-orange solid

${ }^{1}$ H NMR (400 MHz, THF- $\left.\boldsymbol{d}_{\mathbf{8}}\right): \delta 3.57$ (s, 4H, $\left.\mathrm{C}_{\text {carborane }}-\mathrm{H}\right), 3.3-1.3\left(\mathrm{~m}, 18 \mathrm{H}, \mathrm{B}_{\text {carborane }}-\mathrm{H}\right)$

${ }^{13} \mathbf{C}\left\{{ }^{1} \mathrm{H}\right\}$ NMR (100 MHz, THF- $\left.\boldsymbol{d}_{\mathbf{8}}\right): \delta 55.82$

${ }^{11}$ B NMR (128 MHz): $\delta-4.82(\mathrm{~s}, 1 \mathrm{~B}),-6.07\left(\mathrm{~d}, 2 \mathrm{~B},{ }^{1} \mathrm{~J}_{\mathrm{BH}}=190 \mathrm{~Hz}\right),-9.47\left(\mathrm{~d}, 1 \mathrm{~B},{ }^{1} \mathrm{~J}_{\mathrm{BH}}=155 \mathrm{~Hz}\right)$, $-12.48\left(\mathrm{~d}, 2 \mathrm{~B},{ }^{1} \mathrm{~J}_{\mathrm{BH}}=161 \mathrm{~Hz}\right),-13.71\left(\mathrm{~d}, 2 \mathrm{~B},{ }^{1} \mathrm{~J}_{\mathrm{BH}}=158 \mathrm{~Hz}\right),-17.14\left(\mathrm{~d}, 1 \mathrm{~B},{ }^{1} \mathrm{~J}_{\mathrm{BH}}=184 \mathrm{~Hz}\right),-19.68$ $\left(\mathrm{d}, 1 \mathrm{~B},{ }^{1} \mathrm{~J}_{\mathrm{BH}}=183 \mathrm{~Hz}\right)$

${ }^{77}$ Se NMR (95 MHz): $\delta-67.5\left(\mathrm{q},{ }^{1} \mathrm{~J}_{\mathrm{SeB}}=63 \mathrm{~Hz}\right)$

GC-MS $m / z: 445.20$ (calc. 445.20 )

UV-Vis (nm): 355

Elemental Analysis Calculated for $\left(\mathrm{C}_{2} \mathrm{~B}_{10} \mathrm{H}_{11} \mathrm{Se}\right)_{2}$ : $\mathrm{C}, 10.81 ; \mathrm{H}, 4.99$; found: $\mathrm{C}, 10.96 ; \mathrm{H}, 4.86$ (average of two duplicate runs, from two different batches of 1A)

\section{Synthesis of $1 B$}

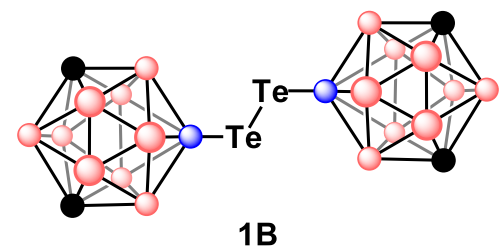

Synthetic procedures adapted from reference $5 . \mathrm{CH}_{2} \mathrm{Cl}_{2}$ used in this reaction needs to be dried thoroughly before use in order to achieve good and reproducible yields. Anhydrous $\mathrm{CH}_{2} \mathrm{Cl}_{2}(50 \mathrm{~mL})$, collected from a Grubb's column, was added to an oven-dried twoneck round bottomed flask equipped with a stir bar. $\mathrm{CaH}_{2}(\sim 1 \mathrm{~g})$ was added to the $\mathrm{CH}_{2} \mathrm{Cl}_{2}$ and stirred overnight at room temperature under $\mathrm{N}_{2}$. The following day, $\mathrm{TeCl}_{4}(2.70 \mathrm{~g}, 10 \mathrm{mmol}, 1 \mathrm{eq})$ was added to an oven-dried Schlenk flask, equipped with a stir bar and rubber septum, in an $\mathrm{N}_{2}$-filled glovebox and then transferred out. Subsequently, under a positive flow of $\mathrm{N}_{2}, \mathrm{CH}_{2} \mathrm{Cl}_{2}$ was distilled away from the $\mathrm{CaH}_{2}$ and collected in the $\mathrm{TeCl}_{4}$ - 
containing Schlenk flask. While stirring, the suspension of $\mathrm{TeCl}_{4}$ in $\mathrm{CH}_{2} \mathrm{Cl}_{2}$ was then cooled to 0 ${ }^{\circ} \mathrm{C}$ using an ice bath before the addition of Meta- $\mathrm{C}_{2} \mathrm{~B}_{10} \mathrm{H}_{12}(1.44 \mathrm{~g}, 10 \mathrm{mmol})$ and $\mathrm{AlCl}_{3}(2.66 \mathrm{~g}$, $20 \mathrm{mmol}, 2 \mathrm{eq})$. The resulting suspension was then stirred at $0{ }^{\circ} \mathrm{C}$ for an additional 30 minutes before transferring the flask to a stirring oil bath set to $45{ }^{\circ} \mathrm{C}$. The reaction progress was then monitored by TLC and the reaction was stopped once no more meta- $\mathrm{C}_{2} \mathrm{~B}_{10} \mathrm{H}_{12}$ was consumed (approx. 24 hours). After stopping the reaction, $\mathrm{CH}_{2} \mathrm{Cl}_{2}$ was removed from the Schlenk flask under reduced pressure, leaving behind a viscous, dark purple oil. Once all $\mathrm{CH}_{2} \mathrm{Cl}_{2}$ was removed, the crude material was redissolved in absolute $\mathrm{EtOH}(75 \mathrm{~mL})$, sonication will likely be required. To the resulting, dark brown, suspension, an excess of $\mathrm{Na}_{2} \mathrm{~S} \cdot 9 \mathrm{H}_{2} \mathrm{O}(4.3 \mathrm{~g})$ was added and the resulting suspension was left to stir overnight at room temperature, covered in aluminum foil to limit light exposure. After stirring overnight, the reaction mixture was then suspended in distilled $\mathrm{H}_{2} \mathrm{O}$ (750 $\mathrm{mL})$ before the addition of $\mathrm{Et}_{2} \mathrm{O}(50 \mathrm{~mL})$. The deep red organic layer was separated from the aqueous layer and the aqueous layer was extracted further with $\mathrm{Et}_{2} \mathrm{O}(3 \times 50 \mathrm{~mL})$. The organic layers were combined and dried with $\mathrm{Na}_{2} \mathrm{SO}_{4}$, resulting in a clear, dark red solution. The solution was then decanted from the $\mathrm{Na}_{2} \mathrm{SO}_{4}$, and the organic solvents were removed under reduced pressure, leaving a dark red powder. The crude product was then dissolved in $\mathrm{CH}_{2} \mathrm{Cl}_{2}$ and silica gel was added. $\mathrm{CH}_{2} \mathrm{Cl}_{2}$ was then removed under reduced pressure in order to dry load the crude product onto the silica gel. The crude product was subsequently purified via silica gel column

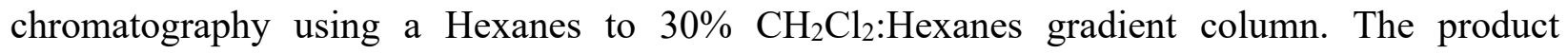
containing fractions were then collected and the solvent was removed under reduced pressure, affording $\mathbf{1 B}$ as a dark red solid.

Yield: $4.1 \mathrm{~g} \mathrm{(76 \% ),} \mathrm{dark} \mathrm{red} \mathrm{solid} \mathrm{(color} \mathrm{can} \mathrm{vary} \mathrm{between} \mathrm{hues} \mathrm{of} \mathrm{red} \mathrm{or} \mathrm{brown} \mathrm{from} \mathrm{batch} \mathrm{to}$ batch)

${ }^{1}$ H NMR (400 MHz, THF-ds): $\delta 3.61\left(\mathrm{~s}, 4 \mathrm{H}, \mathrm{C}_{\text {carborane- }} \mathrm{H}\right), 3.5-1.5\left(\mathrm{~m}, 18 \mathrm{H}, \mathrm{B}_{\text {carborane}}-\mathrm{H}\right)$

${ }^{13} \mathrm{C}\left\{{ }^{1} \mathrm{H}\right\}$ NMR (100 MHz, THF- $\left.\boldsymbol{d}_{\mathbf{8}}\right): \delta 57.83$

${ }^{11}$ B NMR (128 MHz): $\delta-5.05\left(\mathrm{~d}, 2 \mathrm{~B},{ }^{1} \mathrm{~J}_{\mathrm{BH}}=161 \mathrm{~Hz}\right),-8.21\left(\mathrm{~d}, 1 \mathrm{~B},{ }^{1} \mathrm{~J}_{\mathrm{BH}}=152 \mathrm{~Hz}\right),-11.08(\mathrm{~d}, 2 \mathrm{~B}$, $\left.{ }^{1} \mathrm{~J}_{\mathrm{BH}}=203 \mathrm{~Hz}\right),-12.72\left(\mathrm{~d}, 2 \mathrm{~B},{ }^{1} \mathrm{~J}_{\mathrm{BH}}=174 \mathrm{~Hz}\right),-16.23\left(\mathrm{~d}, 1 \mathrm{~B},{ }^{1} \mathrm{~J}_{\mathrm{BH}}=181 \mathrm{~Hz}\right),-17.72\left(\mathrm{~d}, 1 \mathrm{~B},{ }^{1} \mathrm{~J}_{\mathrm{BH}}\right.$ $=186 \mathrm{~Hz}),-22.12(\mathrm{~s}, 1 \mathrm{~B})$

${ }^{125}$ Te NMR (158 MHz): $\delta-341.8\left(\mathrm{q},{ }^{1} \mathrm{~J}_{\mathrm{TeB}}=207 \mathrm{~Hz}\right)$

GC-MS $m / z: 542.20$ (calc. 542.18 )

UV-Vis (nm): 295, 417

Elemental Analysis Calculated for $\left(\mathrm{C}_{2} \mathrm{~B}_{10} \mathrm{H}_{11} \mathrm{Te}\right)_{2}$ : C, 8.87; H, 4.09; found: C, 9.34; H, 4.16 (average of two duplicate runs)

\section{Synthesis of Electrophilic Reagents (2A, 3A, 4A)}

\section{Synthesis of $2 A$}


Synthetic procedures adapted from reference 4. 1A (223 mg, $0.5 \mathrm{mmol} ; 1 \mathrm{eq})$ was added to an oven dried Schlenk flask equipped with a stir bar and rubber septum. The reaction tube was evacuated and backfilled with $\mathrm{N}_{2}$ three times before adding $5 \mathrm{~mL}$ of anhydrous $\mathrm{CH}_{2} \mathrm{Cl}_{2}$ via syringe. The resulting suspension was allowed to stir and the reaction tube was immersed in an ice bath to cool the solution to $0{ }^{\circ} \mathrm{C}$. Subsequently, $\mathrm{SO}_{2} \mathrm{Cl}_{2}(81 \mu \mathrm{L}, 0.5 \mathrm{mmol}, 1 \mathrm{eq})$ was added to the stirring solution of $\mathbf{1 A}$ by micropipette, and the reaction was left to stir for 30 minutes at $0{ }^{\circ} \mathrm{C}$. After 30 minutes, the solvent was removed from the reaction flask via the high-vacuum line on the Schlenk line and dried to completion. The remaining burnt orange solid was collected from the Schlenk flask and used as is.

Yield: $241 \mathrm{mg}(94 \%)$, burnt orange solid

${ }^{1}$ H NMR (400 MHz, CDCl 3 ): $\delta 3.75$ (s, 2H, C carborane-H), 3.5-1.5 (m, 9H, B carborane-H)

${ }^{13} \mathrm{C}\left\{{ }^{1} \mathrm{H}\right\}$ NMR (100 MHz, $\left.\mathrm{CDCl}_{3}\right): \delta 56.32$

${ }^{11}$ B NMR (128 MHz): $\delta-3.74(\mathrm{~s}, 1 \mathrm{~B}),-6.34\left(\mathrm{~d}, 2 \mathrm{~B},{ }^{1} \mathrm{~J}_{\mathrm{BH}}=171 \mathrm{~Hz}\right),-9.97\left(\mathrm{~d}, 1 \mathrm{~B},{ }^{1} \mathrm{~J}_{\mathrm{BH}}=155 \mathrm{~Hz}\right)$, $-12.85\left(\mathrm{~d}, 2 \mathrm{~B},{ }^{1} \mathrm{~J}_{\mathrm{BH}}=165 \mathrm{~Hz}\right),-13.34\left(\mathrm{~d}, 2 \mathrm{~B},{ }^{1} \mathrm{~J}_{\mathrm{BH}}=165 \mathrm{~Hz}\right),-16.73\left(\mathrm{~d}, 1 \mathrm{~B},{ }^{1} \mathrm{~J}_{\mathrm{BH}}=184 \mathrm{~Hz}\right),-18.20$ $\left(\mathrm{d}, 1 \mathrm{~B},{ }^{1} \mathrm{~J}_{\mathrm{BH}}=188 \mathrm{~Hz}\right)$

${ }^{77}$ Se NMR (95 MHz): $\delta 808.4(\mathrm{~m})$

\section{Synthesis of 3A}

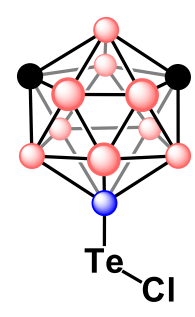

3A

Synthetic procedures adapted from reference 5. Prepared in an analogous method to $\mathbf{2 A}$, where $\mathbf{1 B}$ was used instead of $\mathbf{1 A}$.

Yield: $300 \mathrm{mg}$ (quantitative), burgundy solid

${ }^{1}$ H NMR (400 MHz, THF-ds): $\delta 3.86$ (s, 2H, C carborane-H) ) 3.5-1.5 (m, 9H, B carborane- $^{-}$ $\mathrm{H)}$

${ }^{13} \mathrm{C}\left\{{ }^{1} \mathrm{H}\right\}$ NMR (100 MHz, THF-ds): $\delta 57.12$

${ }^{11}$ B NMR (128 MHz): $\delta 2.80(\mathrm{~s}, 1 \mathrm{~B}),-6.20\left(\mathrm{~d}, 2 \mathrm{~B},{ }^{1} \mathrm{~J}_{\mathrm{BH}}=161 \mathrm{~Hz}\right),-9.68\left(\mathrm{~d}, 1 \mathrm{~B},{ }^{1} \mathrm{~J}_{\mathrm{BH}}=161 \mathrm{~Hz}\right)$, $-12.57\left(\mathrm{~d}, 2 \mathrm{~B},{ }^{1} \mathrm{~J}_{\mathrm{BH}}=161 \mathrm{~Hz}\right),-13.00\left(\mathrm{~d}, 2 \mathrm{~B},{ }^{1} \mathrm{~J}_{\mathrm{BH}}=165 \mathrm{~Hz}\right),-16.48\left(\mathrm{~d}, 2 \mathrm{~B},{ }^{1} \mathrm{~J}_{\mathrm{BH}}=184 \mathrm{~Hz}\right)$

${ }^{125}$ Te NMR (158 MHz): $\delta 1382.9$ (m)

\section{Synthesis of $4 \mathrm{~A}$}

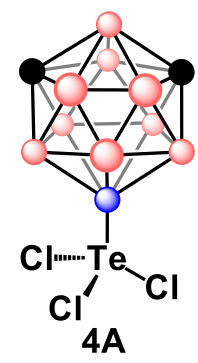

Synthetic procedures modified from reference 5. 1B (163 mg, $0.3 \mathrm{mmol}$; $1 \mathrm{eq})$ was added to an oven dried reaction tube equipped with a stir bar and PTFE cap. The reaction tube was evacuated and backfilled with $\mathrm{N}_{2}$ three times before adding $5 \mathrm{~mL}$ of anhydrous $\mathrm{CH}_{2} \mathrm{Cl}_{2}$ via syringe. The resulting suspension was allowed to stir and the reaction tube was immersed in an ice bath to cool the solution to $0{ }^{\circ} \mathrm{C}$. Subsequently, $\mathrm{SO}_{2} \mathrm{Cl}_{2}(121 \mu \mathrm{L}, 1.5 \mathrm{mmol}, 5 \mathrm{eq})$ was added by micropipette to the stirring solution of $\mathbf{1 B}$, and the reaction was left to stir for 30 minutes at $0{ }^{\circ} \mathrm{C}$. After 30 minutes, the now cloudy white reaction mixture was centrifuged and the supernatant was 
carefully decanted. The remaining white solid was washed with hexanes $(3 \times 5 \mathrm{~mL})$ and dried in vacuo to yield a free-flowing white powder.

Yield: $192 \mathrm{mg}(85 \%)$, white solid

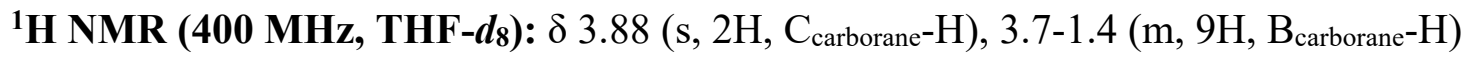

${ }^{13} \mathrm{C}\left\{{ }^{1} \mathrm{H}\right\}$ NMR (100 MHz, THF-d8): $\delta 57.09$

${ }^{11}$ B NMR (128 MHz): $\delta 3.13(\mathrm{~s}, 1 \mathrm{~B}),-5.96\left(\mathrm{~d}, 2 \mathrm{~B},{ }^{1} \mathrm{~J}_{\mathrm{BH}}=168 \mathrm{~Hz}\right),-9.43\left(\mathrm{~d}, 1 \mathrm{~B},{ }^{1} \mathrm{~J}_{\mathrm{BH}}=153 \mathrm{~Hz}\right)$, $-12.25\left(\mathrm{~d}, 2 \mathrm{~B},{ }^{1} \mathrm{~J}_{\mathrm{BH}}=153 \mathrm{~Hz}\right),-12.79\left(\mathrm{~d}, 2 \mathrm{~B},{ }^{1} \mathrm{~J}_{\mathrm{BH}}=158 \mathrm{~Hz}\right),-16.25\left(\mathrm{~d}, 2 \mathrm{~B},{ }^{1} \mathrm{~J}_{\mathrm{BH}}=178 \mathrm{~Hz}\right)$

${ }^{125}$ Te NMR (158 MHz): $\delta 1376(\mathrm{~m})$

\section{Reactions of Selenyl (II) Chloride (2A)}

a. Synthesis of $2 B$

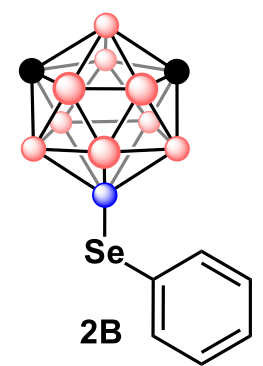

2A (39 $\mathrm{mg}, 0.15 \mathrm{mmol}, 1 \mathrm{eq}$ ) was added to an oven dried reaction tube equipped with a stir bar and PTFE cap. The reaction tube was evacuated and backfilled with $\mathrm{N}_{2}$ three times before adding $\sim 1 \mathrm{~mL}$ of anhydrous $\mathrm{Et}_{2} \mathrm{O}$ via cannula transfer to the tube. The resulting solution was allowed to stir for 5 minutes to ensure all solids had dissolved. Subsequently, a solution of phenylmagnesium bromide $(0.15 \mathrm{~mL}$, $3 \mathrm{M}, 0.45 \mathrm{mmol}, 3 \mathrm{eq}$ ) was added dropwise to the stirring solution of $\mathbf{2 A}$ (caution: heat is evolved during the addition of the Grignard reagent). Once the addition of the Grignard reagent was complete, the reaction was left to stir for $16 \mathrm{~h}$ at room temperature. After $16 \mathrm{~h}$, the reaction was quenched by the careful addition of $\mathrm{H}_{2} \mathrm{O}(5 \mathrm{~mL})$. The quenched reaction mixture was then extracted with $\mathrm{Et}_{2} \mathrm{O}(2 \times 5 \mathrm{~mL})$ and the combined organic layers were dried with $\mathrm{Na}_{2} \mathrm{SO}_{4}$ before passing the solution through a silica plug and eluting with $\mathrm{Et}_{2} \mathrm{O}$. The solvent was then removed under reduced pressure to yield a white solid.

Yield: $41 \mathrm{mg}(91 \%)$, white solid

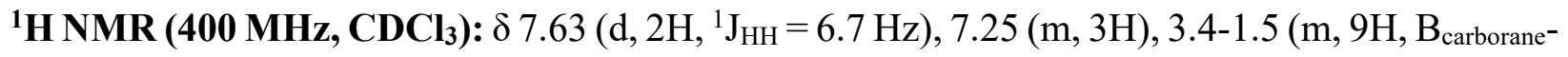
$\mathrm{H}), 2.95$ (s, 2H, C carborane-H)

${ }^{13} \mathbf{C}\left\{{ }^{1} \mathbf{H}\right\}$ NMR (100 MHz, $\left.\mathbf{C D C l}_{3}\right): \delta 136.38,128.97,128.75,127.20,55.16$

${ }^{11}$ B NMR (128 MHz): $\delta-4.09$ (s, 1B), -6.39 (d, 2B, $\left.{ }^{1} \mathrm{~J}_{\mathrm{BH}}=165 \mathrm{~Hz}\right),-9.52\left(\mathrm{~d}, 1 \mathrm{~B},{ }^{1} \mathrm{~J}_{\mathrm{BH}}=152 \mathrm{~Hz}\right)$, $-13.02\left(\mathrm{~d}, 2 \mathrm{~B},{ }^{1} \mathrm{~J}_{\mathrm{BH}}=165 \mathrm{~Hz}\right),-13.59\left(\mathrm{~d}, 2 \mathrm{~B},{ }^{1} \mathrm{~J}_{\mathrm{BH}}=169 \mathrm{~Hz}\right),-17.28\left(\mathrm{~d}, 1 \mathrm{~B},{ }^{1} \mathrm{~J}_{\mathrm{BH}}=183 \mathrm{~Hz}\right),-19.60$ $\left(\mathrm{d}, 1 \mathrm{~B},{ }^{1} \mathrm{~J}_{\mathrm{BH}}=183 \mathrm{~Hz}\right)$

${ }^{77}$ Se NMR (95 MHz): $\delta 79.8\left(\mathrm{q},{ }^{1} \mathrm{~J}_{\mathrm{SeB}}=45 \mathrm{~Hz}\right)$

GC-MS $m / z: 299.20$ (calc. 299.15)

\section{b. General procedure for compounds $2 \mathrm{C}-2 \mathrm{E}$}

2A (39 mg, $0.15 \mathrm{mmol}, 1 \mathrm{eq}$ ) was added to a reaction tube equipped with a stir bar and PTFE cap before the addition of anhydrous $\mathrm{CH}_{2} \mathrm{Cl}_{2}$ via syringe. The resulting mixture was then stirred for several minutes, forming a clear orange solution. Substrate $(0.15 \mathrm{mmol}, 1 \mathrm{eq})$ was then added to 
the stirring solution at room temperature, and left to stir overnight. Over time, the reaction solution was observed to become clear and colorless/pale yellow, indicating the consumption of the starting material, 2A. After stirring the reaction overnight at room temperature, the crude reaction mixture was subsequently dry loaded onto silica and then purified via silica gel column chromatography. See individual entries for specific isolation procedures.

\section{Characterization of $2 \mathrm{C}$}

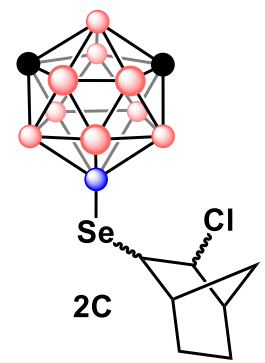

Isolation: Hexanes to $20 \% \mathrm{CH}_{2} \mathrm{Cl}_{2}:$ Hexanes gradient

Yield: $25 \mathrm{mg}$ (47\%), white solid

${ }^{1}$ H NMR (400 MHz, CDCl $): \delta 4.08(\mathrm{~m}, 1 \mathrm{H}), 3.4-1.5\left(\mathrm{~m}, 9 \mathrm{H}, \mathrm{B}_{\text {carborane }}-\mathrm{H}\right), 3.02$ $\left(\mathrm{s}, 2 \mathrm{H}, \mathrm{C}_{\text {carborane }}-\mathrm{H}\right), 2.75(\mathrm{~s}, 1 \mathrm{H}), 2.37(\mathrm{~m}, 2 \mathrm{H}), 1.96(\mathrm{~m}, 1 \mathrm{H}), 1.80\left(\mathrm{~d}, 1 \mathrm{H},{ }^{1} \mathrm{~J}_{\mathrm{HH}}=\right.$ $10.8 \mathrm{~Hz}), 1.67(\mathrm{~m}, 1 \mathrm{H}), 1.41(\mathrm{~m}, 3 \mathrm{H})$

${ }^{13} \mathbf{C}\left\{{ }^{1} \mathbf{H}\right\}$ NMR (100 MHz, $\left.\mathbf{C D C l}_{3}\right): \delta$ 70.23, 55.32, 51.43, 46.51, 44.39, 35.94,

$29.56,21.43$

${ }^{11}$ B NMR (128 MHz): $\delta-5.08$ (s, 1B), $-6.38\left(\mathrm{~d}, 2 \mathrm{~B},{ }^{1} \mathrm{~J}_{\mathrm{BH}}=183 \mathrm{~Hz}\right),-9.57\left(\mathrm{~d}, 1 \mathrm{~B},{ }^{1} \mathrm{~J}_{\mathrm{BH}}=152 \mathrm{~Hz}\right)$, $-13.04\left(\mathrm{~d}, 2 \mathrm{~B},{ }^{1} \mathrm{~J}_{\mathrm{BH}}=161 \mathrm{~Hz}\right),-13.56\left(\mathrm{~d}, 2 \mathrm{~B},{ }^{1} \mathrm{~J}_{\mathrm{BH}}=165 \mathrm{~Hz}\right),-17.30\left(\mathrm{~d}, 1 \mathrm{~B},{ }^{1} \mathrm{~J}_{\mathrm{BH}}=183 \mathrm{~Hz}\right),-19.47$ $\left(\mathrm{d}, 1 \mathrm{~B},{ }^{1} \mathrm{~J}_{\mathrm{BH}}=184 \mathrm{~Hz}\right)$

${ }^{77}$ Se NMR (95 MHz): $\delta 57.2(\mathrm{~m})$

GC-MS $m / z: 352.20$ (calc. 352.15 )

\section{Characterization of 2D}

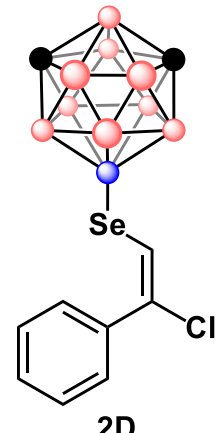

2D

Isolation: Hexanes to $15 \% \mathrm{CH}_{2} \mathrm{Cl}_{2}$ :Hexanes gradient

Yield: $29 \mathrm{mg}$ (54\%), white solid

${ }^{1} \mathbf{H}$ NMR (400 MHz, $\left.\mathbf{C D C l}_{3}\right): \delta 7.61\left(\mathrm{dd}, 2 \mathrm{H},{ }^{1} \mathrm{~J}_{\mathrm{HH}}=8.5 \mathrm{~Hz}, 1.4 \mathrm{~Hz}\right), 7.35(\mathrm{~m}, 3 \mathrm{H})$, $6.84(\mathrm{~m}, \mathrm{~b}, 1 \mathrm{H}), 3.5-1.6\left(\mathrm{~m}, 9 \mathrm{H}, \mathrm{B}_{\text {carborane }}-\mathrm{H}\right), 3.06\left(\mathrm{~s}, 2 \mathrm{H}, \mathrm{C}_{\text {carborane }}-\mathrm{H}\right)$

${ }^{13} \mathbf{C}\left\{{ }^{1} \mathbf{H}\right\}$ NMR (100 MHz, $\left.\mathbf{C D C l}_{3}\right): \delta 137.47,128.70,128.65,128.10,126.81$, $117.47,55.49$

$\left.{ }^{1} \mathrm{~J}_{\mathrm{BH}}=149 \mathrm{~Hz}\right),-13.47\left(\mathrm{~d}, 4 \mathrm{~B},{ }^{1} \mathrm{~J}_{\mathrm{BH}}=168 \mathrm{~Hz}\right),-17.27\left(\mathrm{~d}, 1 \mathrm{~B},{ }^{1} \mathrm{~J}_{\mathrm{BH}}=184 \mathrm{~Hz}\right),-19.20\left(\mathrm{~d}, 1 \mathrm{~B},{ }^{1} \mathrm{~J}_{\mathrm{BH}}\right.$ $=196 \mathrm{~Hz})$

${ }^{77}$ Se NMR (95 MHz): $\delta 58.2\left(\mathrm{q},{ }^{1} \mathrm{~J}_{\mathrm{SeB}}=37 \mathrm{~Hz}\right)$

GC-MS $m / z: 360.20$ (calc. 360.12 )

\section{Characterization of $2 E$}




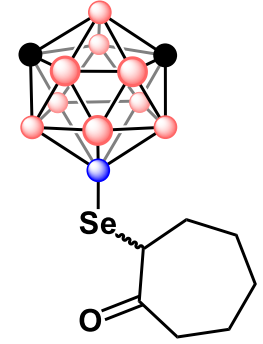

2E

Isolation: Hexanes to $\mathrm{CH}_{2} \mathrm{Cl}_{2}$ gradient

Yield: $27 \mathrm{mg}$ (54\%), white solid

${ }^{1}$ H NMR (400 MHz, CDCl 3$): \delta 3.58(\mathrm{~m}, 1 \mathrm{H}), 3.4-1.1\left(\mathrm{~m}, 9 \mathrm{H}, \mathrm{B}_{\text {carborane-H) }}\right.$ ) 3.01 $\left(\mathrm{s}, 2 \mathrm{H}, \mathrm{C}_{\text {carborane }} \mathrm{H}\right), 2.80(\mathrm{~m}, 1 \mathrm{H}), 2.38(\mathrm{~m}, 1 \mathrm{H}), 2.27(\mathrm{~m}, 1 \mathrm{H}), 1.90(\mathrm{~m}, 2 \mathrm{H}), 1.68$ $(\mathrm{m}, 2 \mathrm{H}), 1.47(\mathrm{~m}, 2 \mathrm{H}), 1.27(\mathrm{~m}, 1 \mathrm{H})$

${ }^{13} \mathbf{C}\left\{{ }^{1} \mathbf{H}\right\}$ NMR (100 MHz, $\left.\mathbf{C D C l}_{3}\right): \delta 210.17,55.30,47.88,39.75,33.19,30.13$, $27.84,25.61$

${ }^{11}$ B NMR (128 MHz): $\delta-4.90$ (s, 1B), -5.93 (d, 2B, $\left.{ }^{1} \mathrm{~J}_{\mathrm{BH}}=202 \mathrm{~Hz}\right),-9.19\left(\mathrm{~d}, 1 \mathrm{~B},{ }^{1} \mathrm{~J}_{\mathrm{BH}}=153 \mathrm{~Hz}\right)$, $-13.14\left(\mathrm{~d}, 4 \mathrm{~B},{ }^{1} \mathrm{~J}_{\mathrm{BH}}=165 \mathrm{~Hz}\right),-16.84\left(\mathrm{~d}, 1 \mathrm{~B},{ }^{1} \mathrm{~J}_{\mathrm{BH}}=186 \mathrm{~Hz}\right),-18.86\left(\mathrm{~d}, 1 \mathrm{~B},{ }^{1} \mathrm{~J}_{\mathrm{BH}}=193 \mathrm{~Hz}\right)$

${ }^{77}$ Se NMR (95 MHz): $\delta 50.2\left(\mathrm{q},{ }^{1} \mathrm{~J}_{\mathrm{SeB}}=44 \mathrm{~Hz}\right)$

GC-MS $m / z: 334.20$ (calc. 334.18 )

\section{c. Synthesis of $2 \mathrm{~F}$}

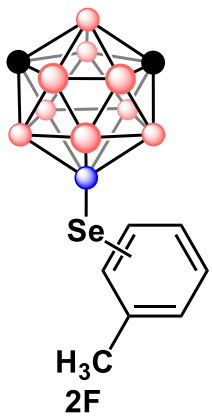

$\mathbf{2 A}(117 \mathrm{mg}, 0.45 \mathrm{mmol}, 1 \mathrm{eq})$ and $\mathrm{AlCl}_{3}(120 \mathrm{mg}, 0.90 \mathrm{mmol}, 2 \mathrm{eq})$ were added to a reaction tube equipped with a stir bar and PTFE cap before the addition of anhydrous toluene ( $1.5 \mathrm{~mL}$, excess) via syringe. The resulting dark red mixture was then stirred for several minutes at room temperature, before immersing the reaction tube in a preheated oil bath set to $50{ }^{\circ} \mathrm{C}$. The reaction was then left to stir for $16 \mathrm{~h}$. After $16 \mathrm{~h}$, the reaction tube was removed from the oil bath and allowed to cool to room temperature. Once cooled, distilled $\mathrm{H}_{2} \mathrm{O}(10 \mathrm{~mL})$ was carefully added to quench the remaining $\mathrm{AlCl}_{3}$. The resulting biphasic mixture was then extracted with $\mathrm{CH}_{2} \mathrm{Cl}_{2}(3 \times 5 \mathrm{~mL})$ and the collected organic layers were dried over $\mathrm{Na}_{2} \mathrm{SO}_{4}$. The product-containing solution was decanted away, and the solvent was removed under reduced pressure, leaving the crude product as a red oil. The crude product was then purified via silica gel column chromatography with a Hexanes to $10 \% \mathrm{CH}_{2} \mathrm{Cl}_{2}$ :Hexanes gradient. The productcontaining fractions were collected and volatiles were removed under reduced pressure, affording the product as a yellow-orange oil in $21 \%$ isolated yield.

Yield: $30 \mathrm{mg}(21 \%)$, pale yellow solid

${ }^{1}$ H NMR (400 MHz, CDCl 3$): \delta$ 7.73-6.87 (m, 4H), 3.4-1.6 (m, 9H, B carborane-H), 2.94 (s, 2H, $\mathrm{C}_{\text {carborane-H}}$ ), $2.31(\mathrm{~s}, 3 \mathrm{H})$

${ }^{13} \mathbf{C}\left\{{ }^{1} \mathbf{H}\right\}$ NMR (100 MHz, $\left.\mathbf{C D C l}_{3}\right): \delta$ 138.32-125.28, 55.11, 23.94-21.17

${ }^{11}$ B NMR (128 MHz): $\delta-4.06$ (s, 1B), -6.43 (d, 2B, $\left.{ }^{1} \mathrm{~J}_{\mathrm{BH}}=161 \mathrm{~Hz}\right),-9.54\left(\mathrm{~d}, 1 \mathrm{~B},{ }^{1} \mathrm{~J}_{\mathrm{BH}}=152 \mathrm{~Hz}\right)$, $-13.05\left(\mathrm{~d}, 2 \mathrm{~B},{ }^{1} \mathrm{~J}_{\mathrm{BH}}=161 \mathrm{~Hz}\right),-13.65\left(\mathrm{~d}, 2 \mathrm{~B},{ }^{1} \mathrm{~J}_{\mathrm{BH}}=161 \mathrm{~Hz}\right),-17.33\left(\mathrm{~d}, 1 \mathrm{~B},{ }^{1} \mathrm{~J}_{\mathrm{BH}}=180 \mathrm{~Hz}\right),-19.69$ $\left(\mathrm{d}, 1 \mathrm{~B},{ }^{1} \mathrm{~J}_{\mathrm{BH}}=183 \mathrm{~Hz}\right)$

${ }^{77}$ Se NMR (95 MHz): $\delta 79.4(\mathrm{~m})$

GC-MS $m / z: 314.20$ (calc. 314.16 ) 


\section{d. Comparison of High and Low-Field (400-600 MHz) ${ }^{1} \mathrm{H}$ NMR Spectroscopy of $2 \mathrm{C}$}

High-Field ${ }^{1} \mathrm{H}$ NMR spectroscopy was used in attempt to resolve ${ }^{1} \mathrm{H}$ resonances in the alkyl region that could be correlated to the four expected norbornyl selenide isomers present in the purified reaction mixture. However, even using the higher field spectrometer, the ${ }^{1} \mathrm{H}$ resonances are not sufficiently resolved to assign. See stacked spectra below, including inset. Top spectrum was obtained on a $400 \mathrm{MHz}$ NMR spectrometer, while the bottom spectrum was obtained on a $600 \mathrm{MHz}$ NMR spectrometer. NMR samples were obtained from two separate batches of $\mathbf{2 C}$ with slight variances in purity.
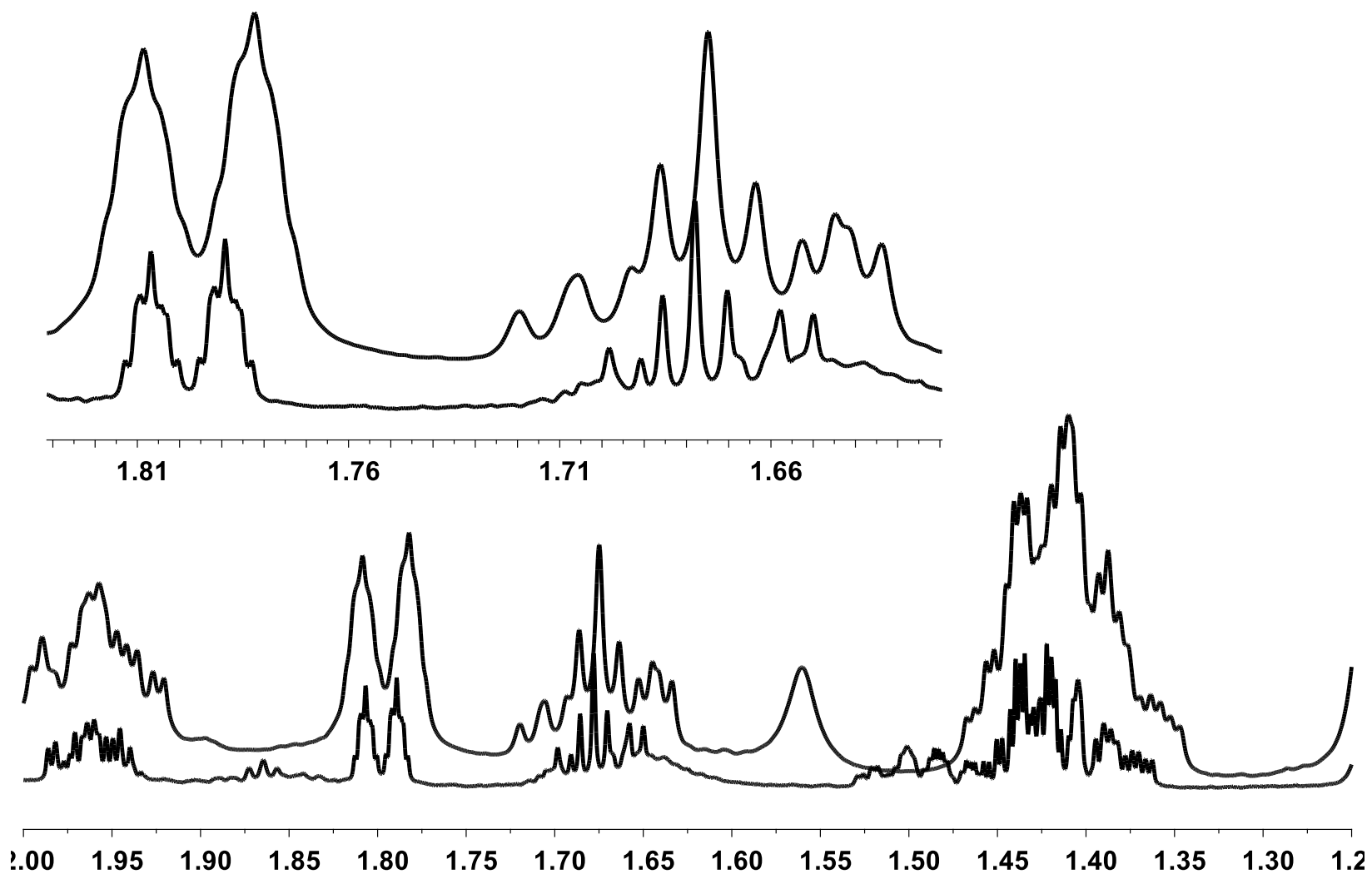

e. GC-MS Trace of Isolated 2C and 2C' Mixture

Included below is a $\mathrm{GC}-\mathrm{MS}$ trace of purified $2 \mathrm{C}$ and $2 \mathrm{C}^{\prime}$, indicating an approximate isomer distribution of 70:30 from compounds with retention times of 2.5 and 2.6 minutes. 


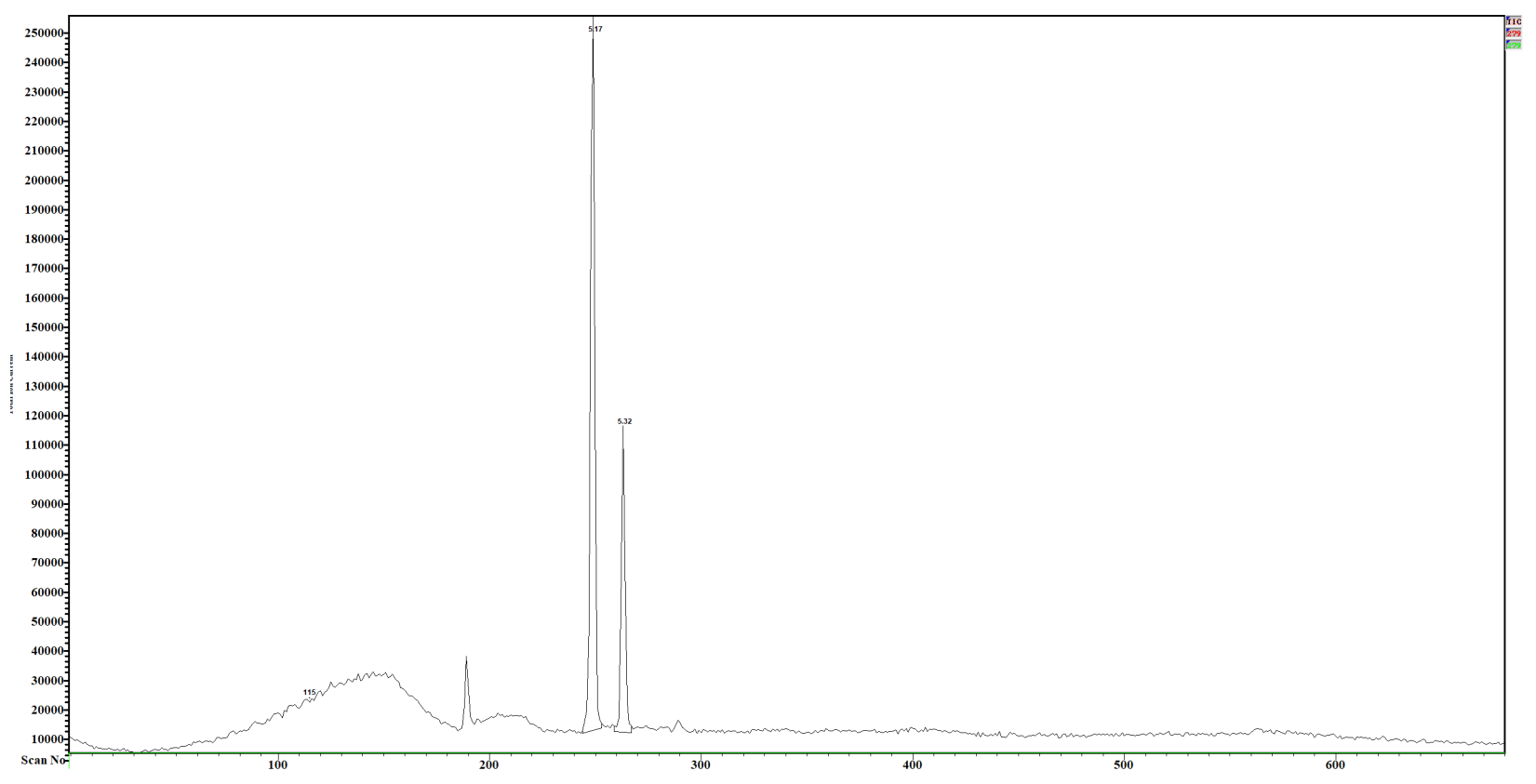

\section{f. GC-MS Trace of Isolated 2F}

Included below is a GC-MS trace of purified $2 \mathrm{~F}$, indicating an approximate $o / m: p$ isomer distribution of 19:81.

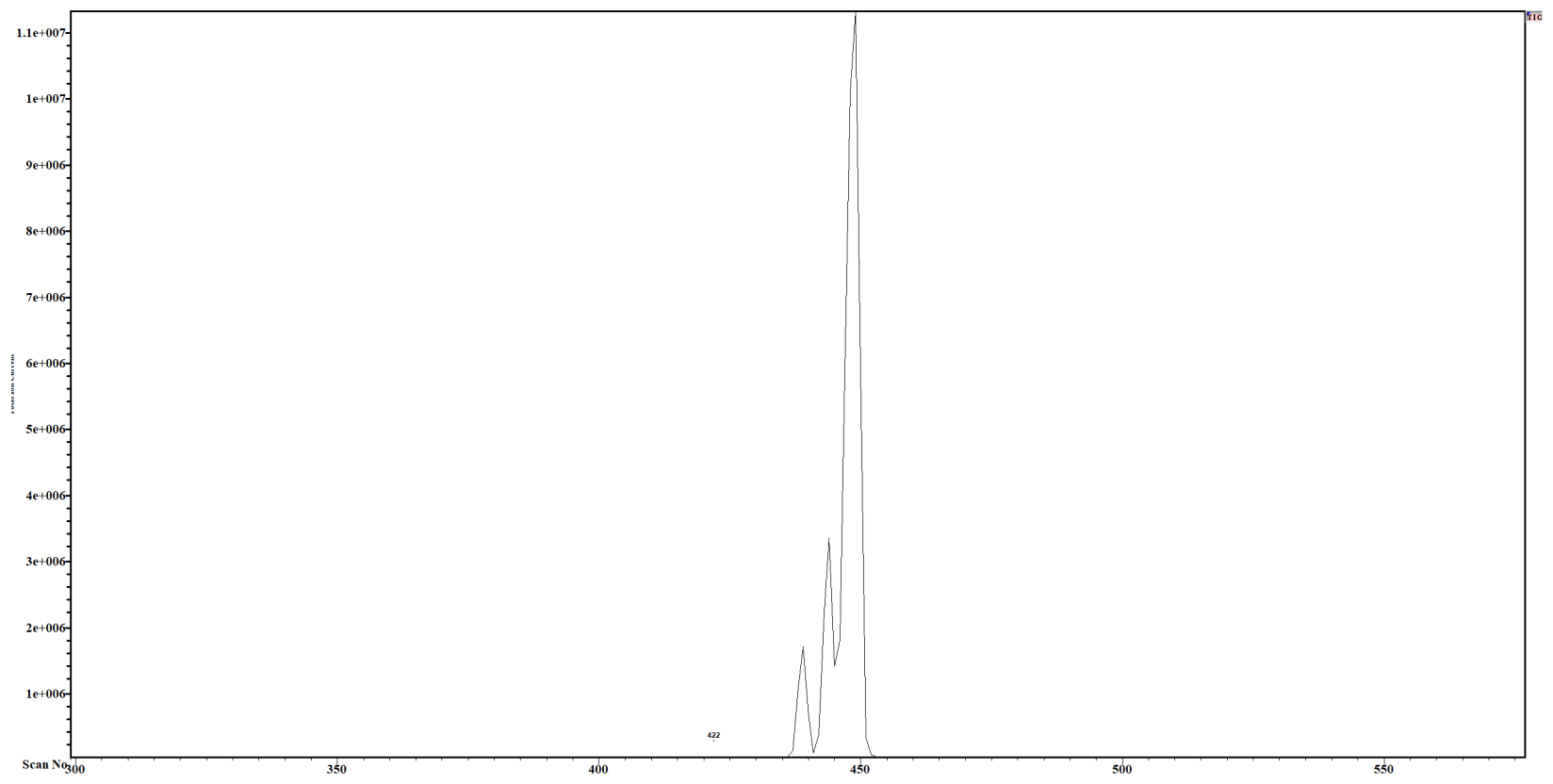

\section{g. Experiments with Perdeuterated Toluene}

Experiments with perdeuterated toluene were performed to obtain a more accurate distribution of ortho-, meta-, and para-tolyl selenide isomers. The deutero-tolyl selenide was prepared following analogous reaction conditions used in the synthesis of $\mathbf{2 F}$, where toluene was replaced with perdeuterated toluene. From ${ }^{2} \mathrm{H}$ NMR spectroscopy (see below), the $\mathrm{CD}_{3}$ 
resonances for each isomer are clearly resolved from 2.50-2.30 ppm. Integrations of those resonances indicate an approximate distribution of: 11:89, o/m:p.

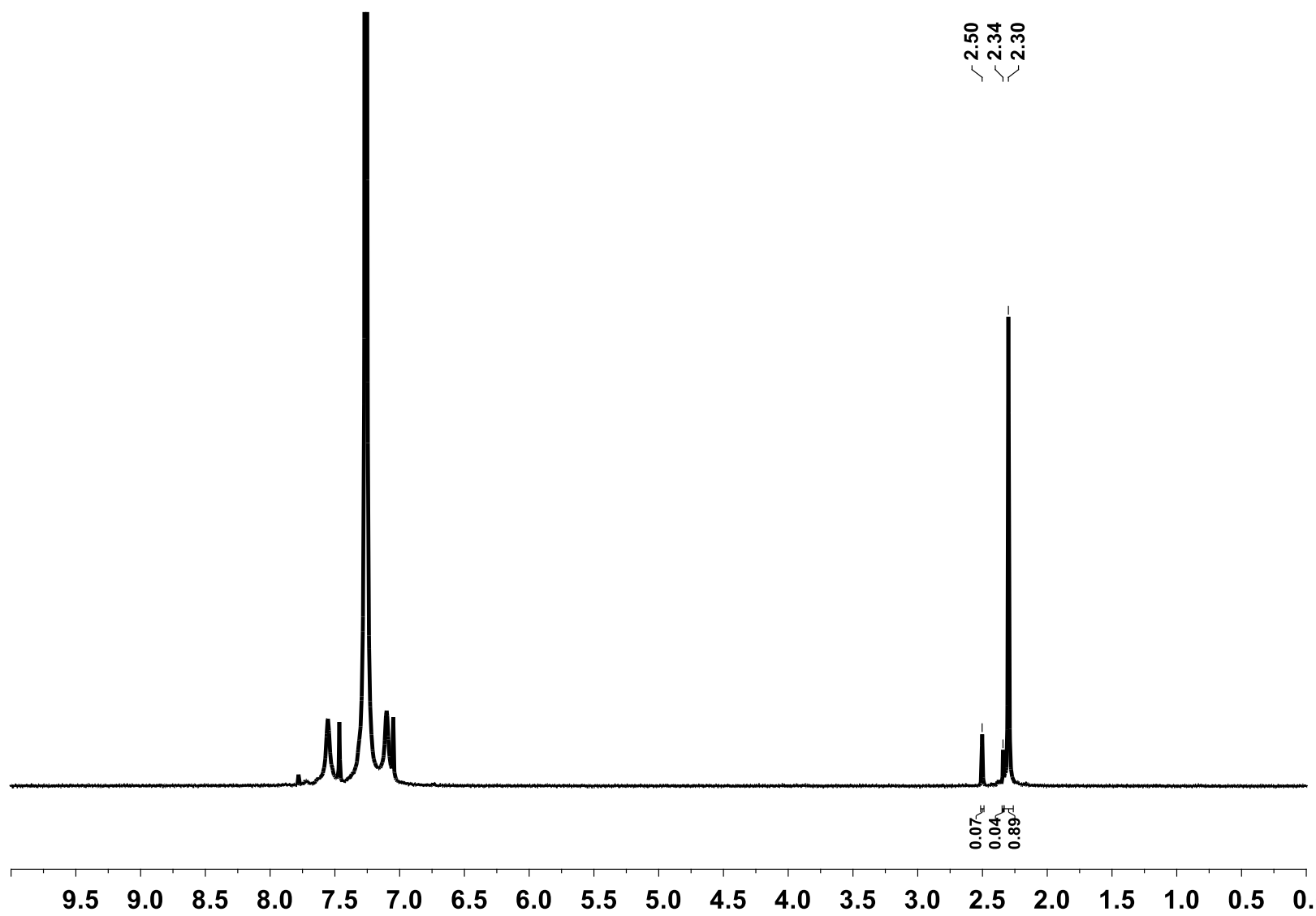

\section{Reactions of Tellurenyl (II) Chloride (3A)}

a. Synthesis of 3B

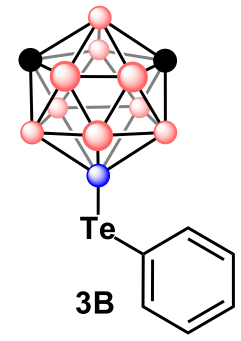

3A (45 mg, $0.15 \mathrm{mmol}, 1 \mathrm{eq}$ ) was added to an oven dried reaction tube equipped with a stir bar and PTFE cap. The reaction tube was evacuated and backfilled with $\mathrm{N}_{2}$ three times before adding $\sim 1 \mathrm{~mL}$ of anhydrous $\mathrm{Et}_{2} \mathrm{O}$ via cannula transfer to the tube. Subsequently, a solution of phenylmagnesium bromide $(0.15 \mathrm{~mL}, 3 \mathrm{M}, 0.45$ mmol, 3 eq) was added dropwise to the stirring suspension of $\mathbf{3 A}$ (caution: heat is evolved during the addition of the Grignard reagent). Once the addition of the Grignard reagent was complete, the reaction was left to stir for $16 \mathrm{~h}$ at room temperature. After $16 \mathrm{~h}$, the reaction was quenched by the careful addition of $\mathrm{H}_{2} \mathrm{O}(5 \mathrm{~mL})$. The quenched reaction mixture was then extracted with $\mathrm{Et}_{2} \mathrm{O}(2 \times 5 \mathrm{~mL})$ and the combined organic layers were dried with $\mathrm{Na}_{2} \mathrm{SO}_{4}$ before passing the solution through a silica plug and eluting with $\mathrm{Et}_{2} \mathrm{O}$. The solvent was then removed under reduced pressure to yield a white solid.

Yield: $39 \mathrm{mg}(75 \%)$, white solid

${ }^{1} \mathbf{H}$ NMR (400 MHz, CDCl 3 ): $\delta 7.82\left(\mathrm{~d}, 2 \mathrm{H},{ }^{1} \mathrm{~J}_{\mathrm{HH}}=6.8 \mathrm{~Hz}\right), 7.29\left(\mathrm{t}, 1 \mathrm{H},{ }^{1} \mathrm{~J}_{\mathrm{HH}}=7.4 \mathrm{~Hz}\right), 7.14(\mathrm{t}$, $\left.2 \mathrm{H},{ }^{1} \mathrm{~J}_{\mathrm{HH}}=7.6 \mathrm{~Hz}\right), 3.6-1.5\left(\mathrm{~m}, 9 \mathrm{H}, \mathrm{B}_{\text {carborane }}-\mathrm{H}\right), 3.01\left(\mathrm{~s}, 2 \mathrm{H}, \mathrm{C}_{\text {carborane }}-\mathrm{H}\right)$ 
${ }^{13} \mathbf{C}\left\{{ }^{1} \mathbf{H}\right\}$ NMR (100 MHz, CDCl $): \delta$ 140.80, 128.79, 127.46, 108.71, 57.00

${ }^{11}$ B NMR (128 MHz): $\delta-5.82\left(\mathrm{~d}, 2 \mathrm{~B},{ }^{1} \mathrm{~J}_{\mathrm{BH}}=168 \mathrm{~Hz}\right),-8.87\left(\mathrm{~d}, 1 \mathrm{~B},{ }^{1} \mathrm{~J}_{\mathrm{BH}}=155 \mathrm{~Hz}\right),-12.70(\mathrm{~d}, 4 \mathrm{~B}$, $\left.{ }^{1} \mathrm{~J}_{\mathrm{BH}}=166 \mathrm{~Hz}\right),-15.79(\mathrm{~s}, 1 \mathrm{~B}),-16.92(\mathrm{~m}, 2 \mathrm{~B})$

${ }^{125}$ Te NMR (158 MHz): $\delta 66.9\left(\mathrm{q},{ }^{1} \mathrm{~J}_{\mathrm{TeB}}=159 \mathrm{~Hz}\right)$

GC-MS $m / z: 349.20$ (calc. 349.13 )

\section{b. Reaction of 3A with Phenylacetylene in Dichloromethane}

3A (45 mg, $0.15 \mathrm{mmol}, 1 \mathrm{eq}$ ) was added to an oven dried reaction tube equipped with a stir bar and PTFE cap before the reaction tube was evacuated and backfilled with $\mathrm{N}_{2}$ three times. $\mathrm{CH}_{2} \mathrm{Cl}_{2}$ $(1 \mathrm{~mL})$ and phenylacetylene $(16.5 \mu \mathrm{L}, 0.15 \mathrm{mmol}, 1 \mathrm{eq})$ were then added to the reaction tube under a positive flow of $\mathrm{N}_{2}$, and the reaction tube was then sealed. The resulting mixture was then left to stir for $8 \mathrm{~h}$ at room temperature. After stirring for $8 \mathrm{~h}$, the $\mathrm{CH}_{2} \mathrm{Cl}_{2}$ was removed from the vial under high vacuum and redissolved in THF. The resulting solution was then transferred to an NMR tube for in situ ${ }^{11} \mathrm{~B}$ NMR spectroscopy to determine conversion to the desired product. The in situ ${ }^{11} \mathrm{~B}$ NMR is included below. The ${ }^{11} \mathrm{~B}$ NMR spectrum reveals that the mixture is largely comprised of starting material and ditelluride (1B). Red highlight indicates ${ }^{11} \mathrm{~B}$ resonance associated with starting material. Blue highlight indicated ${ }^{11} \mathrm{~B}$ resonance associated with $\mathbf{1 B}$. Green highlight indicates the expected chemical shift for the desired telluride product.

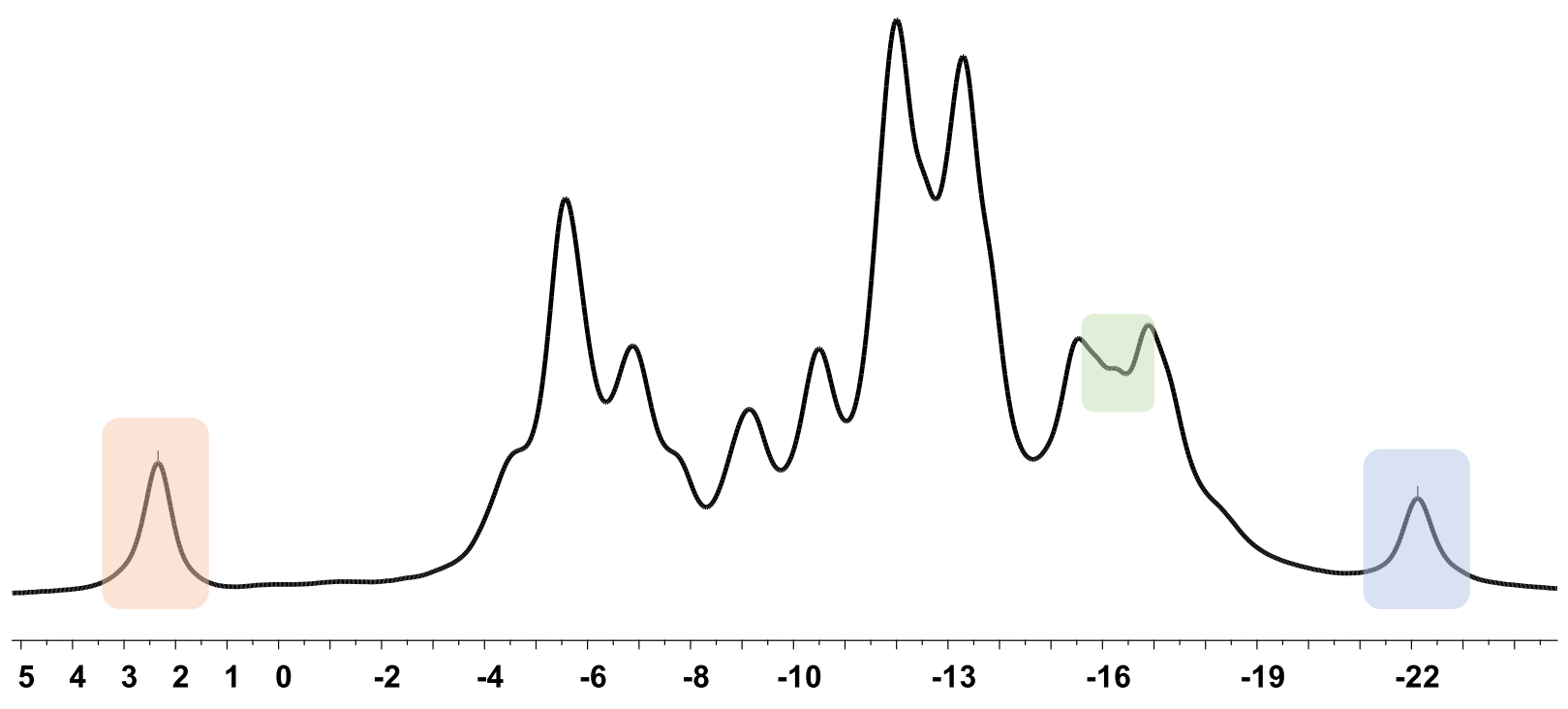




\section{c. Reaction of 3A with Phenylacetylene in Chloroform}

3A (57 mg, $0.15 \mathrm{mmol}, 1 \mathrm{eq})$ was added to an oven dried reaction tube equipped with a stir bar and PTFE cap before the reaction tube was evacuated and backfilled with $\mathrm{N}_{2}$ three times, followed by the addition of $\mathrm{CHCl}_{3}(0.75 \mathrm{~mL})$ via syringe. Phenylacetylene $(33 \mu \mathrm{L}, 0.3 \mathrm{mmol}, 2 \mathrm{eq})$ was then added to the suspension under a positive flow of $\mathrm{N}_{2}$, and the reaction tube was then sealed. The resulting mixture was then heated to reflux $\left(65^{\circ} \mathrm{C}\right)$ in an oil bath and left to stir for $8 \mathrm{~h}$. After stirring for $8 \mathrm{~h}$, the reaction was allowed to cool to room temperature and the chloroform was removed from the reaction tube under high vacuum and redissolved in THF. The resulting solution was then transferred to an NMR tube for in situ ${ }^{11} \mathrm{~B}$ NMR spectroscopy to determine conversion to the desired product. The in situ ${ }^{11} \mathrm{~B}$ NMR is included below. The ${ }^{11} \mathrm{~B}$ NMR spectrum reveals that the mixture is largely comprised of starting material and ditelluride (1B). Red highlight indicates ${ }^{11} \mathrm{~B}$ resonance associated with starting material. Blue highlight indicated ${ }^{11} \mathrm{~B}$ resonance associated with 1B. Green highlight indicates the expected chemical shift for the desired telluride product. The ${ }^{11} \mathrm{~B}$ resonance associated with the desired product appears to be slightly more pronounced than when the reaction was performed in $\mathrm{CH}_{2} \mathrm{Cl}_{2}$, suggesting slightly improved conversion. However, there still remains significant quantities of starting materials and $\mathbf{1 B}$.

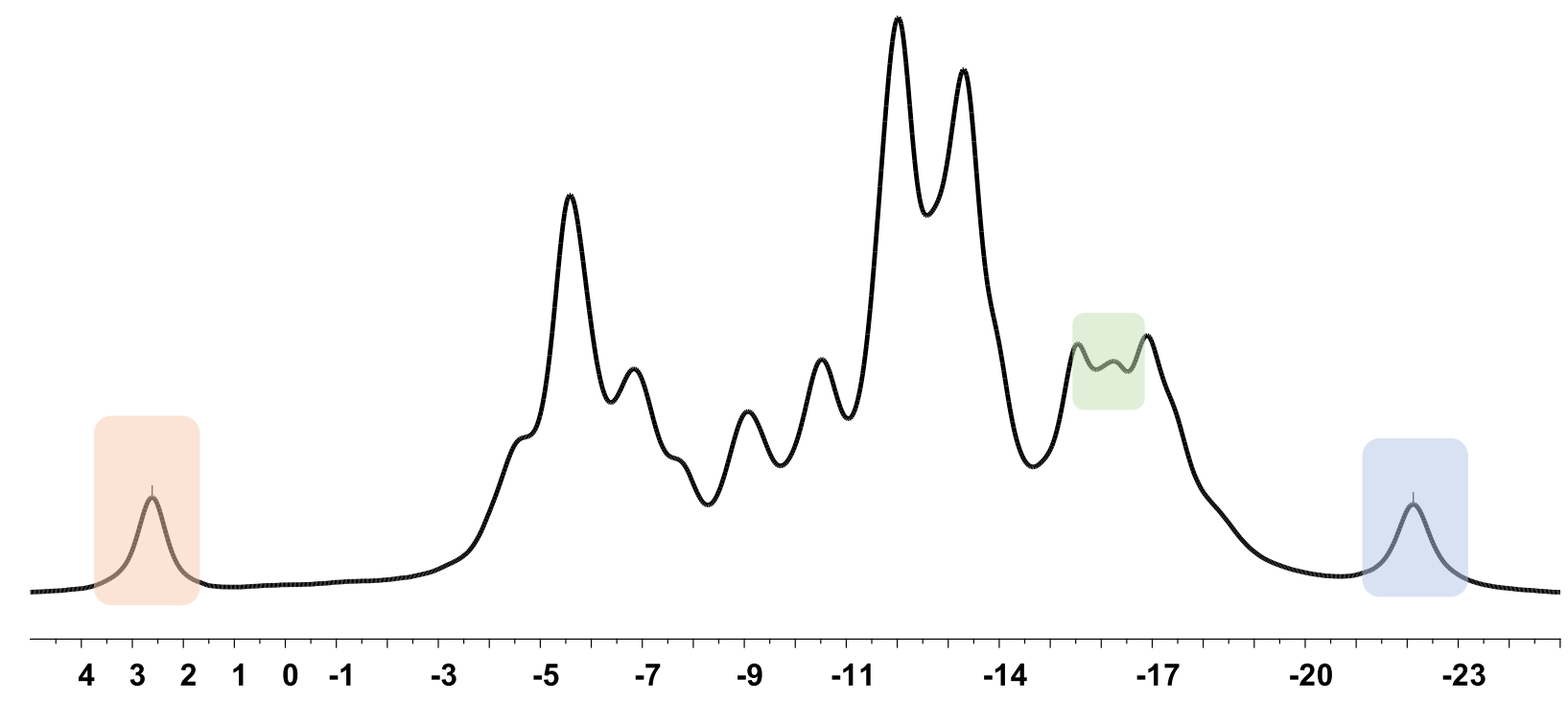

7. Reactions of Tellurenyl (IV) Chloride (4A)

a. Synthesis of $4 B$ and $4 B$ ' 


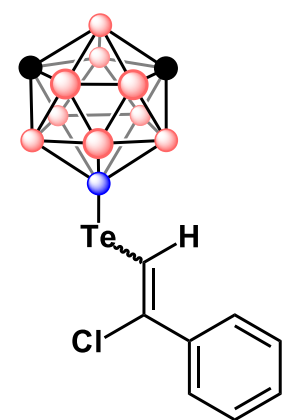

4B \& 4B'

4A (57 mg, $0.15 \mathrm{mmol}, 1 \mathrm{eq}$ ) was added to an oven dried reaction tube equipped with a stir bar and PTFE cap before the reaction tube was evacuated and backfilled with $\mathrm{N}_{2}$ three times, followed by the addition of $\mathrm{CHCl}_{3}(0.75 \mathrm{~mL})$ via syringe. Phenylacetylene ( $33 \mu \mathrm{L}, 0.3 \mathrm{mmol}, 2 \mathrm{eq})$ was then added to the suspension under a positive flow of $\mathrm{N}_{2}$, and the reaction tube was then sealed. The resulting mixture was then heated to reflux $\left(65^{\circ} \mathrm{C}\right)$ in an oil bath and left to stir for $8 \mathrm{~h}$. After stirring for $8 \mathrm{~h}$, the reaction was allowed to cool to room temperature and the reaction mixture was transferred to an NMR tube for in situ ${ }^{11} \mathrm{~B}$ and ${ }^{125} \mathrm{Te}$ NMR spectroscopy to confirm the formation of intermediate $\mathbf{4 B} *$. Once the formation of $\mathbf{4 B}$ * was confirmed, the reaction mixture was then transferred back to a reaction tube equipped with a stir bar and $1 \mathrm{~mL}$ of an aqueous solution of sodium thiosulfate $(0.2$ $\mathrm{g} / \mathrm{mL}$ ) was added. The resulting biphasic solution was stirred vigorously for 1 hour and monitored by TLC (10:90 $\mathrm{CH}_{2} \mathrm{Cl}_{2}$ :Hexanes). Once the reaction was determined complete by TLC, the organic layer of the biphasic mixture was collected and the remaining aqueous layer was extracted with $\mathrm{CH}_{2} \mathrm{Cl}_{2}(3 \times 3 \mathrm{~mL})$. The crude product was then dry loaded onto silica and volatiles were removed under reduced pressure, before subjecting the crude product to silica gel column chromatography using a hexanes to $20 \% \mathrm{CH}_{2} \mathrm{Cl}_{2}$ :Hexanes gradient. The product-containing fractions were collected and volatiles were removed under reduced pressure, affording the product as a yellow-brown oil in $70 \%$ isolated yield.

Yield: $43 \mathrm{mg}$ (70\%), yellow-brown oil

9-Te-Z/E-(2/2-chloro-2/2-phenylvinyltelluride)-1,7-dicarba-closo-dodecaborane (4B/4B')

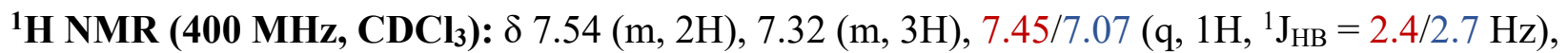
3.6-1.5 (m, 9H, B carborane-H), $3.13\left(\mathrm{~s}, 2 \mathrm{H}, \mathrm{C}_{\text {carborane }}-\mathrm{H}\right)$

${ }^{13} \mathbf{C}\left\{{ }^{1} \mathbf{H}\right\}$ NMR (100 MHz, $\left.\mathbf{C D C l}_{3}\right): \delta 139.24,138.24,128.89,128.45,128.33,128.23,128.06$, $126.14,102.30,97.10,57.40,57.27$

${ }^{11}$ B NMR (128 MHz): $\delta-5.71\left(\mathrm{~d}, 2 \mathrm{~B},{ }^{1} \mathrm{~J}_{\mathrm{BH}}=161 \mathrm{~Hz}\right),-8.93\left(\mathrm{~d}, 1 \mathrm{~B},{ }^{1} \mathrm{~J}_{\mathrm{BH}}=153 \mathrm{~Hz}\right),-12.42(\mathrm{~d}, 4 \mathrm{~B}$, $\left.{ }^{1} \mathrm{~J}_{\mathrm{BH}}=166 \mathrm{~Hz}\right),-16.25(\mathrm{~s}, 1 \mathrm{~B}),-16.28\left(\mathrm{~d}, 2 \mathrm{~B},{ }^{1} \mathrm{~J}_{\mathrm{BH}}=172 \mathrm{~Hz}\right)$

${ }^{125}$ Te NMR (158 MHz): $\delta-9.8\left(\mathrm{q},{ }^{1} \mathrm{~J}_{\mathrm{TeB}}=147 \mathrm{~Hz}\right),-14.8\left(\mathrm{q},{ }^{1} \mathbf{J}_{\mathrm{TeB}}=144 \mathrm{~Hz}\right)$

GC-MS $m / z: 409.10$ (calc. 409.10)

\section{9-TeCl 2 -(2-chloro-1-phenylvinyltelluride)-1,7-dicarba-closo-dodecaborane (4B*/4B'*)}

${ }^{11}$ B NMR (128 MHz): $\delta-6.32(\mathrm{~s}, 1 \mathrm{~B}),-6.61(\mathrm{~d}, 2 \mathrm{~B}),-10.20\left(\mathrm{~d}, 1 \mathrm{~B},{ }^{1} \mathrm{~J}_{\mathrm{BH}}=154 \mathrm{~Hz}\right),-13.07(\mathrm{~d}, 4 \mathrm{~B}$, $\left.{ }^{1} \mathrm{~J}_{\mathrm{BH}}=163 \mathrm{~Hz}\right),-16.82\left(\mathrm{~d}, 2 \mathrm{~B},{ }^{1} \mathrm{~J}_{\mathrm{BH}}=180 \mathrm{~Hz}\right)$

${ }^{125}$ Te NMR (158 MHz): $\delta 566.3(\mathrm{~m}), 546.9(\mathrm{~m})$

\section{b. Radical Mechanism Inhibition Experiments}

4A (38 mg, $0.10 \mathrm{mmol}, 1 \mathrm{eq})$ and dihydroanthracene (18 mg, $0.10 \mathrm{mmol}, 1 \mathrm{eq}$ ), a known radical inhibitor, were added to an oven dried reaction tube equipped with a stir bar and PTFE cap before the reaction tube was evacuated and backfilled with $\mathrm{N}_{2}$ three times, followed by the addition of 
$\mathrm{CHCl}_{3}(0.75 \mathrm{~mL})$ via syringe. Phenylacetylene $(22 \mu \mathrm{L}, 0.2 \mathrm{mmol}, 2 \mathrm{eq})$ was then added to the suspension under a positive flow of $\mathrm{N}_{2}$, and the reaction tube was then sealed. The resulting mixture was then heated to reflux $\left(65^{\circ} \mathrm{C}\right)$ in an oil bath and left to stir for $8 \mathrm{~h}$. After stirring for 8 $\mathrm{h}$, the reaction was allowed to cool to room temperature and the now clear reaction mixture was transferred to an NMR tube for in situ ${ }^{125}$ Te NMR spectroscopy to confirm the formation of desired intermediate and relative intensities for the resonances associated with $\mathbf{4} \mathrm{B}^{*}$ and $\mathbf{4 B} \mathbf{B}^{\boldsymbol{*}}$. The in situ ${ }^{125}$ Te NMR provided below shows no significant change in the relative intensity (approx. 1:2) of the two resonances associated with both isomers. The result of this experiment rules out the possibility of a radical-based mechanism in the formation of the minor isomer.

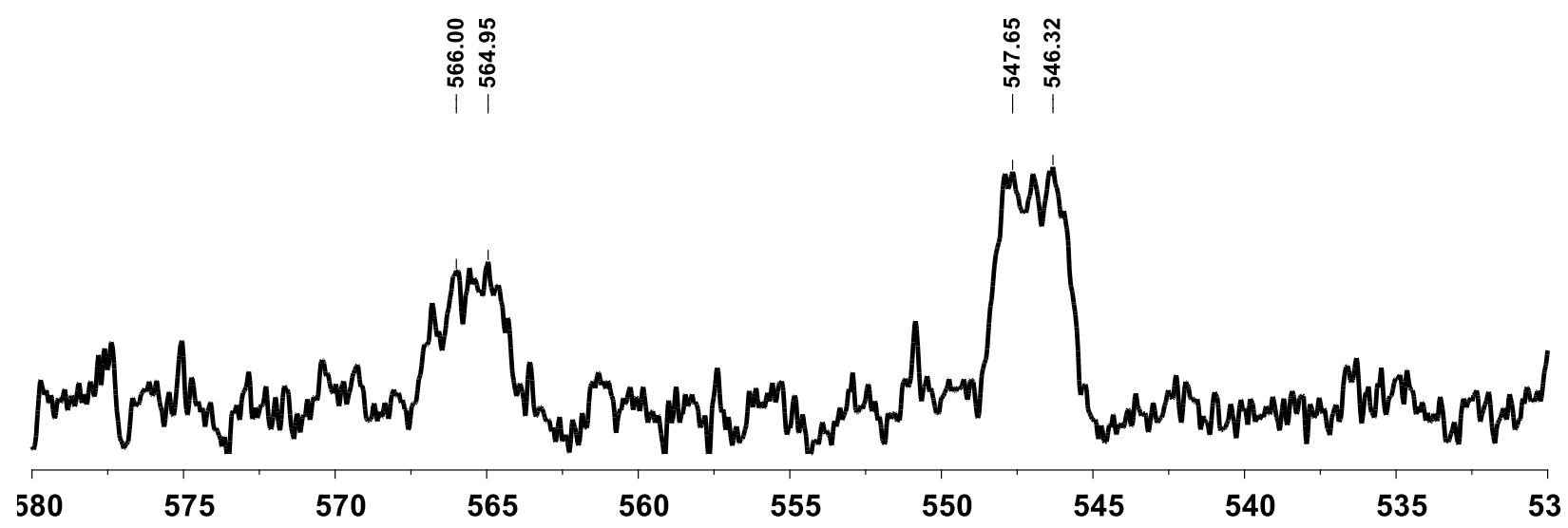

\section{c. Solvent Polarity Experiments}

4A (38 mg, $0.10 \mathrm{mmol}, 1 \mathrm{eq}$ ) was added to an oven dried reaction tube equipped with a stir bar and PTFE cap before the reaction tube was evacuated and backfilled with $\mathrm{N}_{2}$ three times, followed by the addition of toluene $(0.75 \mathrm{~mL})$ via syringe. Phenylacetylene $(22 \mu \mathrm{L}, 0.2 \mathrm{mmol}, 2 \mathrm{eq})$ was then added to the suspension under a positive flow of $\mathrm{N}_{2}$, and the reaction tube was then sealed. The resulting mixture was then heated to $65^{\circ} \mathrm{C}$ in an oil bath and left to stir for $8 \mathrm{~h}$. After stirring for $8 \mathrm{~h}$, the reaction was allowed to cool to room temperature and the now clear reaction mixture was transferred to an NMR tube for in situ ${ }^{125}$ Te NMR spectroscopy to confirm the formation of desired intermediate and relative intensities for the resonances associated with $4 \mathrm{~B}^{*}$ and $\mathbf{4 B} \mathbf{B}^{*}$. The in situ ${ }^{125} \mathrm{Te}$ NMR provided below shows only the formation of the $Z$ isomer, with no observable resonance for the $E$ isomer. The influence of solvent polarity on isomer distribution agrees with the mechanistic behavior of other organic-based tellurenyl (IV) chlorides. 


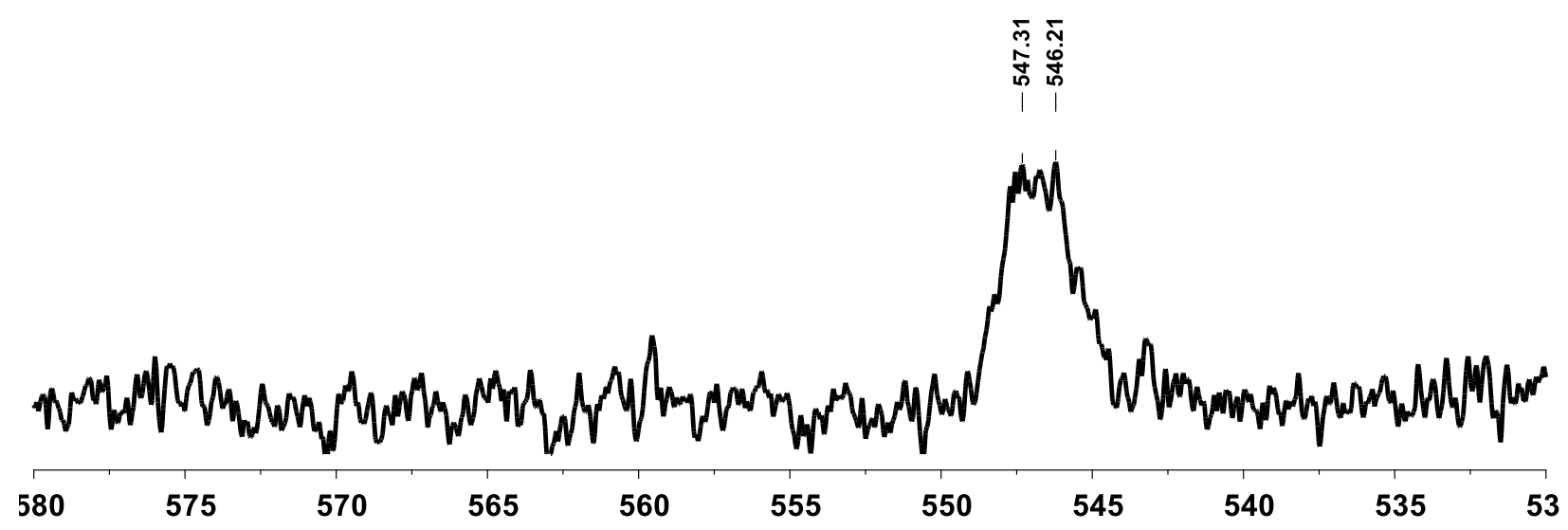

\section{Synthesis and Nucleophilic Reactions of Selenol (5A-B)}

a. Synthesis of $\mathbf{5 A}$

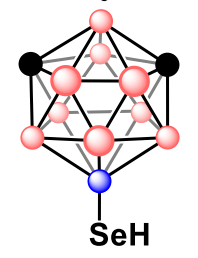

$5 \mathrm{~A}$

Synthetic procedures adapted from references 4 and $6.1 \mathrm{~A}(2.23 \mathrm{~g}, 5 \mathrm{mmol}, 1 \mathrm{eq})$ was added to a $300 \mathrm{~mL}$ round bottomed flask equipped with a stir bar and rubber septum with a bleed needle. A minimal amount of absolute EtOH (30-50 mL) was added to the flask, resulting in a red-orange solution with some solids still suspended (sonication may be required). While stirring the solution of $\mathbf{1 A}$, an excess of $\mathrm{NaBH}_{4}$ addition, some heat and gas was generated, with the consumption of $\mathbf{1 A}$ indicated by the reaction mixture turning cloudy and colorless. The reduction was stirred for an additional 15 minutes before the dropwise addition of aqueous $\mathrm{HCl}(\sim 2 \mathrm{M}, 10-20 \mathrm{~mL})$ to quench any residual $\mathrm{NaBH}_{4}$ and protonate the selenolate intermediate. Once no more gas was evolved upon the addition of $\mathrm{HCl}$, distilled $\mathrm{H}_{2} \mathrm{O}(200 \mathrm{~mL})$ was added resulting in a foamy, pale yellow suspension. The product was then extracted from the aqueous solution with $\mathrm{CH}_{2} \mathrm{Cl}_{2}(4 \times 30 \mathrm{~mL})$ and the collected organic layers were dried over $\mathrm{Na}_{2} \mathrm{SO}_{4}$. The dried organic layers were decanted away from the $\mathrm{Na}_{2} \mathrm{SO}_{4}$ and all volatiles were removed under reduced pressure, leaving the crude product as a pale yellow solid. The crude product was further purified via vacuum sublimation at $90{ }^{\circ} \mathrm{C}$, affording the product as a white, crystalline solid in $58 \%$ yield.

Note: for the purpose of synthesizing $\mathbf{5 A}, \mathbf{1 A}$ does not need to be purified via silica gel column chromatography first and can be used, as is.

Yield: $1.3 \mathrm{~g}(58 \%)$, white solid

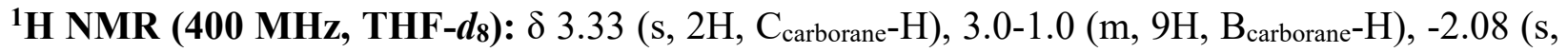
$1 \mathrm{H})$

${ }^{13} \mathrm{C}\left\{{ }^{1} \mathrm{H}\right\}$ NMR (100 MHz, THF-d8): $\delta 56.28$

${ }^{11}$ B NMR (128 MHz): $\delta-5.97\left(\mathrm{~d}, 2 \mathrm{~B},{ }^{1} \mathrm{~J}_{\mathrm{BH}}=165 \mathrm{~Hz}\right),-7.84(\mathrm{~s}, 1 \mathrm{~B}),-8.99\left(\mathrm{~d}, 1 \mathrm{~B},{ }^{1} \mathrm{~J}_{\mathrm{BH}}=183 \mathrm{~Hz}\right)$, $-12.33\left(\mathrm{~d}, 2 \mathrm{~B},{ }^{1} \mathrm{~J}_{\mathrm{BH}}=161 \mathrm{~Hz}\right),-13.58\left(\mathrm{~d}, 2 \mathrm{~B},{ }^{1} \mathrm{~J}_{\mathrm{BH}}=165 \mathrm{~Hz}\right),-17.14\left(\mathrm{~d}, 1 \mathrm{~B},{ }^{1} \mathrm{~J}_{\mathrm{BH}}=180 \mathrm{~Hz}\right),-19.79$ $\left(\mathrm{d}, 1 \mathrm{~B},{ }^{1} \mathrm{~J}_{\mathrm{BH}}=183 \mathrm{~Hz}\right)$

${ }^{77}$ Se NMR (95 MHz): $\delta-281.3(\mathrm{~m}, \mathrm{~b})$ 
GC-MS $m / z: 223.20$ (calc. 223.11)

\section{b. Synthesis of $\mathbf{5 B}$}

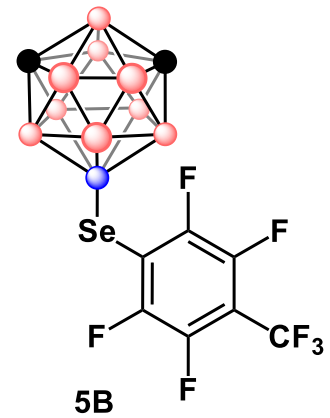

5A (35 mg, $0.15 \mathrm{mmol}, 1 \mathrm{eq})$ and anhydrous $\mathrm{Cs}_{2} \mathrm{CO}_{3}(54 \mathrm{mg}, 0.17 \mathrm{mmol}, 1.1$ eq) were added to an oven dried reaction tube equipped with a stir bar and PTFE cap before the reaction tube was evacuated and backfilled with $\mathrm{N}_{2}$ three times. Subsequently, anhydrous DMF $(1 \mathrm{~mL})$ was added to the reaction tube and the resulting suspension was stirred for 5 minutes before the addition of perfluorotoluene $(23.4 \mu \mathrm{L}, 0.15 \mathrm{mmol}, 1 \mathrm{eq})$. The reaction was then left to stir for $16 \mathrm{~h}$ at room temperature. After $16 \mathrm{~h}$, distilled $\mathrm{H}_{2} \mathrm{O}(10 \mathrm{~mL})$ was added to the reaction mixture, and organics were extracted from the emulsion with Hexanes $(3 \times 3 \mathrm{~mL})$. The collected organic layers were then passed through a $2 \mathrm{~cm}$ silica plug and eluted with hexanes. Volatiles were removed from the filtrate under reduced pressure, affording the product as a white solid in $61 \%$ isolated yield.

Yield: $40 \mathrm{mg}(61 \%)$, white solid

${ }^{1}$ H NMR (400 MHz, CDCl 3 ): $\delta 3.5-1.5$ (m, 9H, B carborane-H) 3.03 (s, 2H, C carborane-H)

${ }^{13} \mathrm{C}\left\{{ }^{1} \mathrm{H}\right\}$ NMR (100 MHz, $\left.\mathrm{CDCl}_{3}\right): \delta 55.64$

${ }^{19}$ F NMR (396 MHz): $\delta-56.31\left(\mathrm{t}, 3 \mathrm{~F},{ }^{1} \mathrm{~J}_{\mathrm{FF}}=21.8 \mathrm{~Hz}\right),-123.10\left(\mathrm{td}, 2 \mathrm{~F},{ }^{1} \mathrm{~J}_{\mathrm{FF}}=16.4 \mathrm{~Hz}, 6.6 \mathrm{~Hz}\right)$, $140.13\left(\mathrm{ddd}, 2 \mathrm{~F},{ }^{1} \mathrm{~J}_{\mathrm{FF}}=22.0 \mathrm{~Hz}, 15.2 \mathrm{~Hz}, 9.8 \mathrm{~Hz}\right)$

${ }^{11}$ B NMR (128 MHz): $\delta-5.64(\mathrm{~s}, 1 \mathrm{~B}),-6.13\left(\mathrm{~d}, 2 \mathrm{~B},{ }^{1} \mathrm{~J}_{\mathrm{BH}}=161 \mathrm{~Hz}\right),-9.47\left(\mathrm{~d}, 1 \mathrm{~B},{ }^{1} \mathrm{~J}_{\mathrm{BH}}=152 \mathrm{~Hz}\right)$, $-13.37\left(\mathrm{~d}, 2 \mathrm{~B},{ }^{1} \mathrm{~J}_{\mathrm{BH}}=168 \mathrm{~Hz}\right),-17.17\left(\mathrm{~d}, 1 \mathrm{~B},{ }^{1} \mathrm{~J}_{\mathrm{BH}}=188 \mathrm{~Hz}\right),-19.19\left(\mathrm{~d}, 1 \mathrm{~B},{ }^{1} \mathrm{~J}_{\mathrm{BH}}=190 \mathrm{~Hz}\right)$

${ }^{77}$ Se NMR (95 MHz): $\delta-48.2(\mathrm{~m})$

GC-MS $m / z: 440.20$ (calc. 440.09)

\section{Synthesis and Nucleophilic Reactions of Tellurol (6A-C)}

a. Synthesis of $6 \mathrm{~A}$

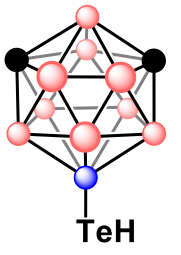

$6 \mathrm{~A}$

Synthetic procedures adapted from reference 4 and 6 . In a darkened fumehood, 1B (270 mg, $0.5 \mathrm{mmol}, 1 \mathrm{eq}$ ) was added to a $25 \mathrm{~mL}$ Schlenk flask equipped with a stir bar and rubber septum and the flask was subsequently evacuated and back filled with $\mathrm{N}_{2}$ three times. A minimal amount of absolute $\mathrm{EtOH}(10 \mathrm{~mL})$ was the added to the flask via syringe, resulting in a deep red solution with some solids still suspended. While stirring the solution of $\mathbf{1 B}$, an excess of $\mathrm{NaBH}_{4}(\sim 150 \mathrm{mg})$ was carefully added over the course of several minutes under positive pressure of $\mathrm{N}_{2}$. During the course of addition, some heat and gas was generated, with the consumption of $\mathbf{1 B}$ indicated by the reaction mixture turning colorless. The reduction was stirred for an additional 15 minutes before the dropwise addition of aqueous $\mathrm{HCl}(\sim 2 \mathrm{M}, 10 \mathrm{~mL})$ to quench any residual $\mathrm{NaBH}_{4}$ and protonate the tellurolate intermediate. Once no more gas was evolved upon the addition of $\mathrm{HCl}, \mathrm{CH}_{2} \mathrm{Cl}_{2}(3 \mathrm{~mL})$ was added to the Schlenk flask with gentle stirring, resulting in an orange organic layer at the bottom of the flask. The organic layer was then carefully collected from the flask using a glass pipette and deposited in a $50 \mathrm{~mL}$ round bottomed flask over a flow of $\mathrm{N}_{2}$. The remaining aqueous layer was 
extracted with additional $\mathrm{CH}_{2} \mathrm{Cl}_{2}(2 \times 3 \mathrm{~mL})$ and the collected organic layers were dried on a highvacuum line in the dark, leaving behind an orange powder. The orange powder was then collected in a microsublimator and gradually heated to $50{ }^{\circ} \mathrm{C}$ in an oil bath while under vacuum. The tellurol was then collected from the cold finger as a white, odorless, crystals in 67\% isolated yield and quickly transferred into a glovebox freezer set to $-30{ }^{\circ} \mathrm{C}$.

Note: for the purpose of synthesizing 6A, 1B does need to be purified via silica gel column chromatography first.

Yield: $181 \mathrm{mg}(67 \%)$, white solid

${ }^{1}$ H NMR (400 MHz, THF-d8): $\delta 3.70\left(\mathrm{~s}, 2 \mathrm{H}, \mathrm{C}_{\text {carborane }}-\mathrm{H}\right), 3.5-1.5$ (m, 9H, B carborane-H) $_{\text {) }}$-7.15 (q, $\left.1 \mathrm{H},{ }^{1} \mathrm{~J}_{\mathrm{HB}}=5.2 \mathrm{~Hz}\right)$

${ }^{13} \mathrm{C}\left\{{ }^{1} \mathrm{H}\right\}$ NMR (100 MHz, THF-d8): $\delta 58.31$

${ }^{11}$ B NMR (128 MHz): $\delta-5.07\left(\mathrm{~d}, 2 \mathrm{~B},{ }^{1} \mathrm{~J}_{\mathrm{BH}}=168 \mathrm{~Hz}\right),-8.00\left(\mathrm{~d}, 1 \mathrm{~B},{ }^{1} \mathrm{~J}_{\mathrm{BH}}=152 \mathrm{~Hz}\right),-11.28(\mathrm{~d}, 2 \mathrm{~B}$, $\left.{ }^{1} \mathrm{~J}_{\mathrm{BH}}=152 \mathrm{~Hz}\right),-12.37\left(\mathrm{~d}, 2 \mathrm{~B},{ }^{1} \mathrm{~J}_{\mathrm{BH}}=155 \mathrm{~Hz}\right),-15.98\left(\mathrm{~d}, 1 \mathrm{~B},{ }^{1} \mathrm{~J}_{\mathrm{BH}}=172 \mathrm{~Hz}\right),-17.11\left(\mathrm{~d}, 1 \mathrm{~B},{ }^{1} \mathrm{~J}_{\mathrm{BH}}\right.$ $=152 \mathrm{~Hz}),-20.48(\mathrm{~s}, 1 \mathrm{~B})$

${ }^{125}$ Te NMR (158 MHz): $\delta-596.5\left(\mathrm{q},{ }^{1} \mathrm{~J}_{\mathrm{TeB}}=126 \mathrm{~Hz}\right)$

GC-MS $m / z: 270.00$ (calc. 270.10)

\section{b. Synthesis of $6 \mathrm{~B}$}

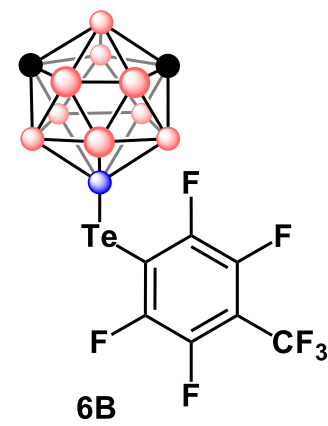

In a dark, $\mathrm{N}_{2}$-filled glovebox, 6A (41 $\left.\mathrm{mg}, 0.15 \mathrm{mmol}, 1 \mathrm{eq}\right)$ and anhydrous $\mathrm{Cs}_{2} \mathrm{CO}_{3}$ (54 mg, $0.17 \mathrm{mmol}, 1.1 \mathrm{eq}$ ) were added to $4 \mathrm{~mL}$ dram vial equipped with a stir bar and PTFE cap. Subsequently, a solution of degassed, anhydrous DMF ( $1 \mathrm{~mL})$ and perfluorotoluene $(23.4 \mu \mathrm{L}, 0.15 \mathrm{mmol}, 1 \mathrm{eq})$ was quickly added to the vial. The resulting dark red solution was then left to stir for $16 \mathrm{~h}$ at room temperature in the dark. After $16 \mathrm{~h}$, the dram vial was removed from the glovebox and the reaction solution was transferred to a separatory funnel containing distilled $\mathrm{H}_{2} \mathrm{O}(10 \mathrm{~mL})$. Organics were then extracted from the emulsion with Hexanes $(3 \times 3 \mathrm{~mL})$. The collected organic layers were then passed through a $2 \mathrm{~cm}$ silica plug and eluted with hexanes. Volatiles were removed from the filtrate under reduced pressure, affording the product as a white solid in $13 \%$ isolated yield.

Yield: $10 \mathrm{mg}(13 \%)$, white solid

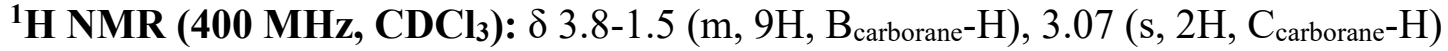

${ }^{13} \mathrm{C}\left\{{ }^{1} \mathrm{H}\right\}$ NMR (100 MHz, $\left.\mathrm{CDCl}_{3}\right): \delta 57.31$

${ }^{19}$ F NMR (396 MHz): $\delta-56.37\left(\mathrm{t}, 3 \mathrm{~F},{ }^{1} \mathrm{~J}_{\mathrm{FF}}=21.8 \mathrm{~Hz}\right),-111.01\left(\mathrm{td}, 2 \mathrm{~F},{ }^{1} \mathrm{~J}_{\mathrm{FF}}=16.8 \mathrm{~Hz}, 5.9 \mathrm{~Hz}\right)$, $139.61(\mathrm{~m}, 2 \mathrm{~F})$

${ }^{11}$ B NMR (128 MHz): $\delta-5.56\left(\mathrm{~d}, 2 \mathrm{~B},{ }^{1} \mathrm{~J}_{\mathrm{BH}}=168 \mathrm{~Hz}\right),-8.75\left(\mathrm{~d}, 1 \mathrm{~B},{ }^{1} \mathrm{~J}_{\mathrm{BH}}=152 \mathrm{~Hz}\right),-12.48(\mathrm{~d}, 4 \mathrm{~B}$, $\left.{ }^{1} \mathrm{~J}_{\mathrm{BH}}=152 \mathrm{~Hz}\right),-16.29(\mathrm{~m}, 3 \mathrm{~B})$

${ }^{125}$ Te NMR (158 MHz): $\delta-84.2$ (m) 
GC-MS $m / z: 489.10$ (calc. 489.08)

\section{c. Synthesis of $6 \mathrm{C}$}

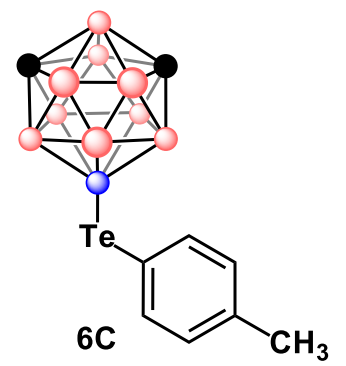

In a dark, $\mathrm{N}_{2}$-filled glovebox, 6A (41 mg, $\left.0.15 \mathrm{mmol}, 1 \mathrm{eq}\right)$ and [4-tolylPdRuPhos][OTf] (125 mg, $0.15 \mathrm{mmol}, 1 \mathrm{eq})$ were added to $4 \mathrm{~mL}$ dram vial equipped with a stir bar and PTFE cap. Subsequently, anhydrous $\mathrm{CH}_{2} \mathrm{Cl}_{2}$ (2 $\mathrm{mL}$ ) was added to the vial and the resulting mixture was vigorously stirred for 30 minutes at room temperature. After 30 minutes, the vial was removed from the glovebox and all volatiles were removed under reduced pressure. gel, using $20 \% \mathrm{CH}_{2} \mathrm{Cl}_{2}$ :Hexanes as eluent. The product containing fractions were collected and volatiles were removed under reduced pressure, affording the desired product in $56 \%$ isolated yield.

Yield: $30 \mathrm{mg}$ (56\%), white solid

${ }^{1} \mathbf{H}$ NMR (400 MHz, $\left.\mathbf{C D C l}_{3}\right): \delta 7.69\left(\mathrm{~d}, 2 \mathrm{H},{ }^{1} \mathrm{~J}_{\mathrm{HH}}=7.9 \mathrm{~Hz}\right), 6.96\left(\mathrm{~d}, 2 \mathrm{H},{ }^{1} \mathrm{~J}_{\mathrm{HH}}=7.6 \mathrm{~Hz}\right), 3.6-1.6$ (m, 9H, B carborane $\mathrm{H}), 3.00\left(\mathrm{~s}, 2 \mathrm{H}, \mathrm{C}_{\text {carborane }}-\mathrm{H}\right)$

${ }^{13} \mathbf{C}\left\{{ }^{1} \mathbf{H}\right\}$ NMR (100 MHz, $\left.\mathbf{C D C l}_{3}\right): \delta 140.82,129.78,56.95,21.27$

${ }^{11}$ B NMR (128 MHz): $\delta-5.77\left(\mathrm{~d}, 2 \mathrm{~B},{ }^{1} \mathrm{~J}_{\mathrm{BH}}=161 \mathrm{~Hz}\right),-8.79\left(\mathrm{~d}, 1 \mathrm{~B},{ }^{1} \mathrm{~J}_{\mathrm{BH}}=155 \mathrm{~Hz}\right),-12.68(\mathrm{~d}, 4 \mathrm{~B}$, $\left.{ }^{1} \mathrm{~J}_{\mathrm{BH}}=168 \mathrm{~Hz}\right),-16.48(\mathrm{~m}, 3 \mathrm{~B})$

${ }^{125}$ Te NMR (158 MHz): $\delta 46.5\left(\mathrm{q},{ }^{1} \mathrm{~J}_{\mathrm{TeB}}=161 \mathrm{~Hz}\right)$

GC-MS $m / z: 363.20$ (calc. 363.15 )

\section{d. In situ ${ }^{11}$ B NMR Spectroscopy of Crude 6B}

Representative in situ ${ }^{11} \mathrm{~B}$ NMR spectrum of crude 6B. The majority of the reaction mixture $(>85 \%)$ consists of $\mathbf{1 B}$ as determined by the ${ }^{11} \mathrm{~B}$ resonance at $-22 \mathrm{ppm}$.

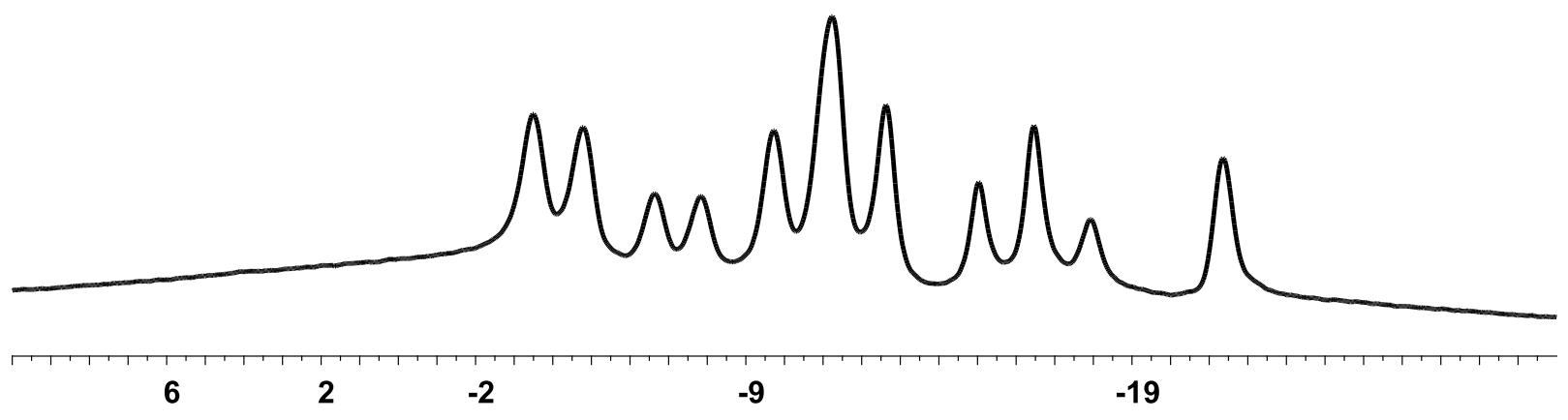




\section{X-ray Crystallography Details}

Table S1. Crystal data and structure refinement for 1A

CCDC number

Empirical formula

Formula weight

Temperature

Wavelength

Crystal system

Space group

Unit cell dimensions

Volume

Z

Density (calculated)

Absorption coefficient

$F(000)$

Crystal size

Theta range for data collection

Index ranges

Reflections collected

Independent reflections

Completeness to theta $=25.242^{\circ}$

Absorption correction

Max. and min. transmission

Refinement method

Data / restraints / parameters

Goodness-of-fit on $F^{2}$

Final R indices $[I>2 \sigma(I)]$

$R$ indices (all data)
2105009

$\mathrm{C}_{4} \mathrm{H}_{22} \mathrm{~B}_{20} \mathrm{Se}_{2}$

444.33

$100.0 \mathrm{~K}$

$0.71073 \AA$

Orthorhombic

Pbcn

$\begin{array}{ll}\mathrm{a}=17.3364(5) \AA & \alpha=90^{\circ} . \\ \mathrm{b}=17.1498(7) \AA & \beta=90^{\circ} . \\ \mathrm{c}=13.1219(5) \AA & \gamma=90^{\circ} .\end{array}$

3901.3(2) $\AA^{3}$

8

$1.513 \mathrm{Mg} / \mathrm{m}^{3}$

$3.775 \mathrm{~mm}^{-1}$

1712

$0.33 \times 0.31 \times 0.28 \mathrm{~mm}^{3}$

2.280 to $28.315^{\circ}$.

$-23<=h<=23,-22<=k<=22,-17<=l<=17$

60353

$4828[R($ int $)=0.0503]$

$99.6 \%$

Semi-empirical from equivalents

0.688 and 0.488

Full-matrix least-squares on $F^{2}$

4828 / 0 / 235

1.140

$R 1=0.0446, \mathrm{w} R 2=0.0897$

$R 1=0.0536, \mathrm{w} R 2=0.0940$ 
Extinction coefficient n/a

Largest diff. peak and hole 1.037 and -1.930 e. $\AA^{-3}$

Table S2. Crystal data and structure refinement for 1B

CCDC number

Empirical formula

Formula weight

Temperature

Wavelength

Crystal system

Space group

Unit cell dimensions

Volume

Z

Density (calculated)

Absorption coefficient

$F(000)$

Crystal size

Theta range for data collection

Index ranges

Reflections collected

Independent reflections

Completeness to theta $=25.242^{\circ}$

Absorption correction

Max. and min. transmission

Refinement method

Data / restraints / parameters

Goodness-of-fit on $F^{2}$
2105007

$\mathrm{C}_{4} \mathrm{H}_{22} \mathrm{~B}_{20} \mathrm{Te}_{2}$

541.61

$100.0 \mathrm{~K}$

$0.71073 \AA$

Orthorhombic

Pbcn

$$
\begin{array}{ll}
\mathrm{a}=17.8707(6) \AA & \alpha=90^{\circ} . \\
\mathrm{b}=17.8162(7) \AA & \beta=90^{\circ} . \\
\mathrm{c}=12.9892(4) \AA & \gamma=90^{\circ} .
\end{array}
$$$$
\text { 4125.6(2) } \AA^{3}
$$

8

$1.740 \mathrm{Mg} / \mathrm{m}^{3}$

$2.807 \mathrm{~mm}^{-1}$

2000

$0.33 \times 0.31 \times 0.29 \mathrm{~mm}^{3}$

1.614 to $25.000^{\circ}$.

$-21<=h<=21,-21<=k<=21,-15<=l<=15$

25618

$3644[R($ int $)=0.0520, R($ sigma $)=0.0309]$

$99.9 \%$

Semi-empirical from equivalents

0.7454 and 0.6284

Full-matrix least-squares on $F^{2}$

3644 / 391 / 235

1.464 
Final R indices $[I>2 \sigma(I)]$

$$
\begin{aligned}
& R 1=0.0562, \mathrm{w} R 2=0.1461 \\
& R 1=0.0577, \mathrm{w} R 2=0.1472 \\
& \mathrm{n} / \mathrm{a}
\end{aligned}
$$

$R$ indices (all data)

Extinction coefficient

Largest diff. peak and hole 1.166 and -1.869 e. $\AA^{-3}$

Table S3. Crystal data and structure refinement for 2C

CCDC number

2105010

Empirical formula

$\mathrm{C}_{9} \mathrm{H}_{21} \mathrm{~B}_{10} \mathrm{ClSe}$

Formula weight

351.77

Temperature

$100.0 \mathrm{~K}$

Wavelength

$0.71073 \AA$

Crystal system

Orthorhombic

Space group

$P 2{ }_{1} 2_{12}{ }_{1}$

Unit cell dimensions

$\mathrm{a}=9.2033(4) \AA$

$\mathrm{b}=10.1545(5) \AA$

$\mathrm{c}=17.3382(8) \AA$

Volume

$1620.34(13) \AA^{3}$

Z

4

Density (calculated)

$1.442 \mathrm{Mg} / \mathrm{m}^{3}$

Absorption coefficient

$2.461 \mathrm{~mm}^{-1}$

$F(000)$

704

Index ranges

$-12<=h<=12,-13<=k<=13,-22<=l<=22$

Max. and min. transmission

0.625 and 0.738

Goodness-of-fit on $F^{2}$

1.74

$R$ indices (all data)

$R 1=0.0219, \mathrm{w} R 2=0.0522$

Extinction coefficient

$\mathrm{n} / \mathrm{a}$

Table S4. Crystal data and structure refinement for 2D

CCDC number

2105008

Empirical formula

$\mathrm{C}_{10} \mathrm{H}_{17} \mathrm{~B}_{10} \mathrm{ClSe}$ 
Formula weight

Temperature

Wavelength

Crystal system

Space group

Unit cell dimensions

Volume

Z

Density (calculated)

Absorption coefficient

$F(000)$

Crystal size

Theta range for data collection

Index ranges

Reflections collected

Independent reflections

Completeness to theta $=25.242^{\circ}$

Absorption correction

Max. and min. transmission

Refinement method

Data / restraints / parameters

Goodness-of-fit on $F^{2}$

Final R indices $[I>2 \sigma(I)]$

$R$ indices (all data)

Twinning
359.74

$100.0 \mathrm{~K}$

$0.71073 \AA$

Monoclinic

$P 21 / n$

$\mathrm{a}=7.8512(6) \AA$

$\alpha=90^{\circ}$.

$\mathrm{b}=10.2780(9) \AA$

$\mathrm{c}=20.4037(15) \AA$

$1616.6(2) \AA^{3}$

$\beta=100.930(3)^{\circ}$.

$\gamma=90^{\circ}$.

4

$1.478 \mathrm{Mg} / \mathrm{m}^{3}$

$2.469 \mathrm{~mm}^{-1}$

712

$0.33 \times 0.29 \times 0.11 \mathrm{~mm}^{3}$

1.981 to $26.411^{\circ}$.

$-9<=h<=9,-12<=k<=12,-25<=l<=25$

24508

$3387[R($ int $)=0.0683]$

$99.2 \%$

Semi-empirical from equivalents

0.672 and 0.499

Full-matrix least-squares on $F^{2}$

3387 / 0 / 200

1.123

$R 1=0.0572, \mathrm{w} R 2=0.1832$

$R 1=0.0588, \mathrm{w} R 2=0.1875$

$180 \mathrm{deg}$ rotational twin

Largest diff. peak and hole 0.618 and -1.493 e. $\AA^{-3}$ 


\section{References:}

1. Lenher, V.; Kao, C. H. The Preparation of Selenium Monochloride and Monobromide. $J$. Am. Chem. Soc. 1925 47, 3, 772-774.

2. Petragnani, N.; Mendes, S. R.; Silveria, C. C. Tellurium tetrachloride: an improved method of preparation. Tet. Lett. 2008 49, 15, 2371-2372.

3. Vinogradova, E. V.; Zhang, C.; Spokoyny, A. M.; Pentelute, B. L.; Buchwald, S. L. Organometallic palladium reagents for cysteine bioconjugation. Nature 2015, 526, 687691.

4. Zakharkin, L. I.; Pisareva, I. V.; Antonovich, V. A. Synthesis of Di(o- and $m$-Carboran9-yl) Diselenides by Electrophilic-Substitution Reactions of $o$ - and $m$-Carboranes with Selenium Chlorides Under the Action of $\mathrm{AlCl}_{3}$, and Reactions of These Products. Zhurnal Obshchei Khimii 1986, 56, 12, 2721-2728.

5. Zakharkin, L. I.; Pisareva, I. V. Synthesis and Some Conversions of Derivatives of $o$ - and $m$-Carborane Containing a B-Te $\sigma$ Bond. Izvestiya Akademii Nauk SSSR 1987, 4, 877880.

6. Spokoyny, A. M.; Machan, C. W.; Clingerman, D. J.; Rosen, M. S.; Wiester, M. J.; Kenedy, R. D.; Stern, C. L.; Sarjeant, A. A.; Mirkin, C. A. A coordination chemistry dichotomy for icosahedral carborane-based ligands. Nat. Chem. 2011, 3, 590-596. 


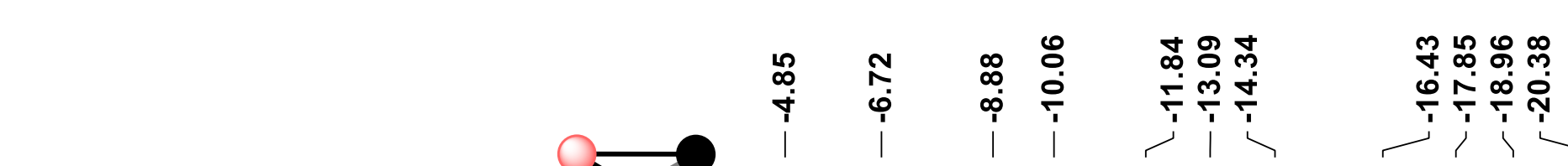

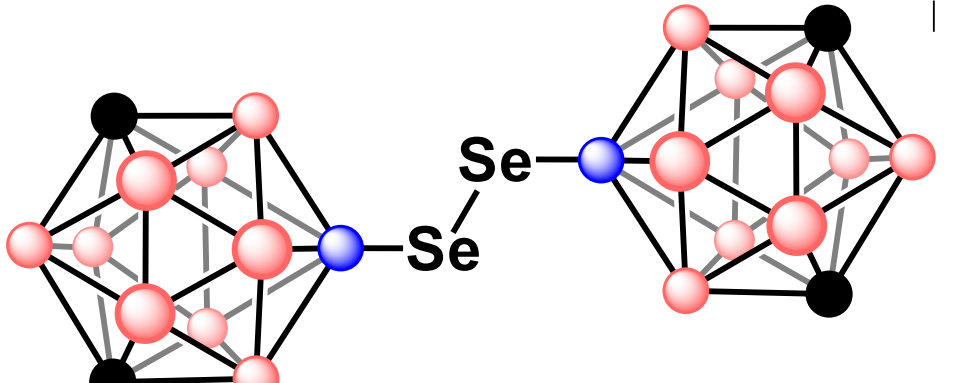

$1 \mathrm{~A}$

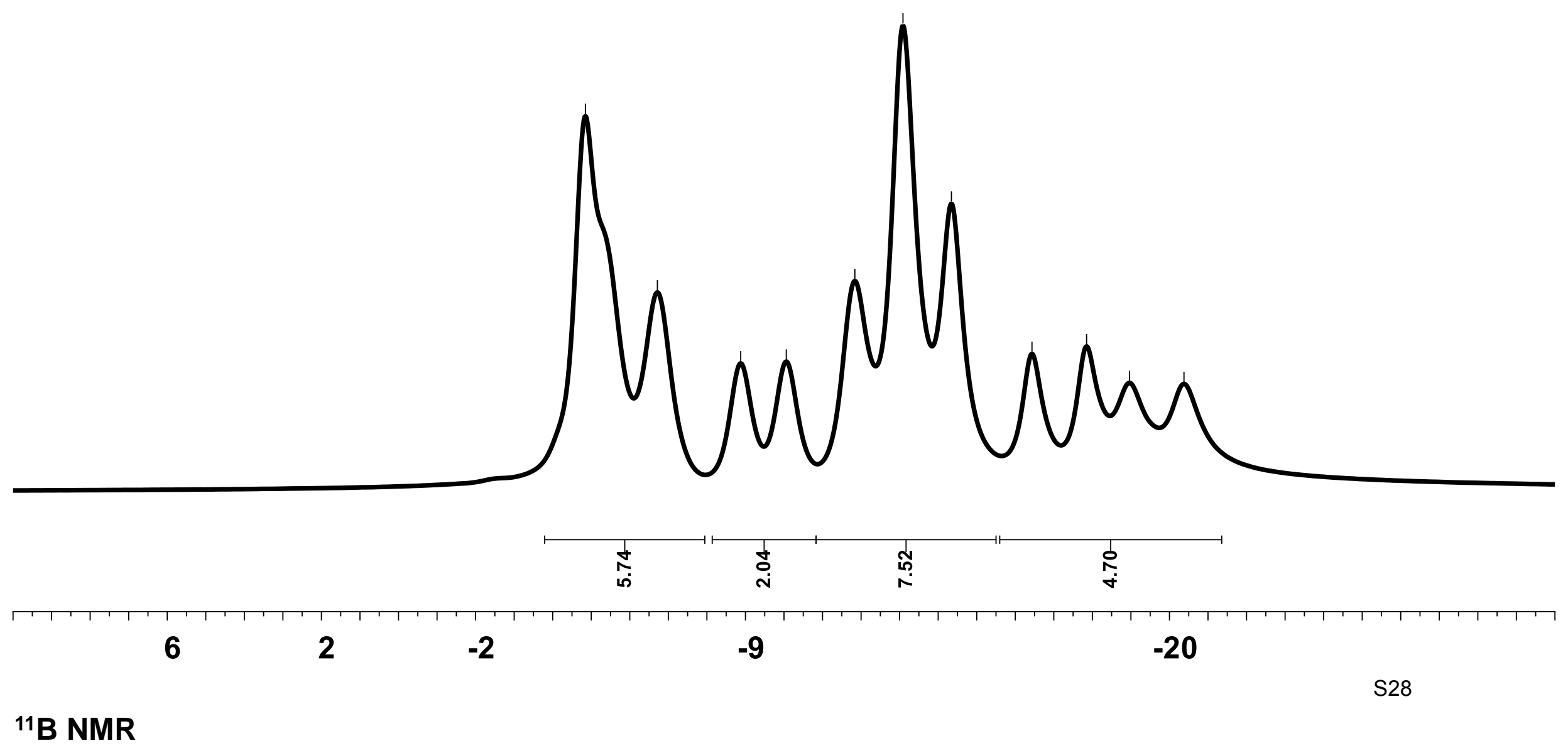



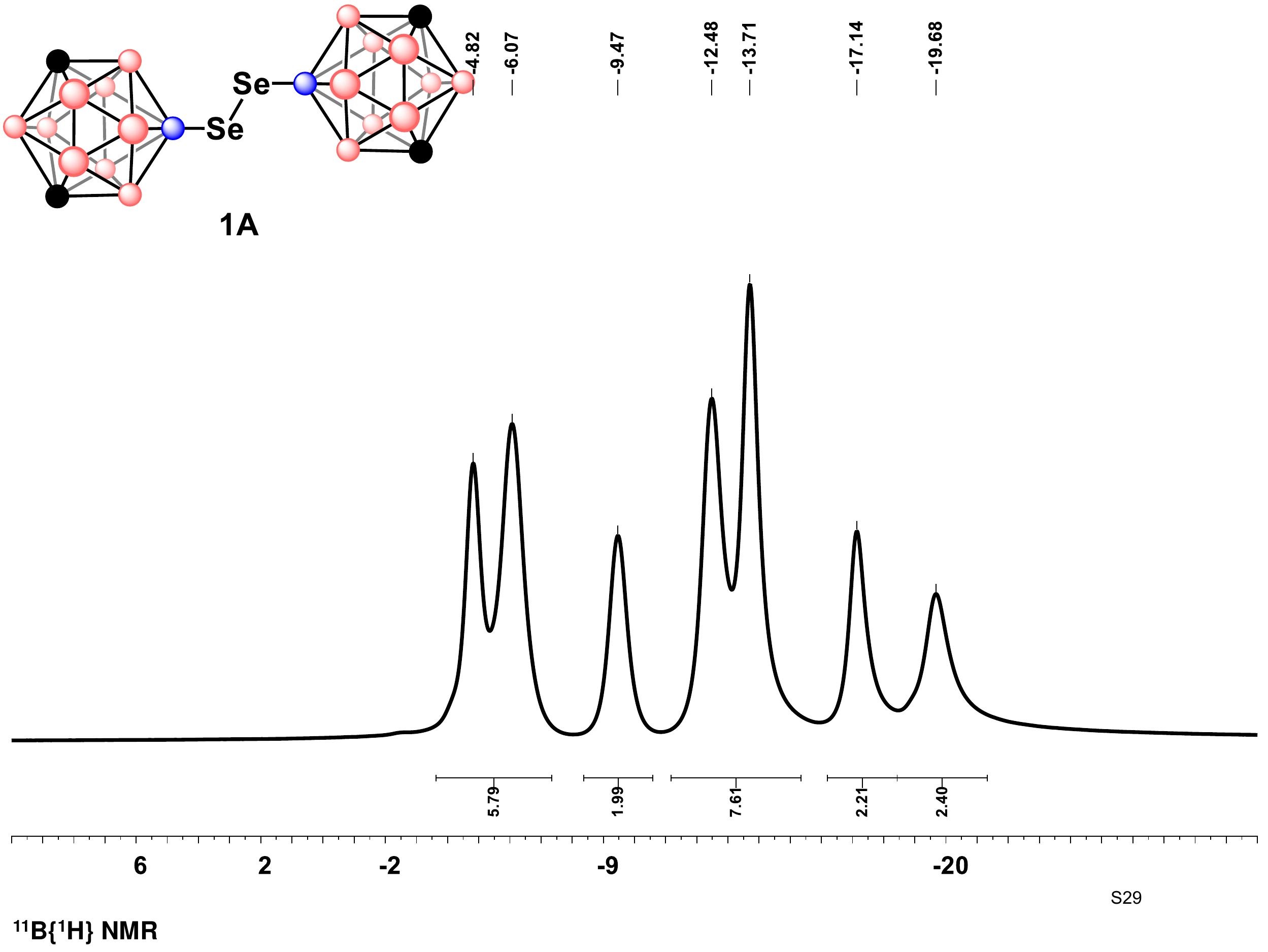


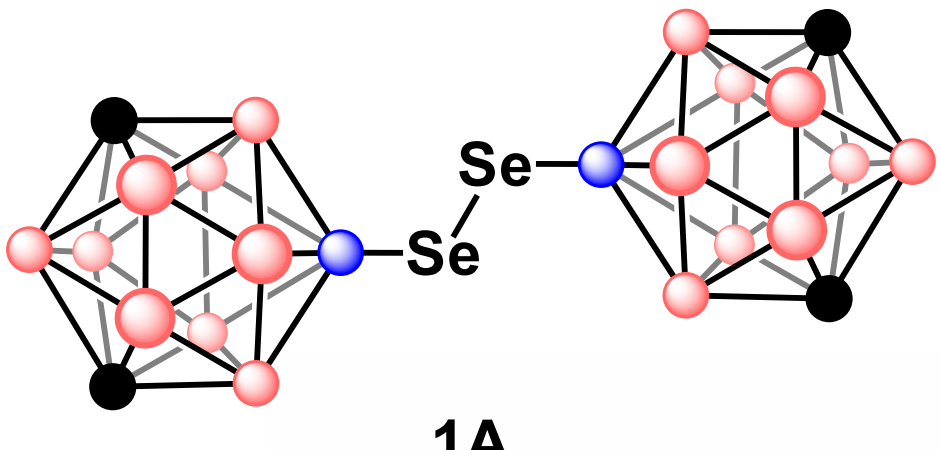

$1 \mathrm{~A}$

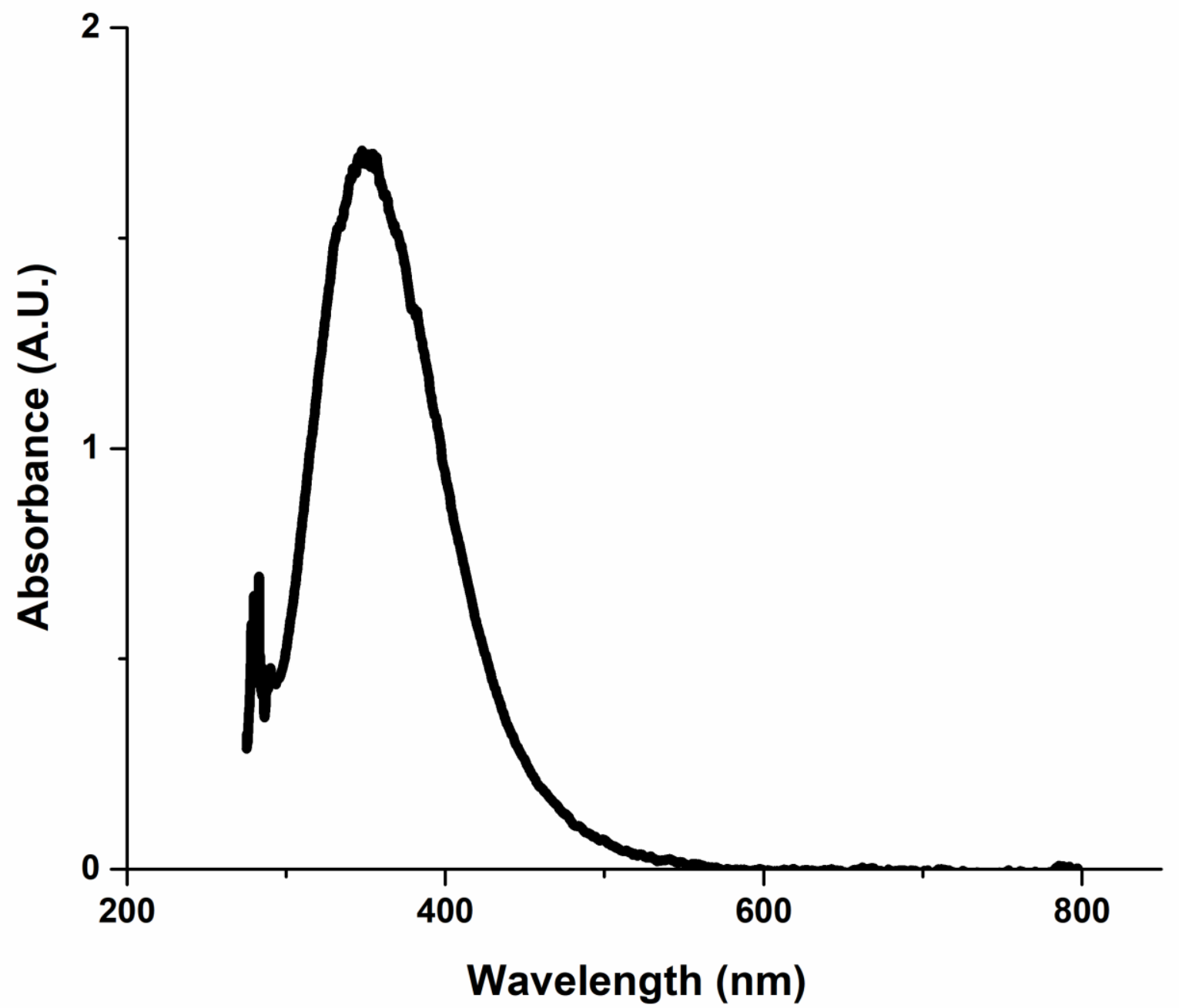

S32

UV-Vis 


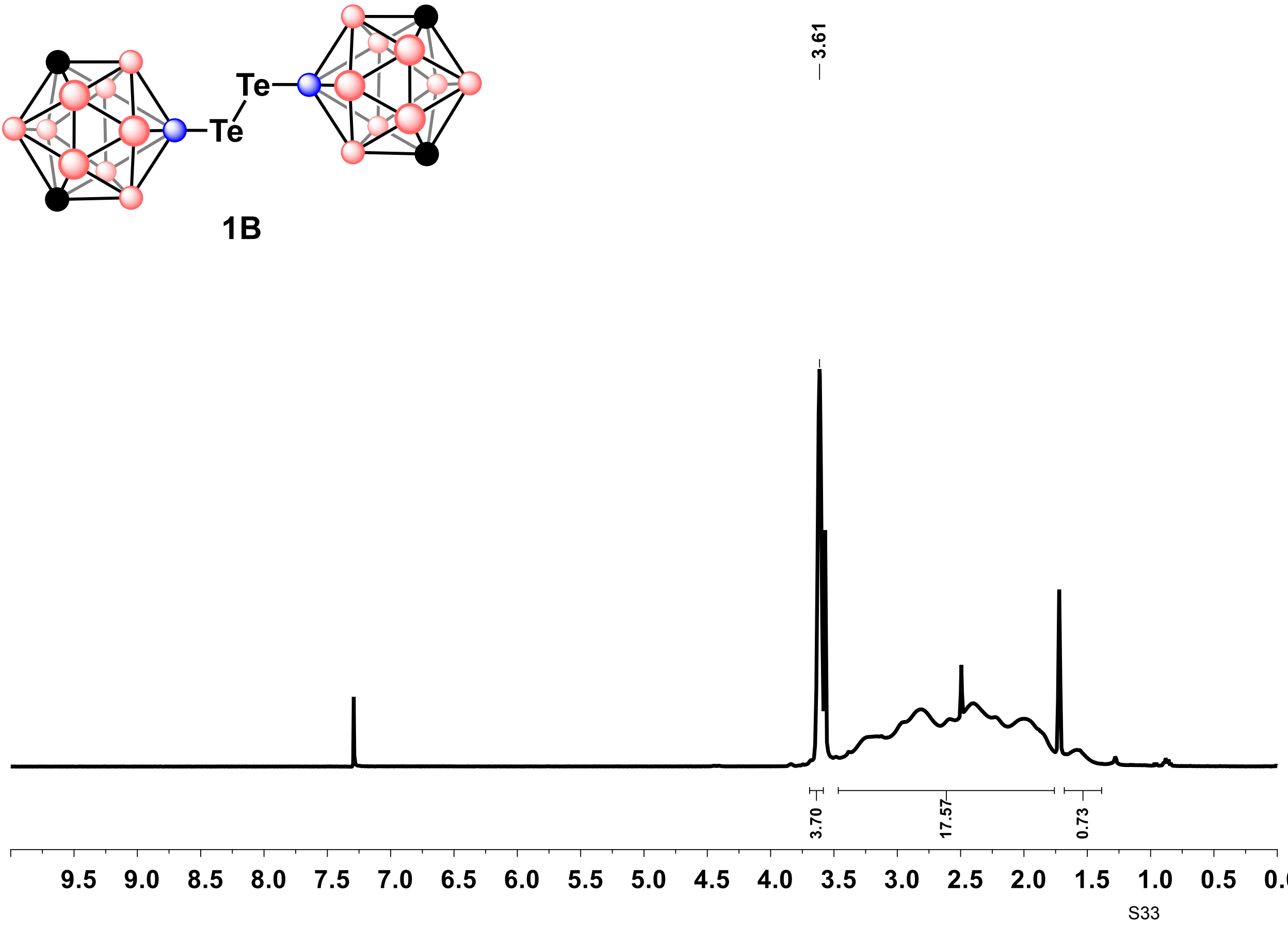
1H NMR 


$$
\text { Muldoll }
$$




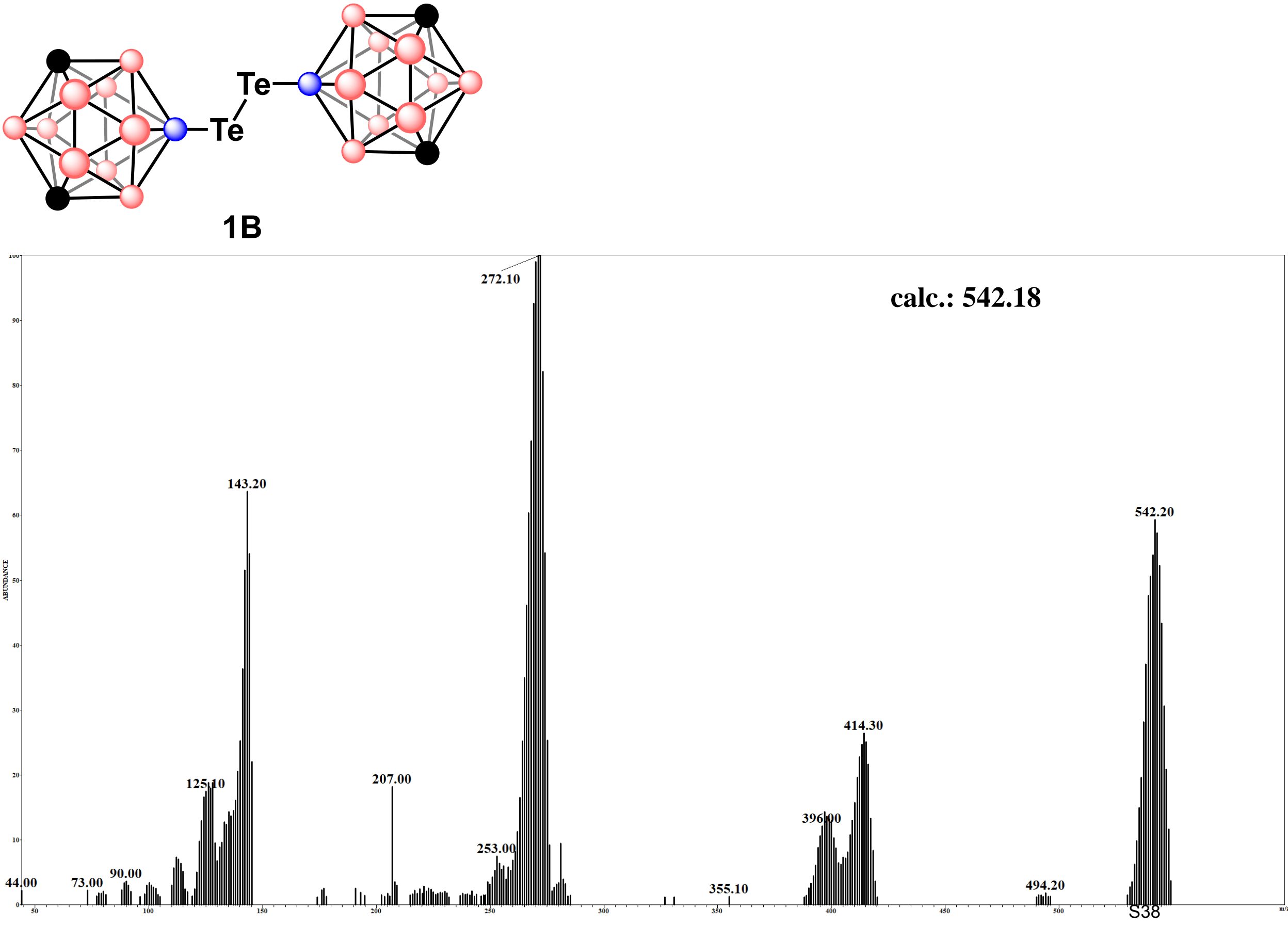

\section{GC-MS}




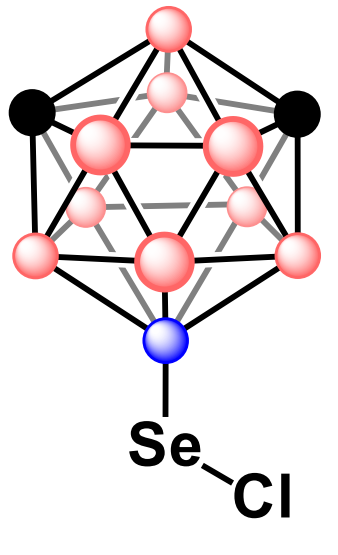

2A

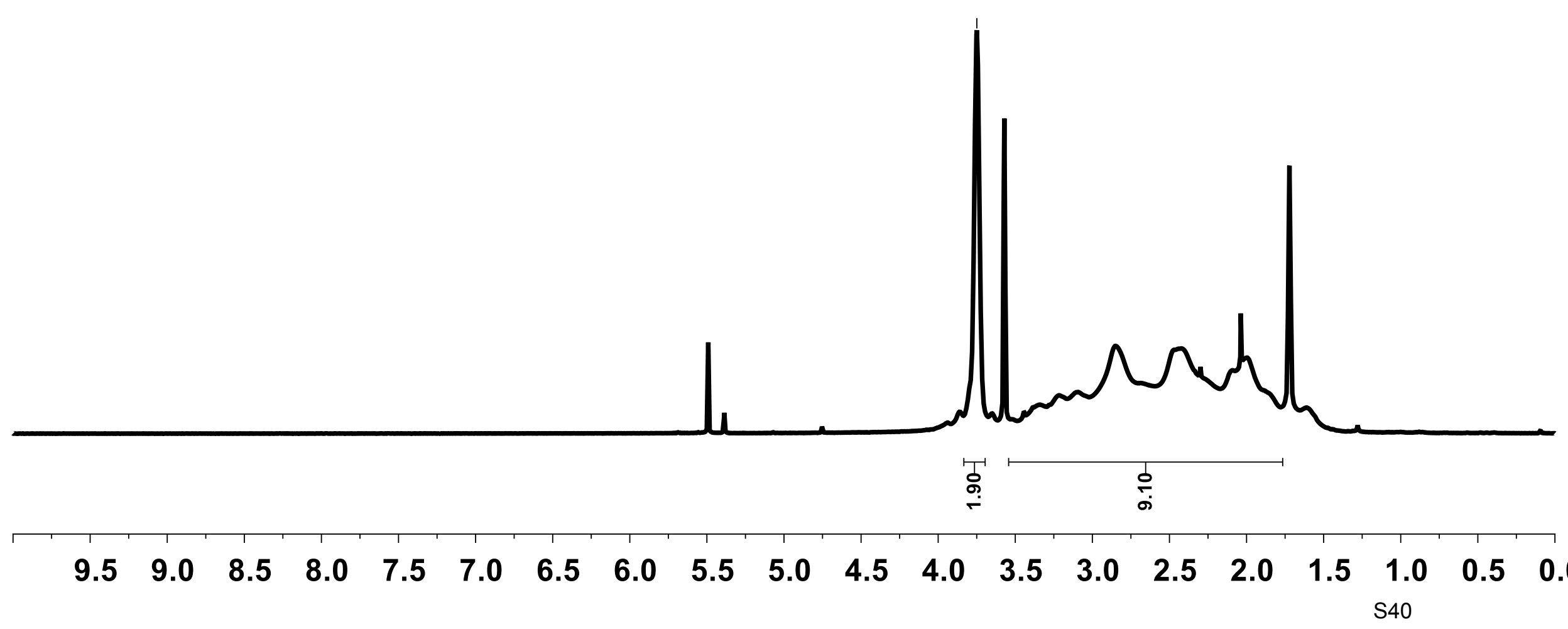
${ }^{1} \mathrm{H}$ NMR 


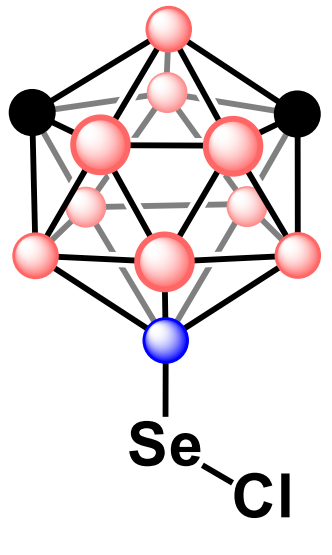

ต

$2 A$

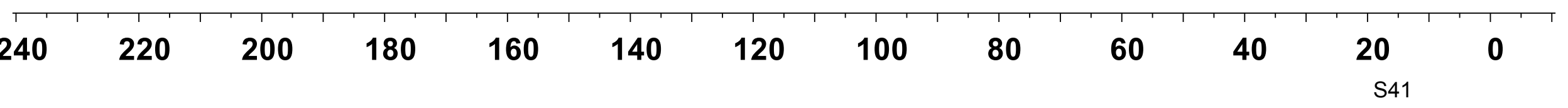
${ }^{13} \mathrm{C}\left\{{ }^{1} \mathrm{H}\right\}$ NMR 


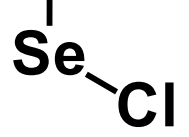

\section{$2 A$}

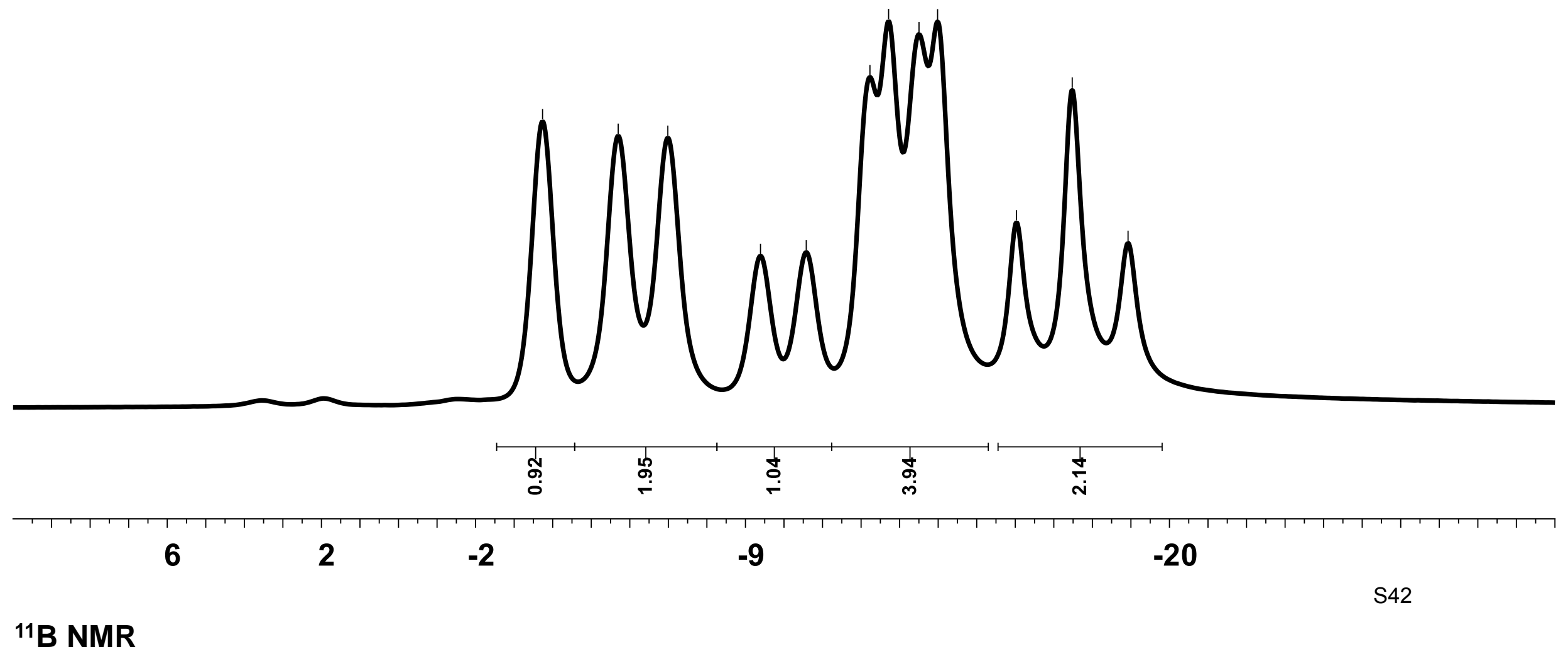




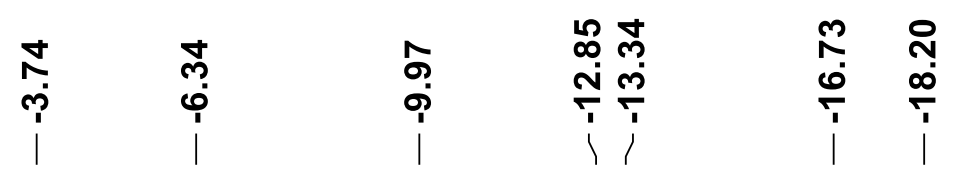

2A

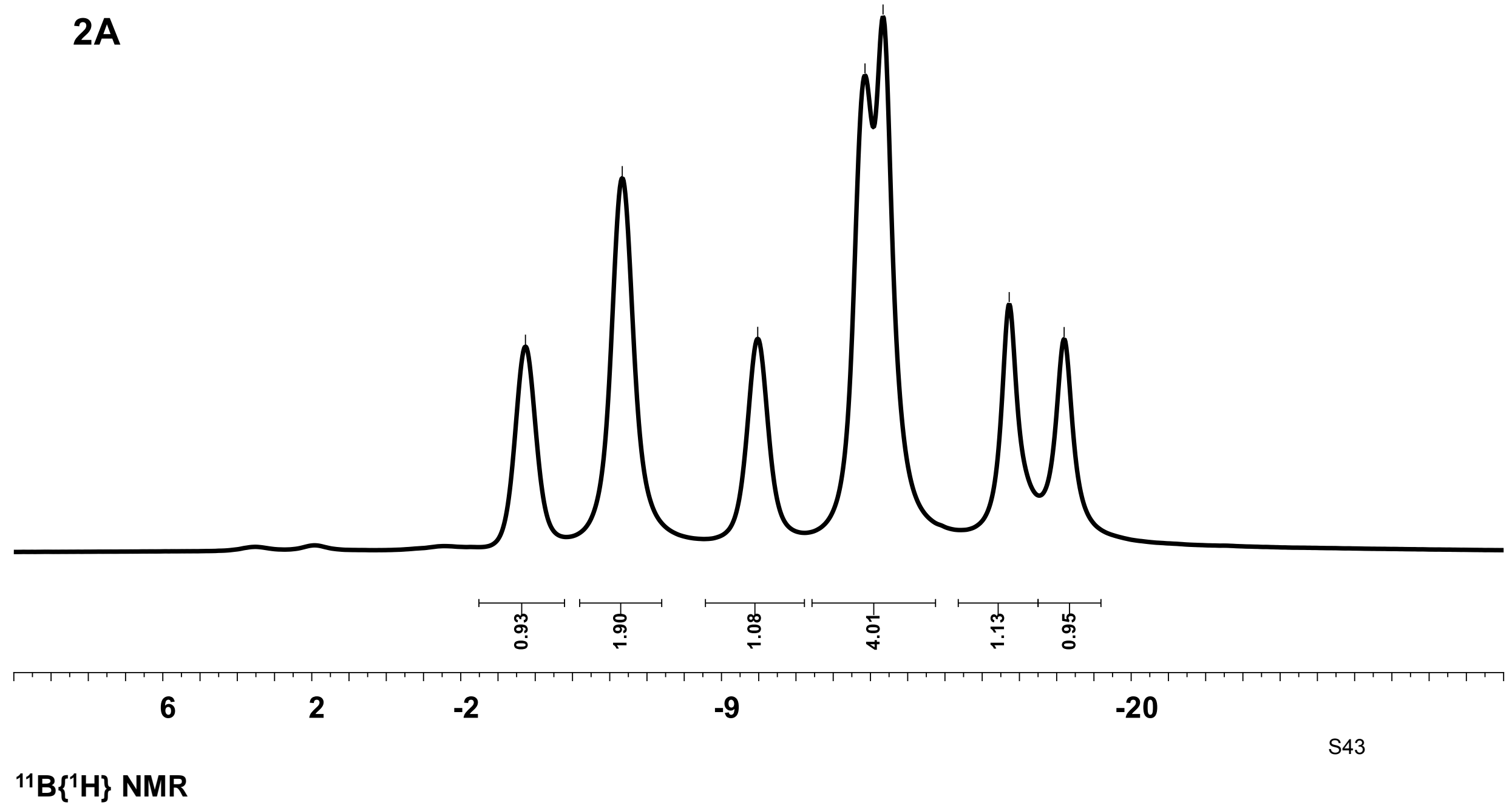




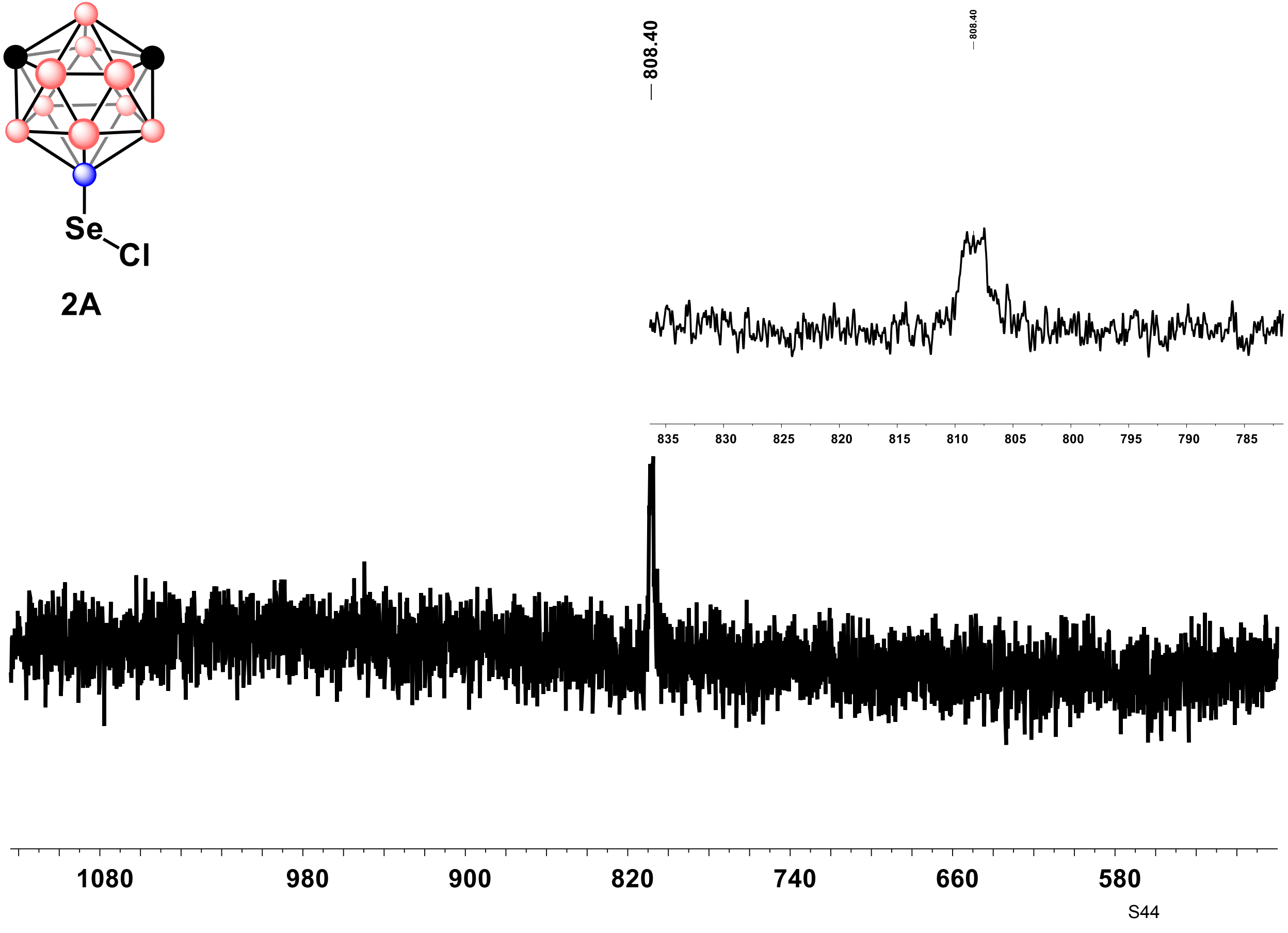




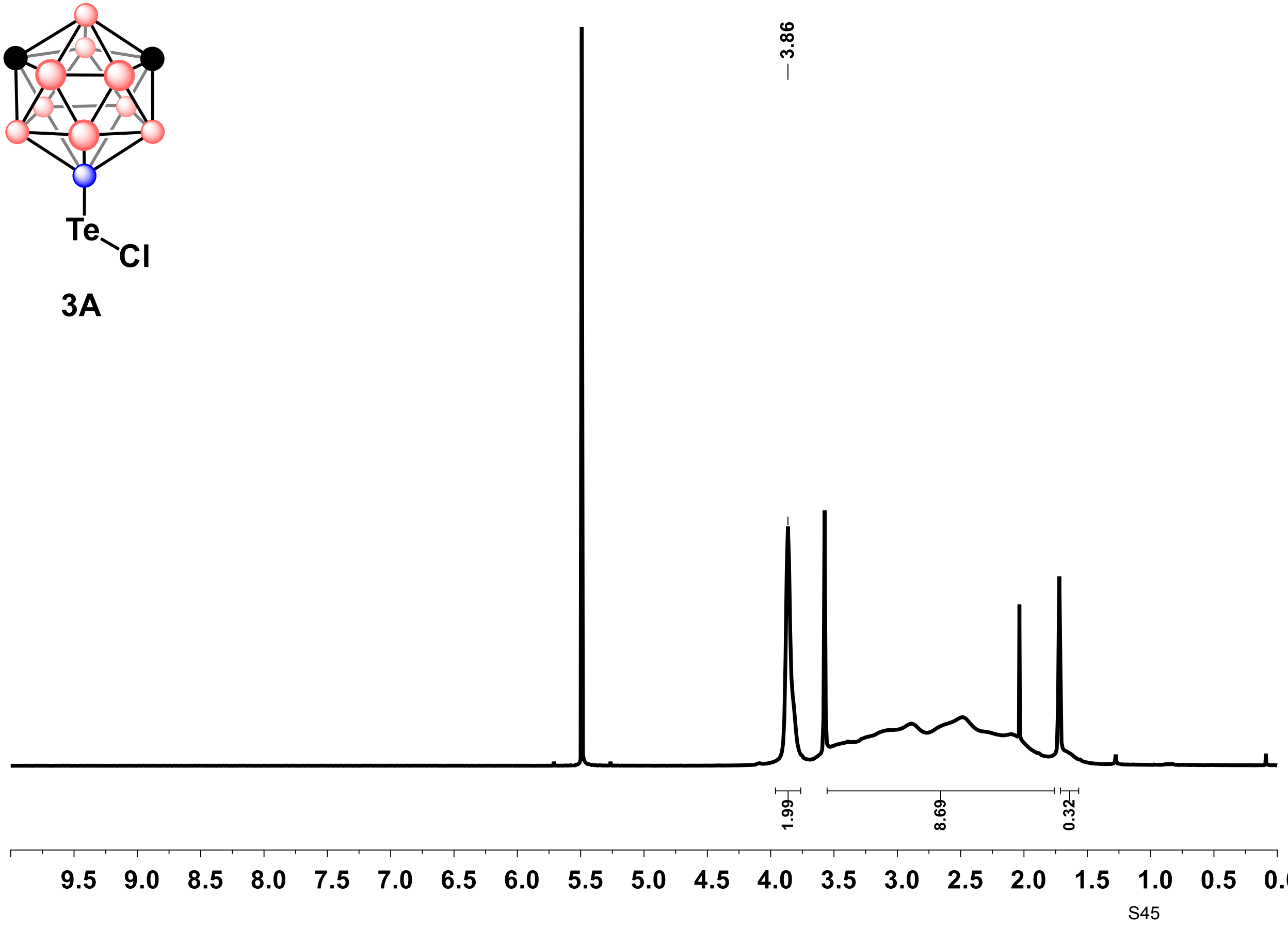
${ }^{1}$ H NMR 


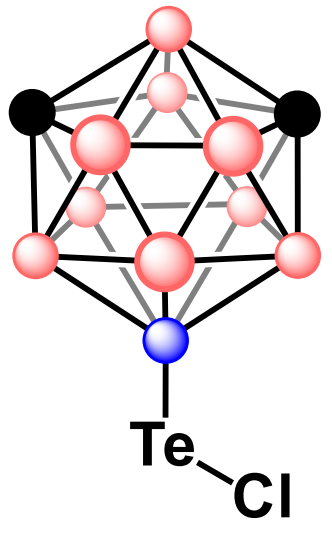

3A

\begin{tabular}{|c|c|c|c|c|c|c|c|c|c|c|c|}
\hline 220 & 200 & 180 & 160 & 140 & 120 & 100 & 80 & 60 & 40 & $\begin{array}{c}20 \\
S 46\end{array}$ & 0 \\
\hline
\end{tabular}
${ }^{13} \mathrm{C}\left\{{ }^{1} \mathrm{H}\right\}$ NMR 


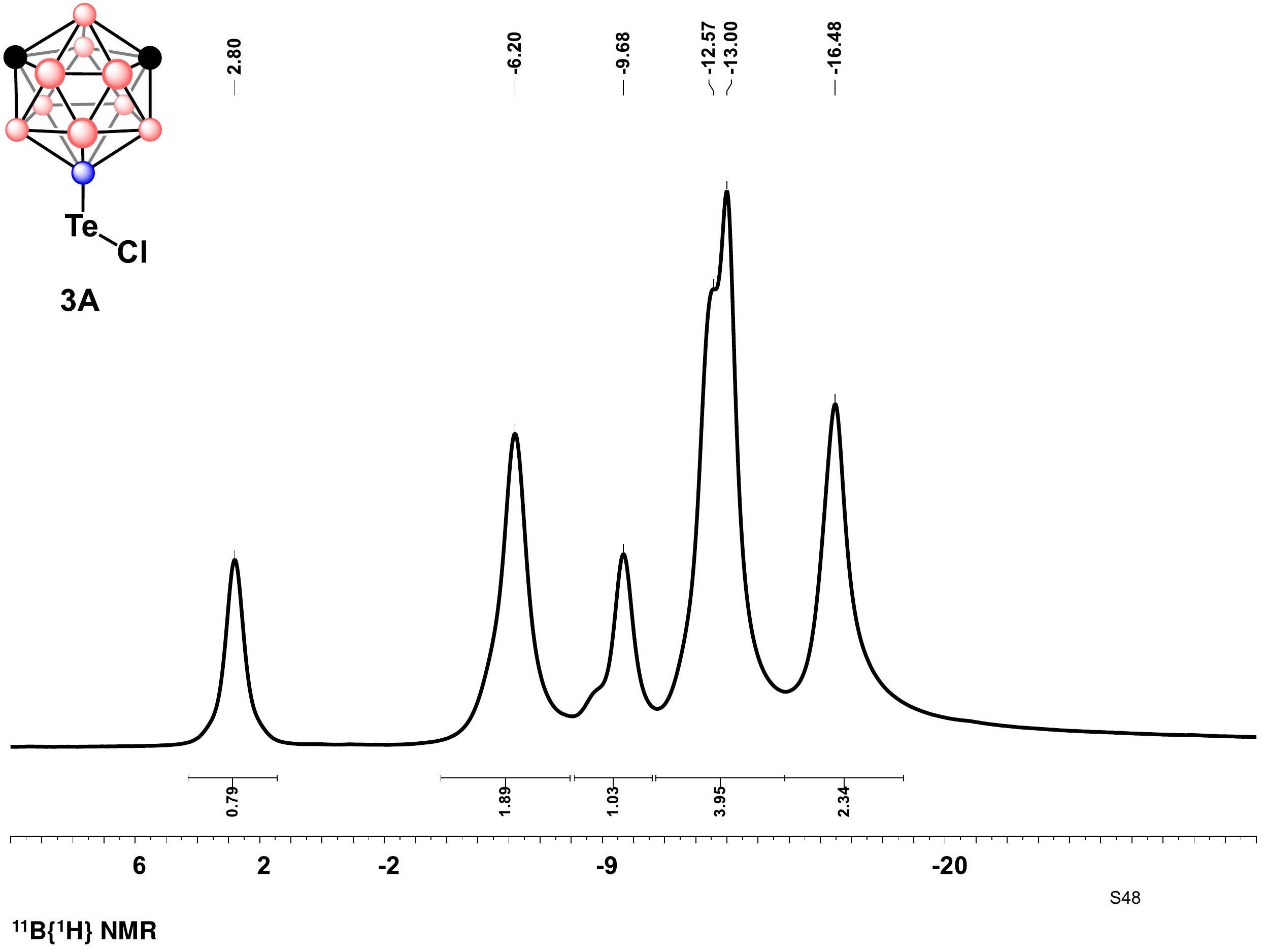



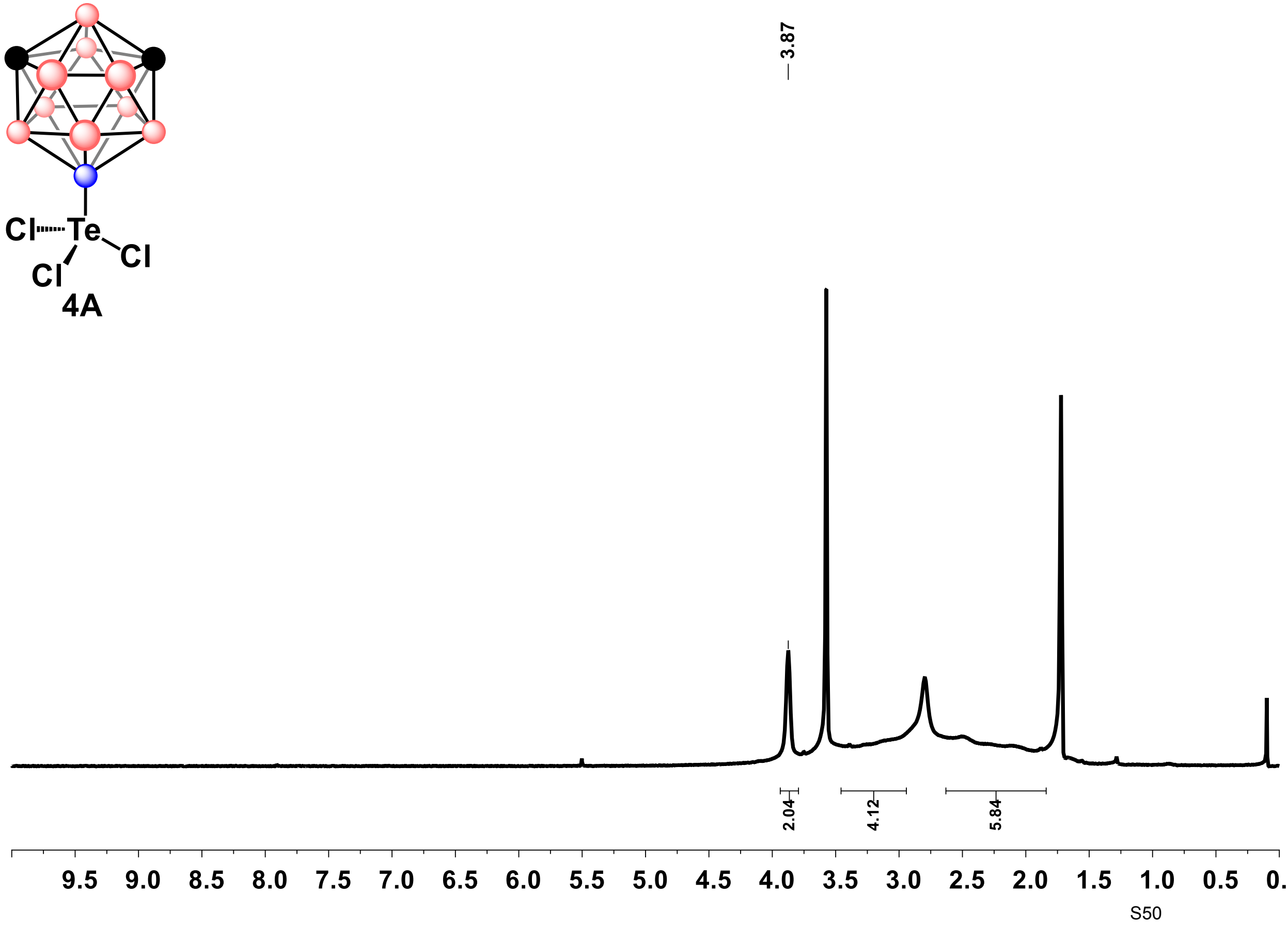
${ }^{1} \mathrm{H}$ NMR 

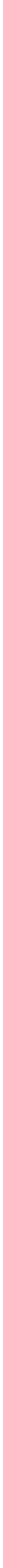


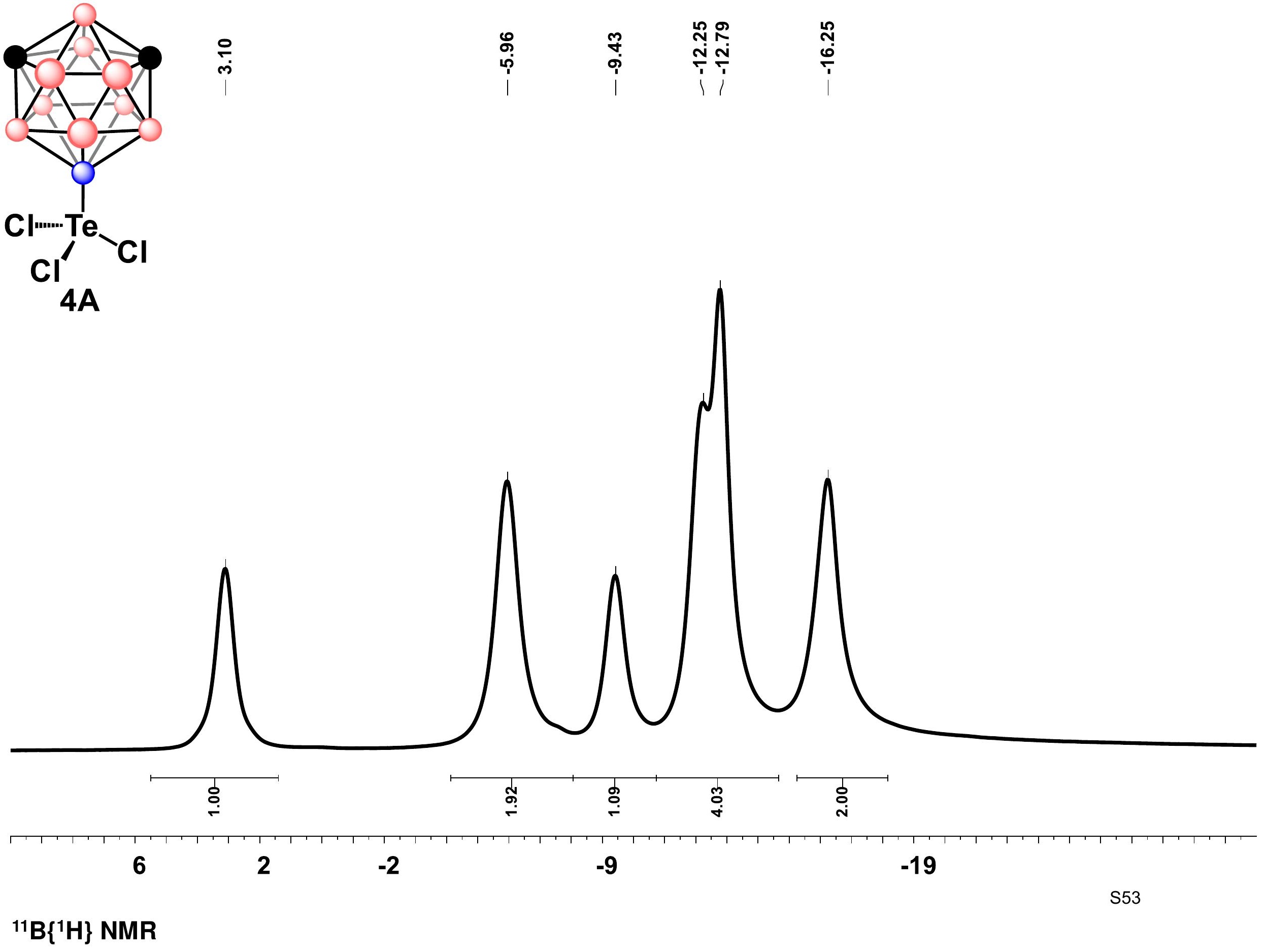



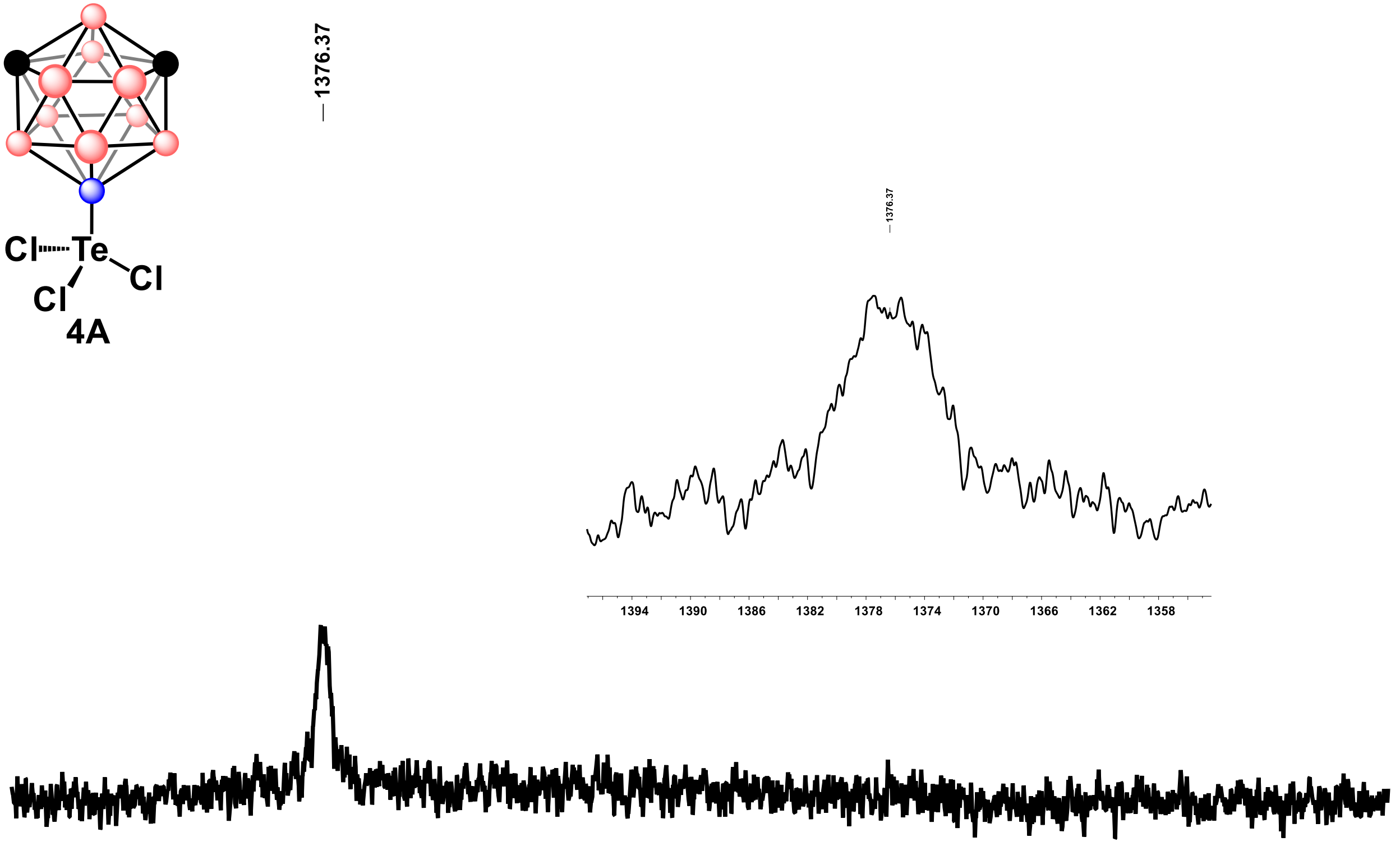

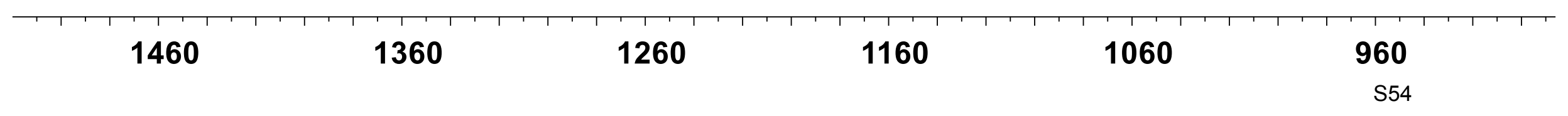
${ }^{125}$ Te NMR 


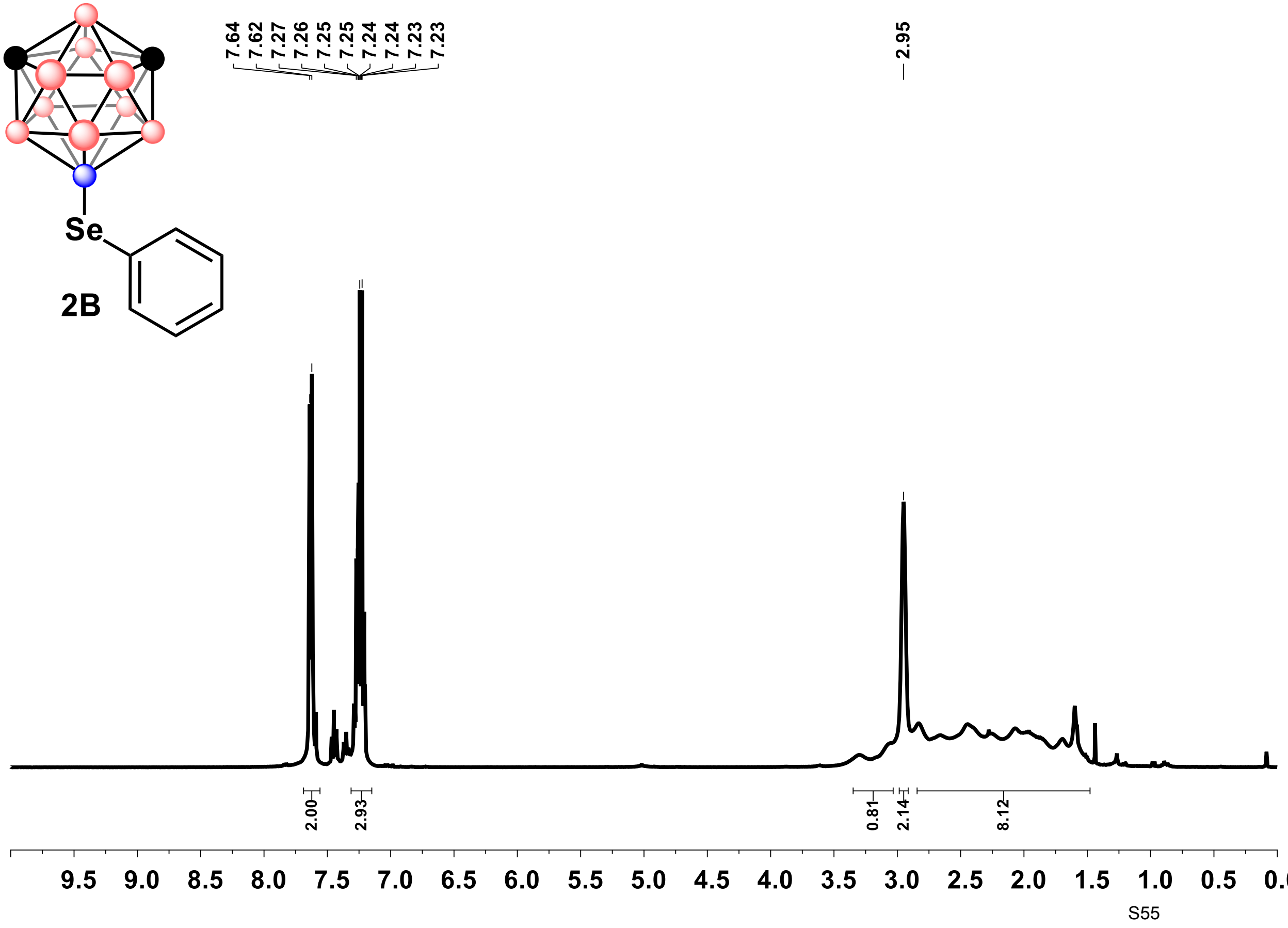
1H NMR 


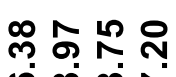

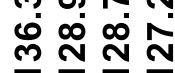

in

$-2$

।

Se

2B<smiles>Cc1ccccc1</smiles>

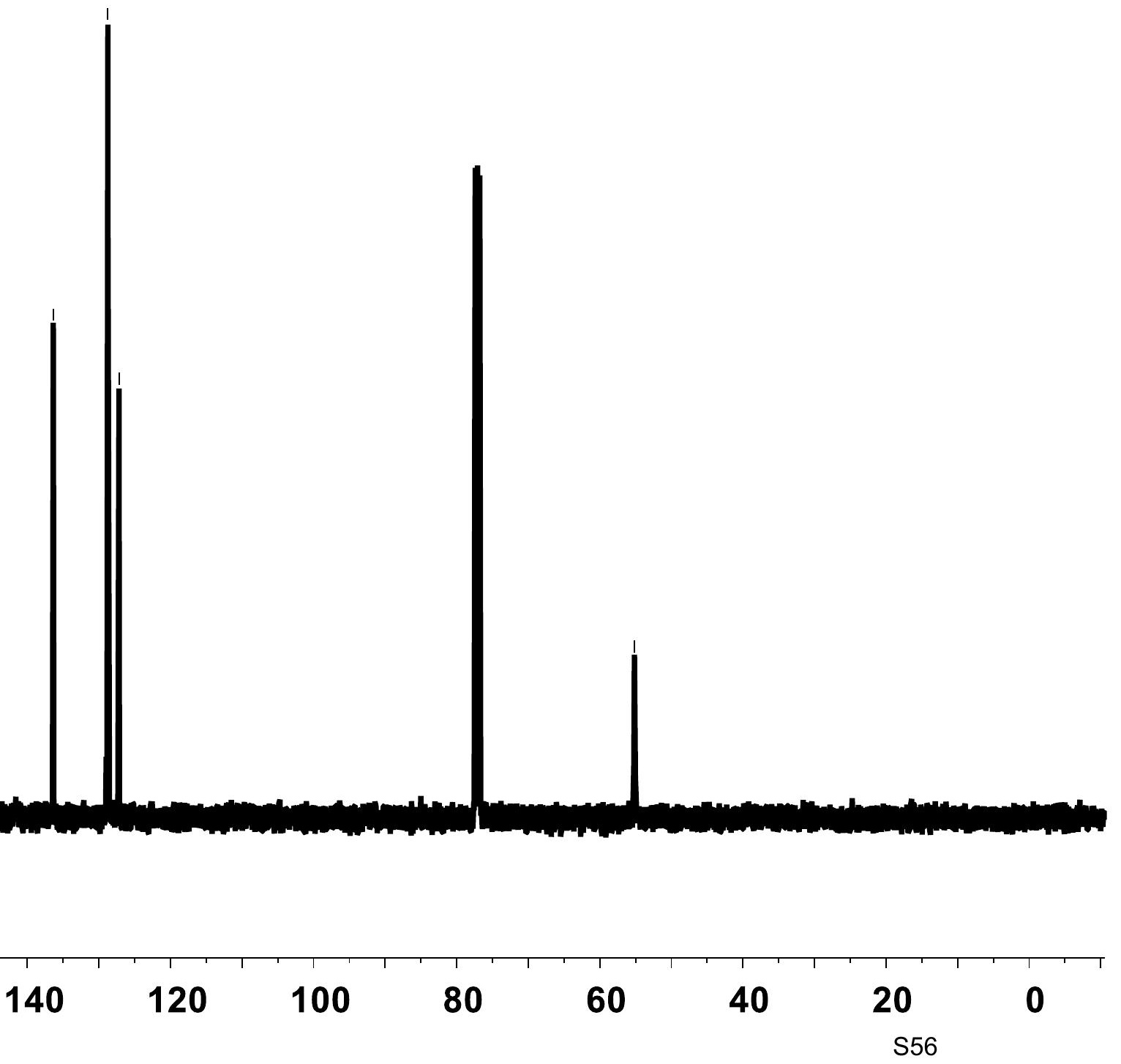

${ }^{13} \mathrm{C}\left\{{ }^{1} \mathrm{H}\right\}$ NMR 


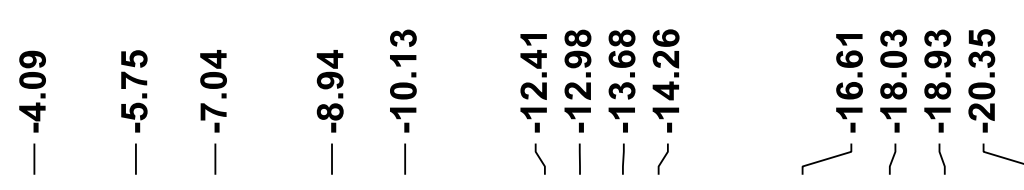<smiles>[Se]c1ccccc1</smiles>

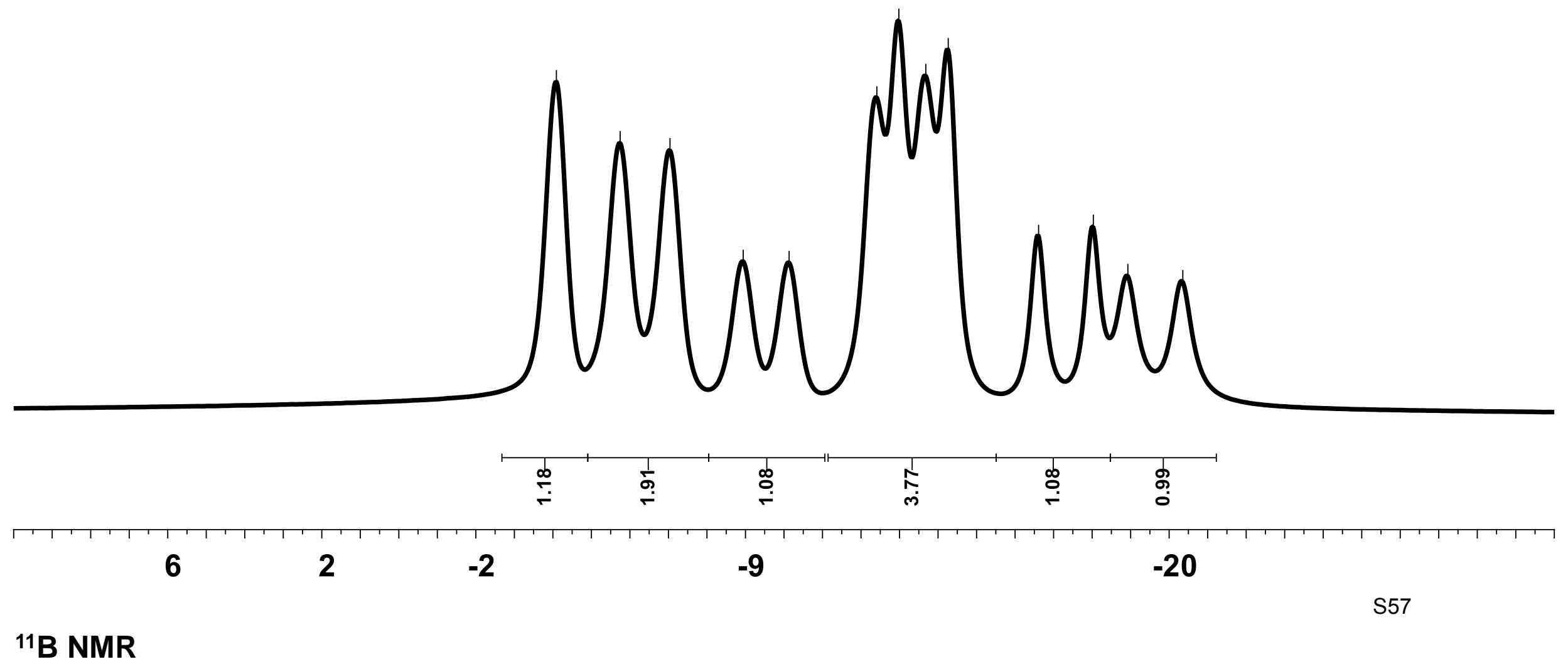


ธี

०

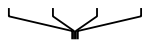
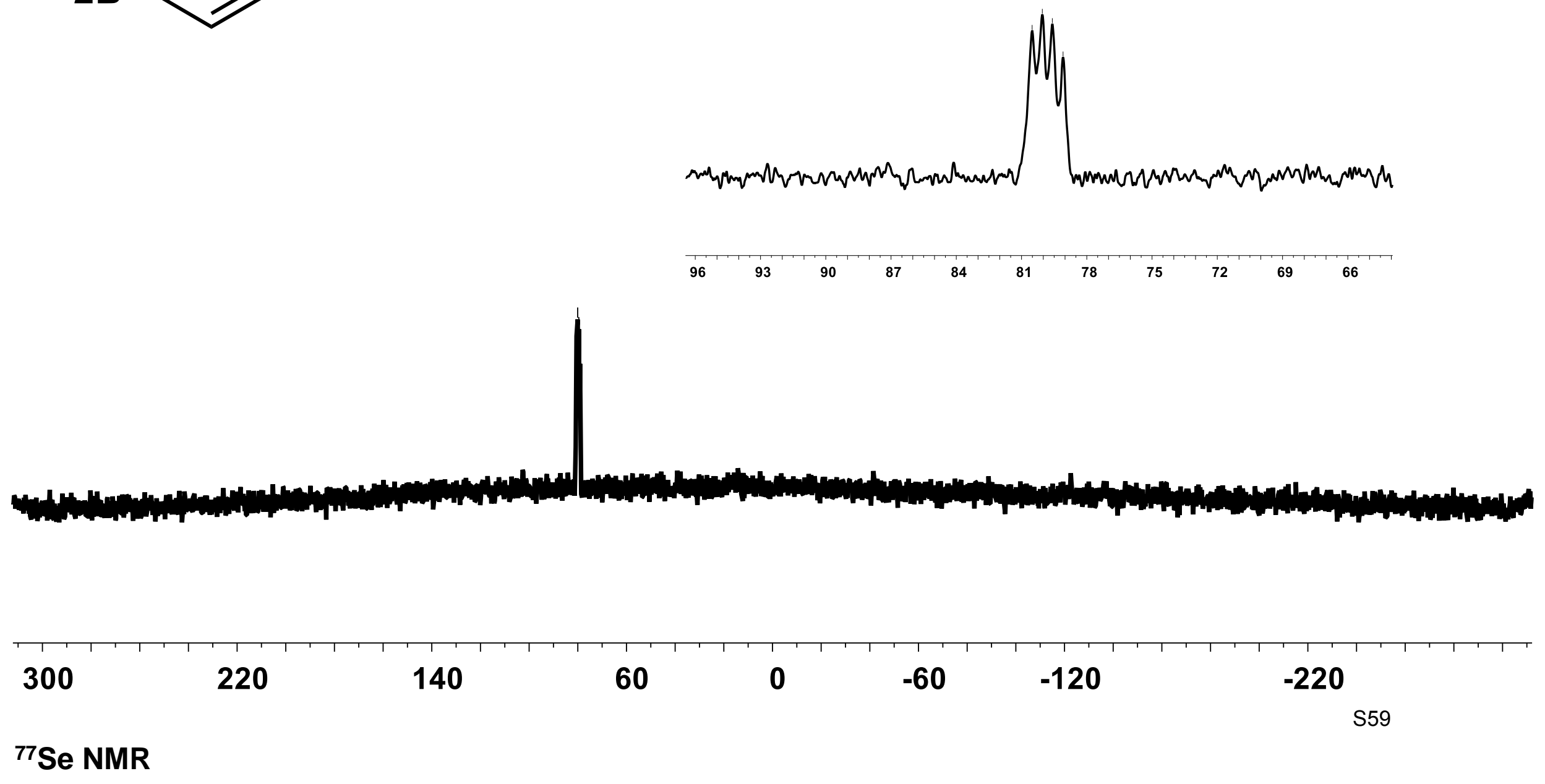


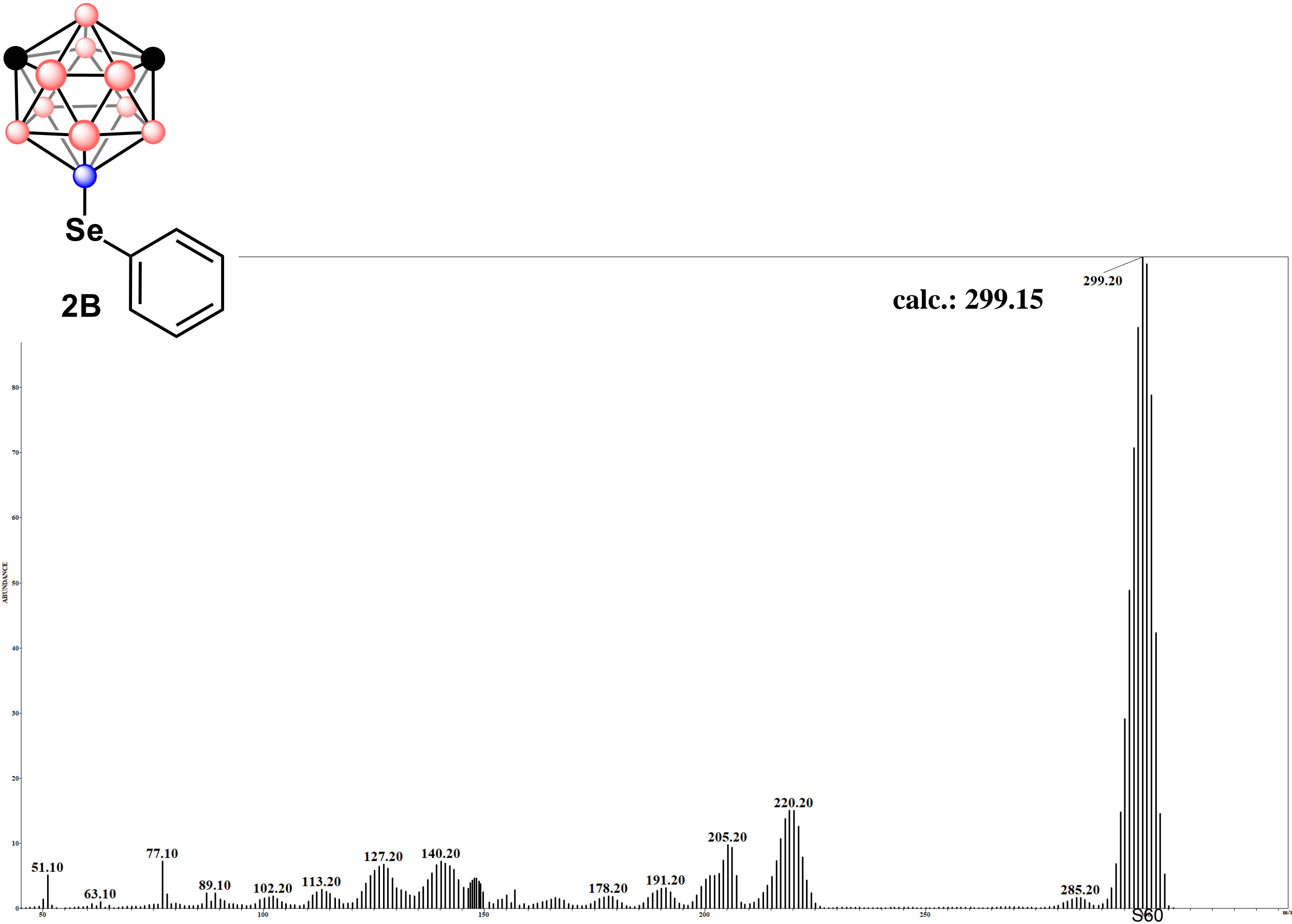
GC-MS 

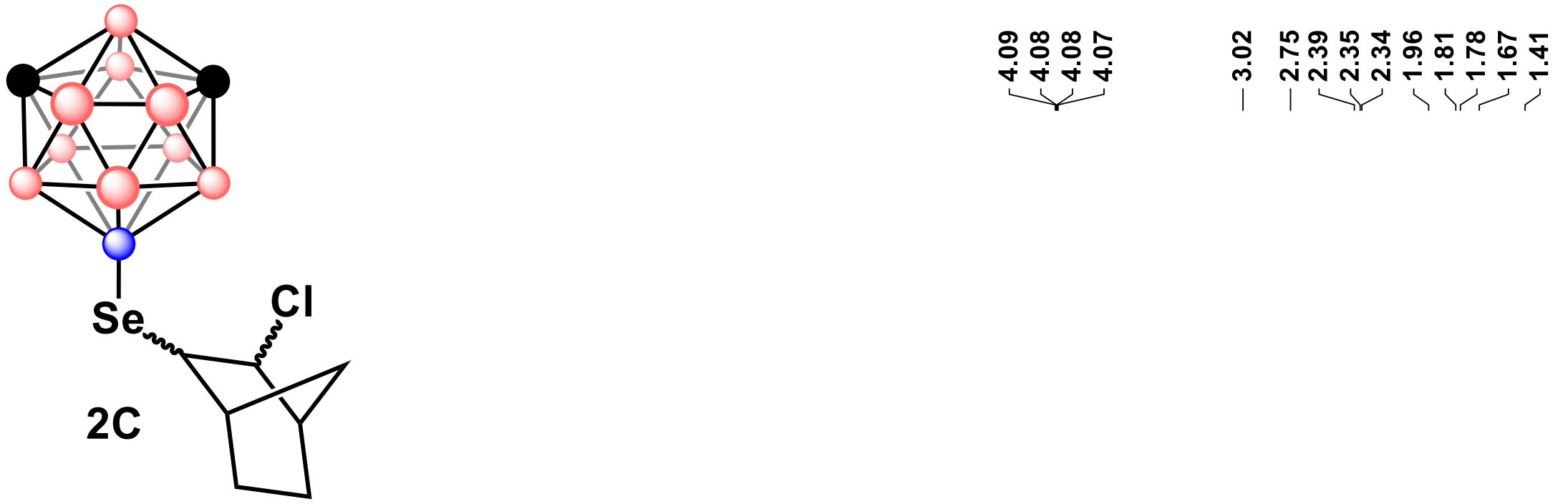

+ enantiomers

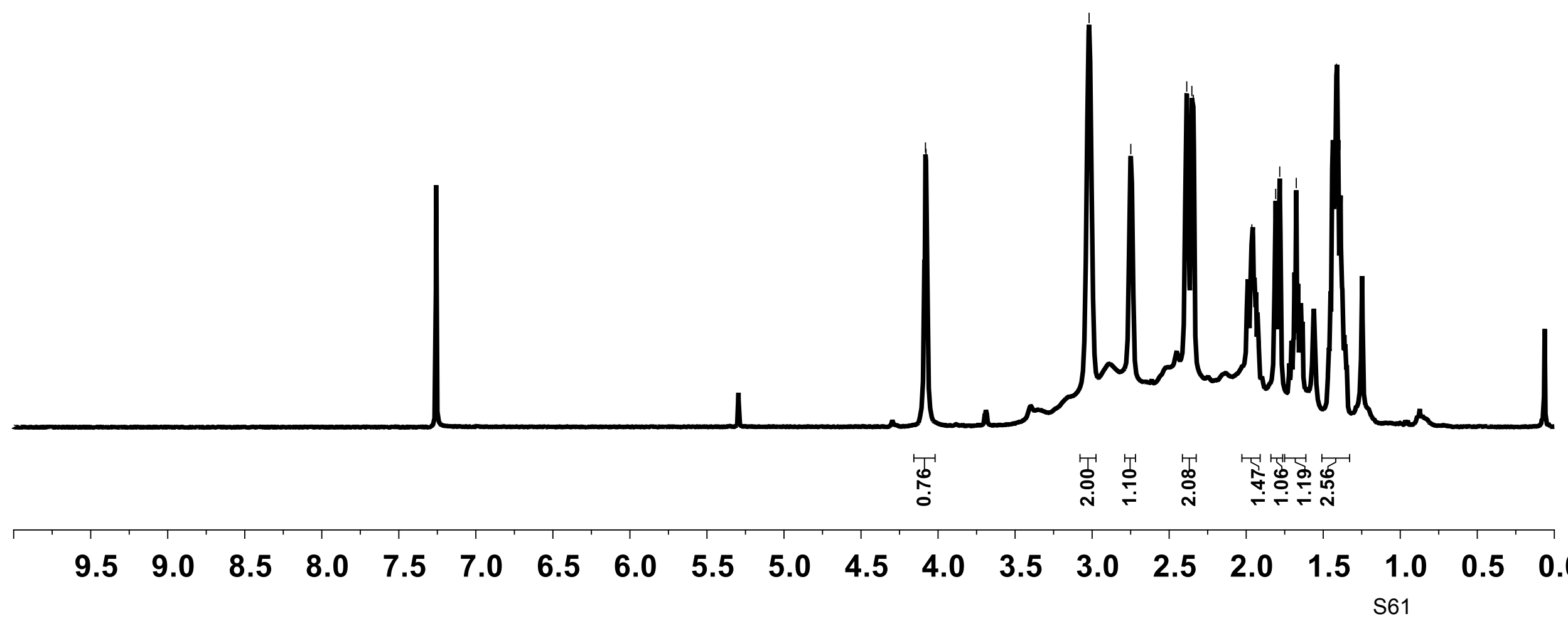
${ }^{1} \mathrm{H}$ NMR 


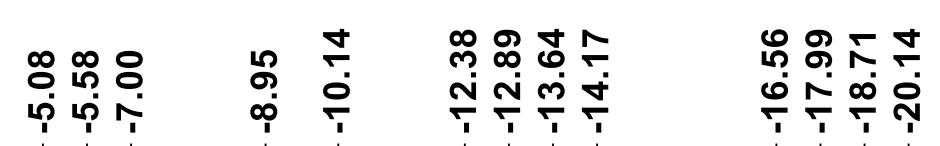

20

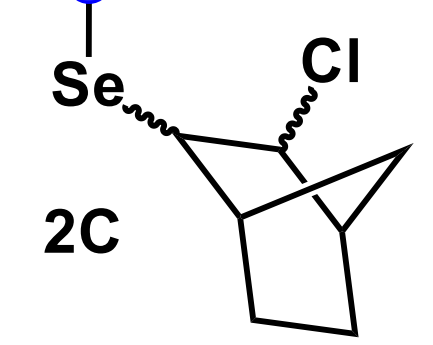

+ enantiomers

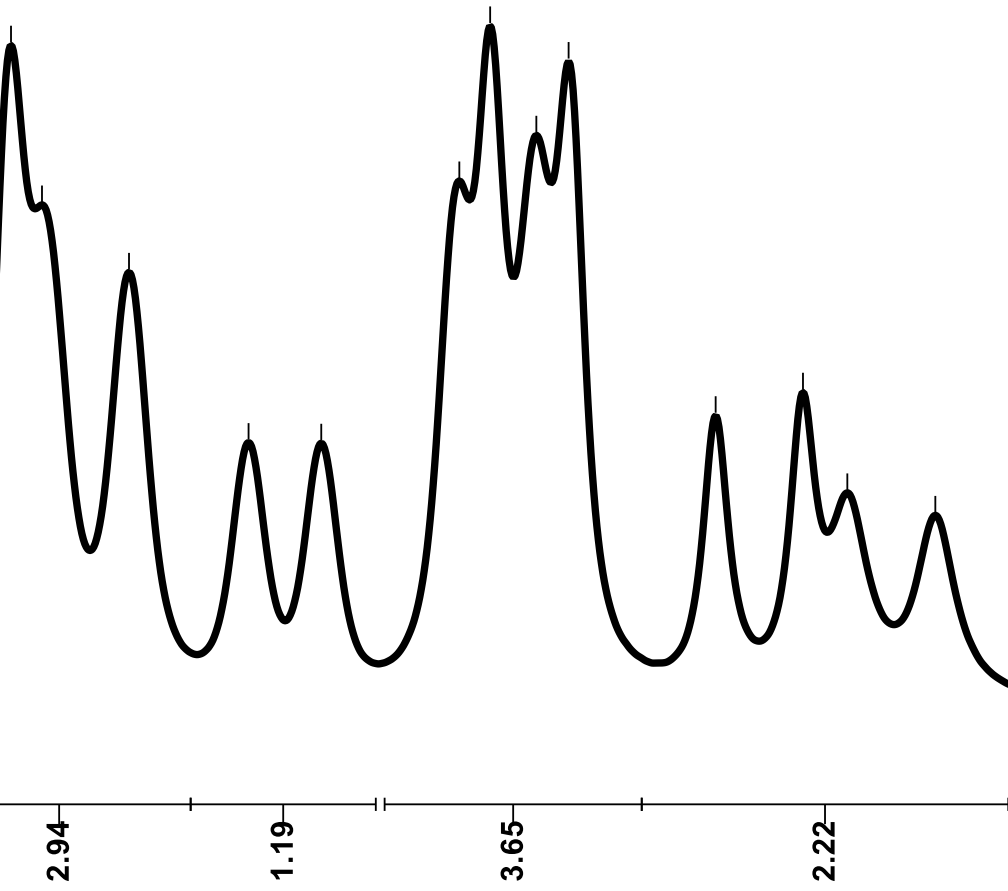

6

2

$-2$

$-9$

$-20$

${ }^{11}$ B NMR 

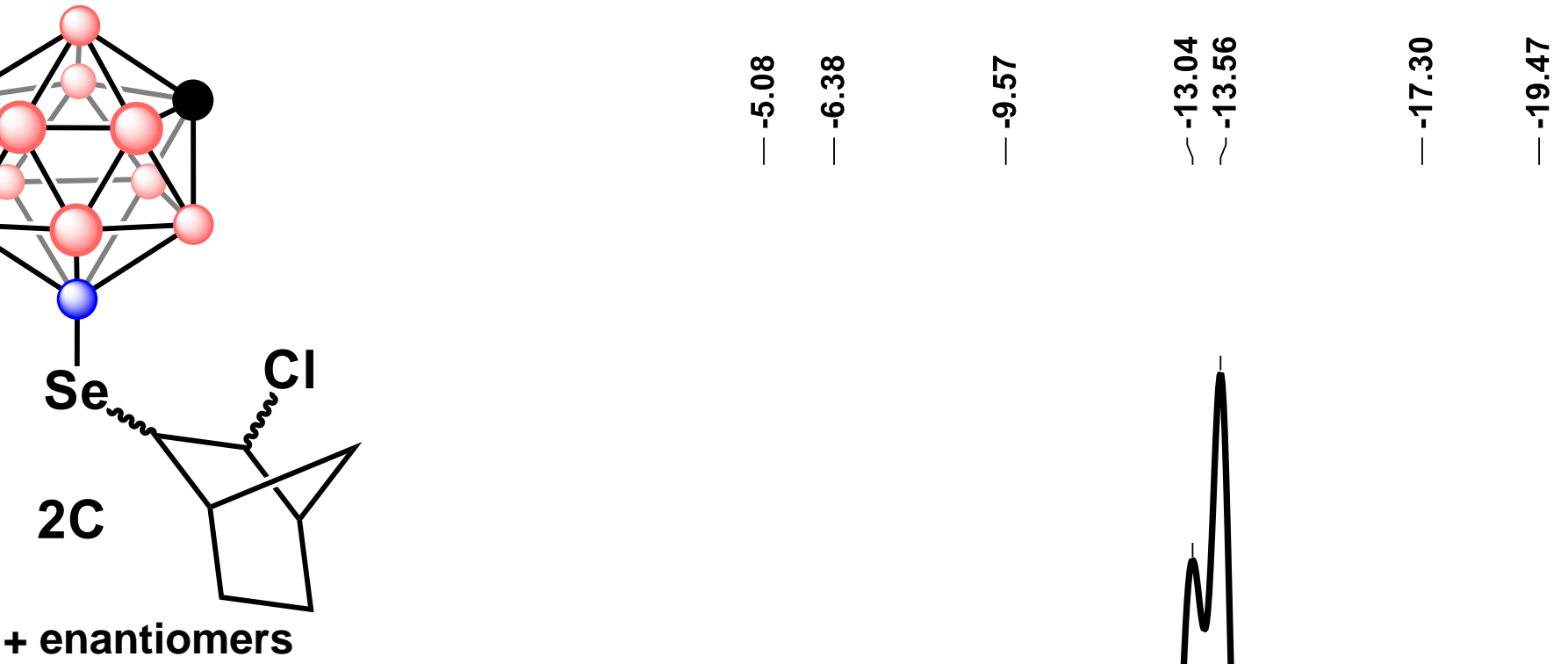


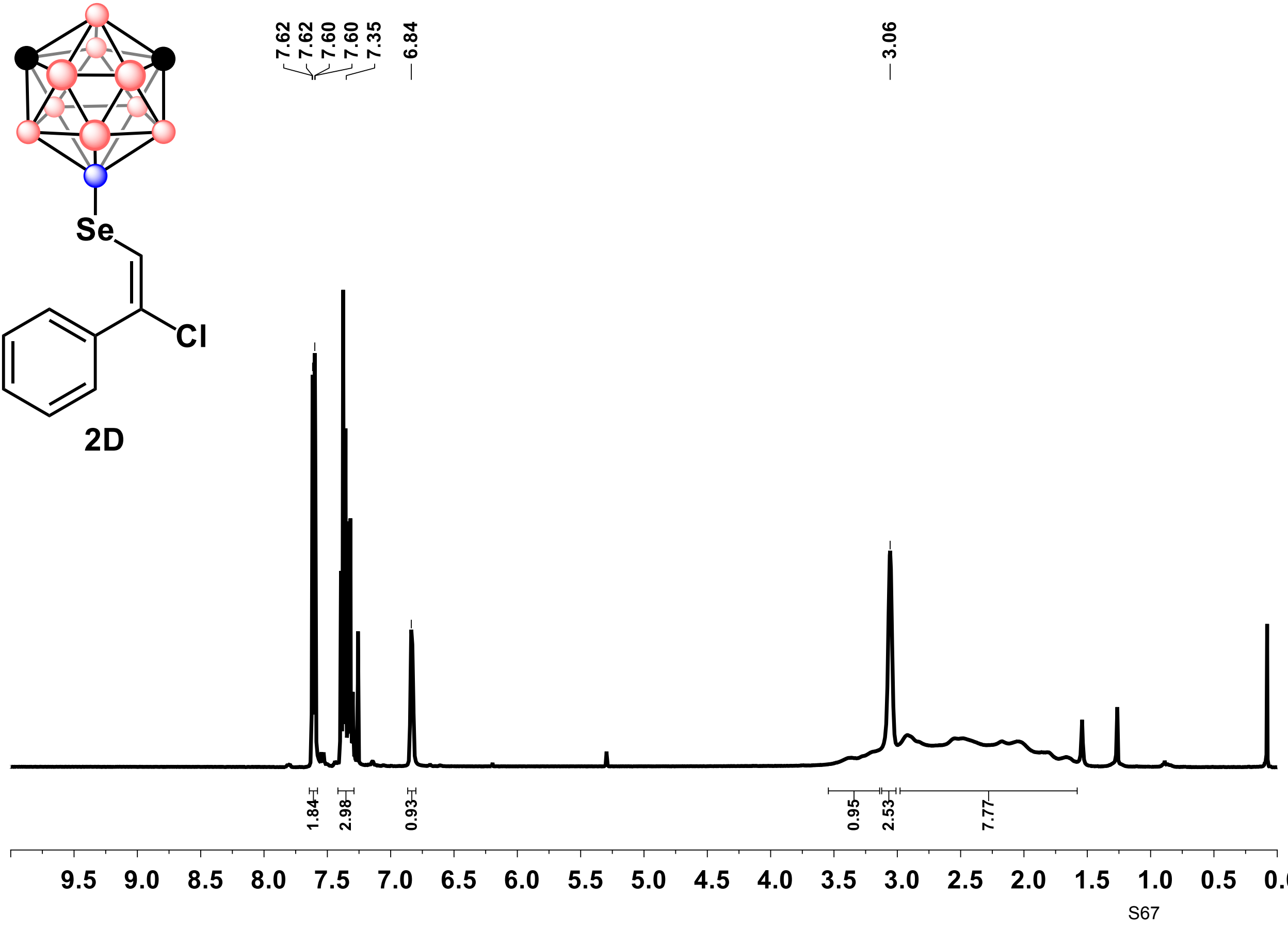
${ }^{1} \mathrm{H}$ NMR 


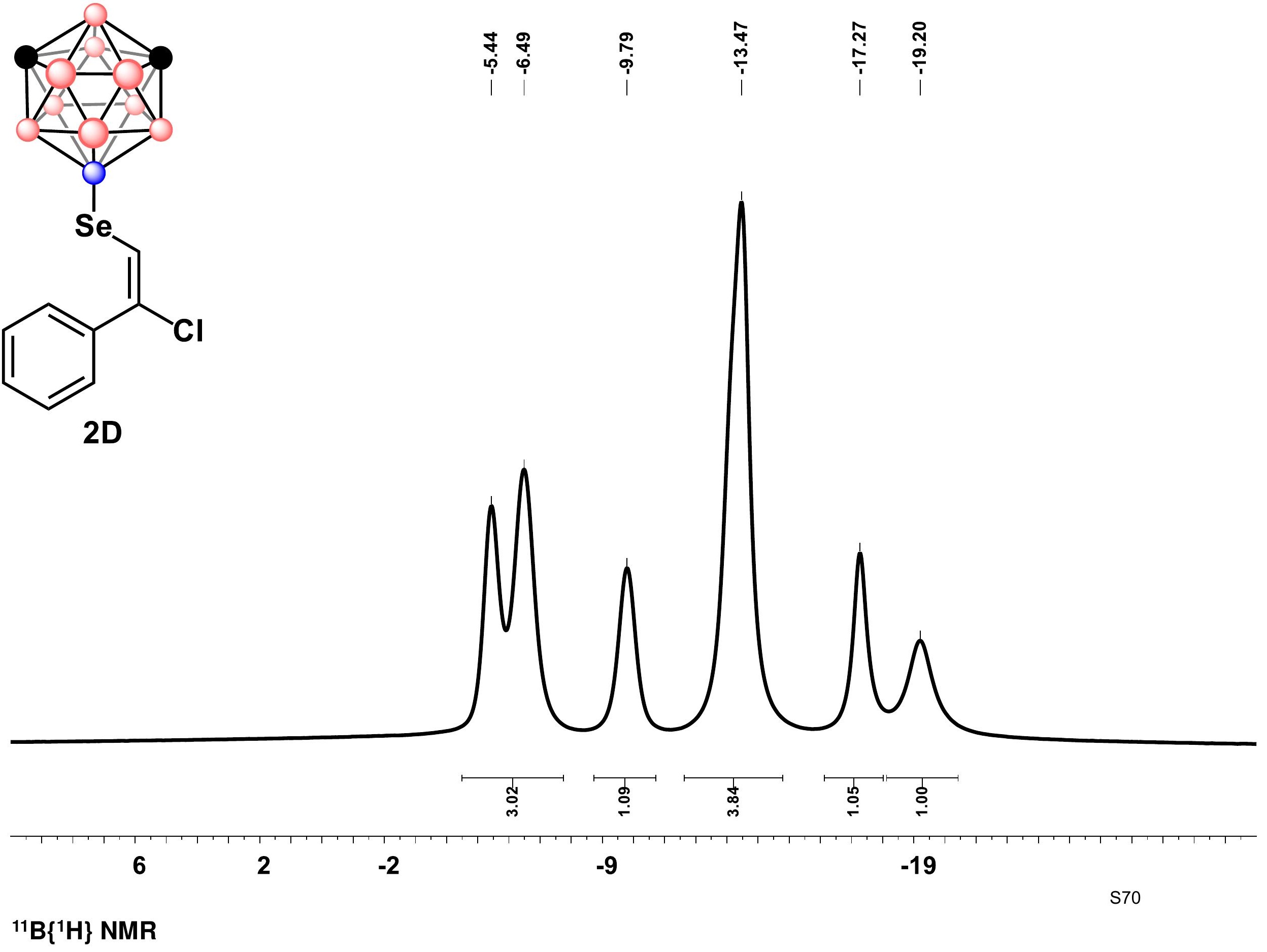




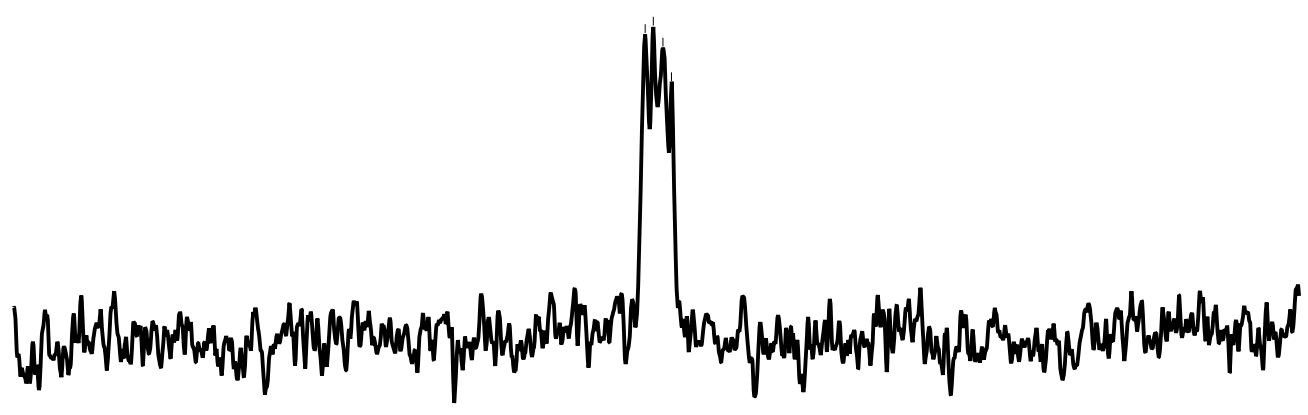

2D

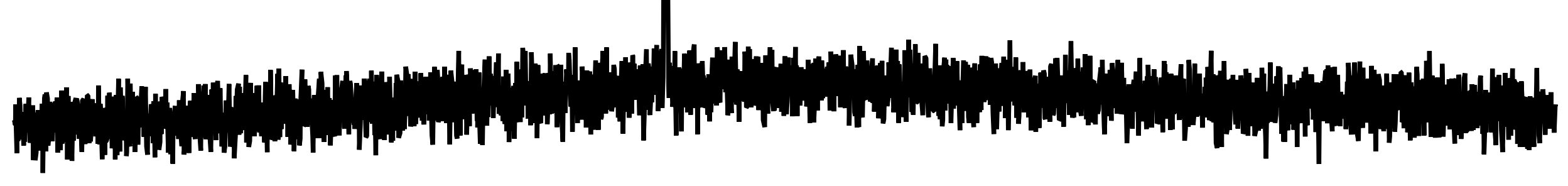

\begin{tabular}{|c|c|c|c|c|c|c|c|}
\hline 300 & 220 & 140 & 60 & 0 & -60 & -120 & $\begin{array}{r}-220 \\
S 71\end{array}$ \\
\hline
\end{tabular}

${ }^{77}$ Se NMR 


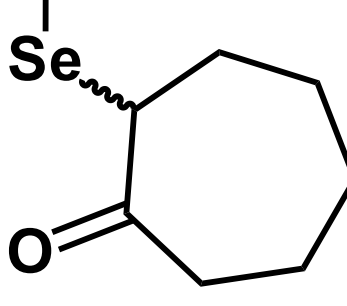

2E

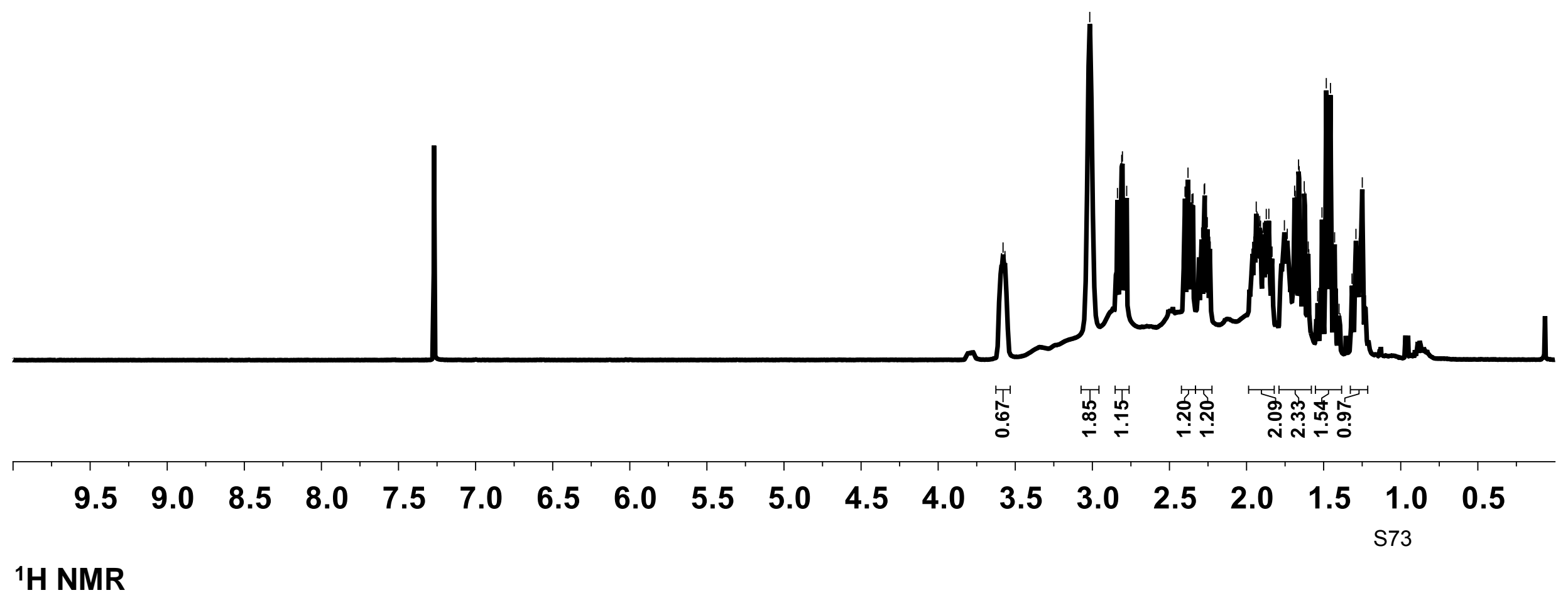




\begin{tabular}{|c|c|c|c|c|c|c|c|c|c|c|c|}
\hline 220 & 200 & 180 & 160 & 140 & 120 & 100 & 80 & 60 & 40 & $\begin{array}{r}20 \\
S 7\end{array}$ & 0 \\
\hline
\end{tabular}
${ }^{13} \mathrm{C}\left\{{ }^{1} \mathrm{H}\right\}$ NMR 


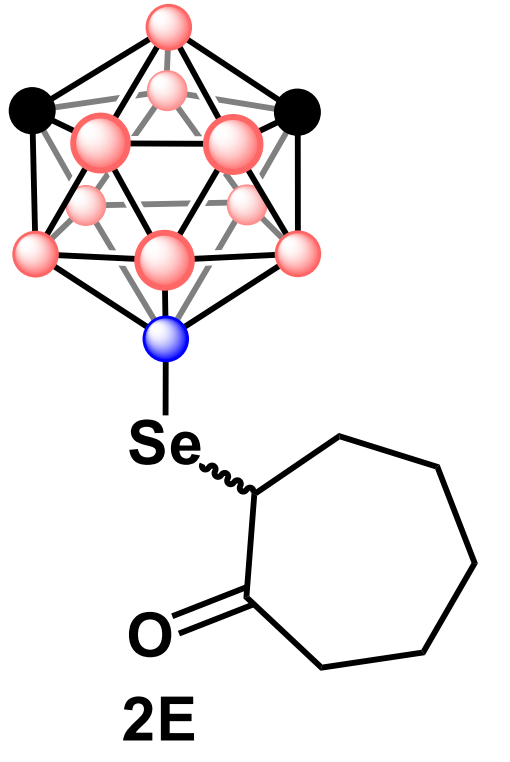

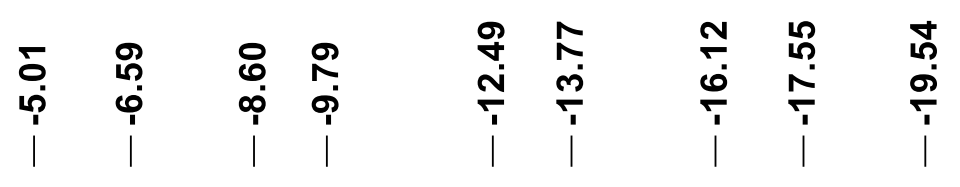
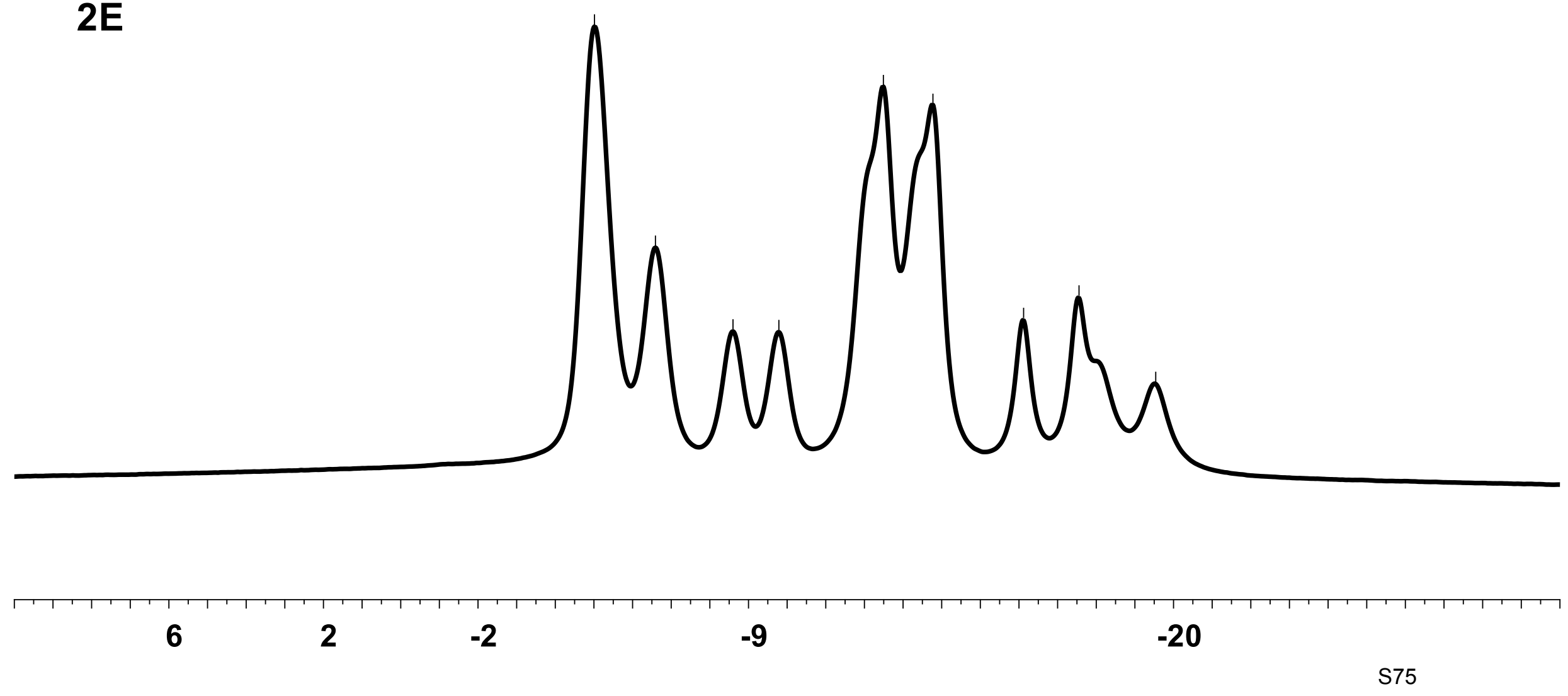

${ }^{11} B$ NMR 


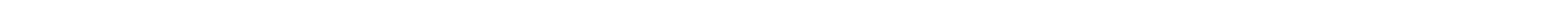




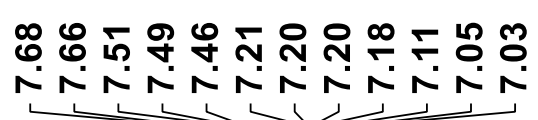

๖ั

Y
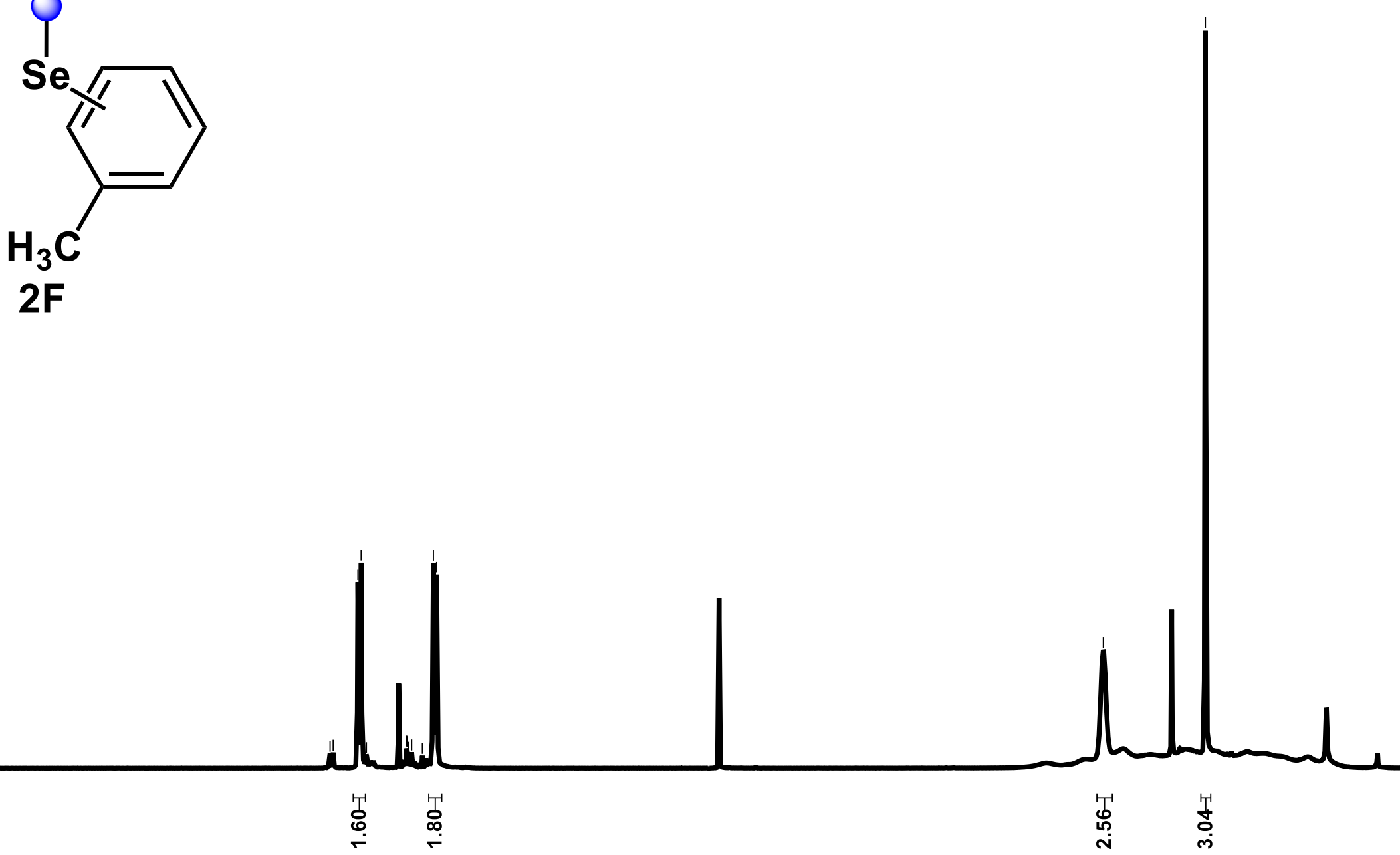

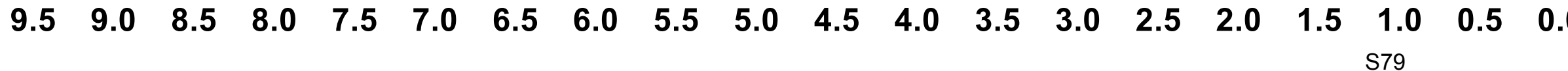
1H NMR 

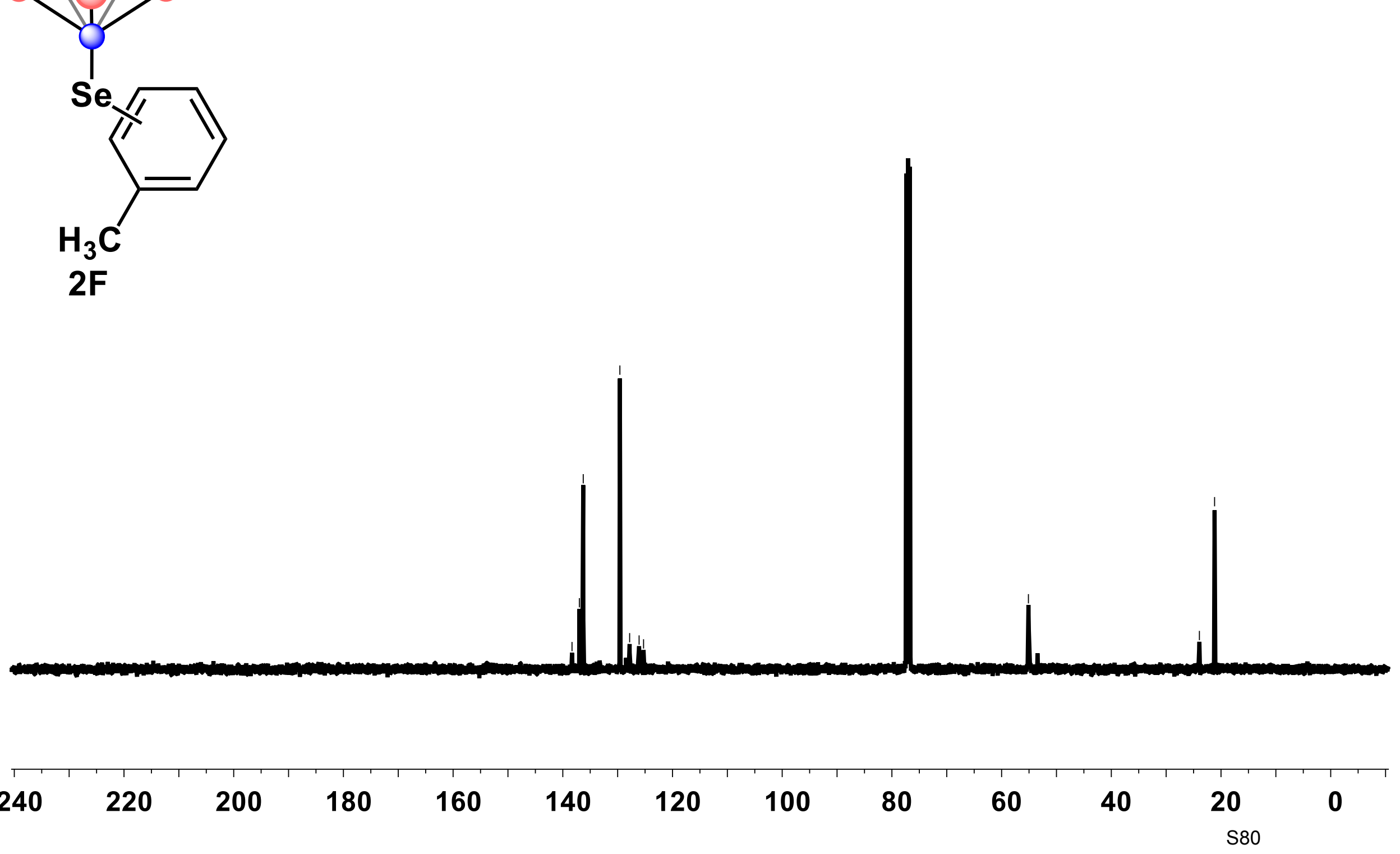
${ }^{13} \mathrm{C}\left\{{ }^{1} \mathrm{H}\right\}$ NMR 


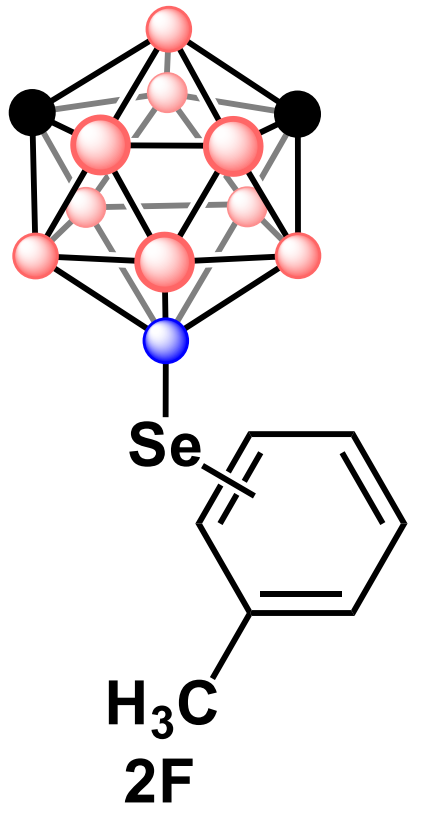

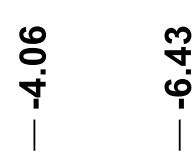

i़

芦

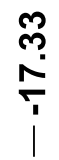

:

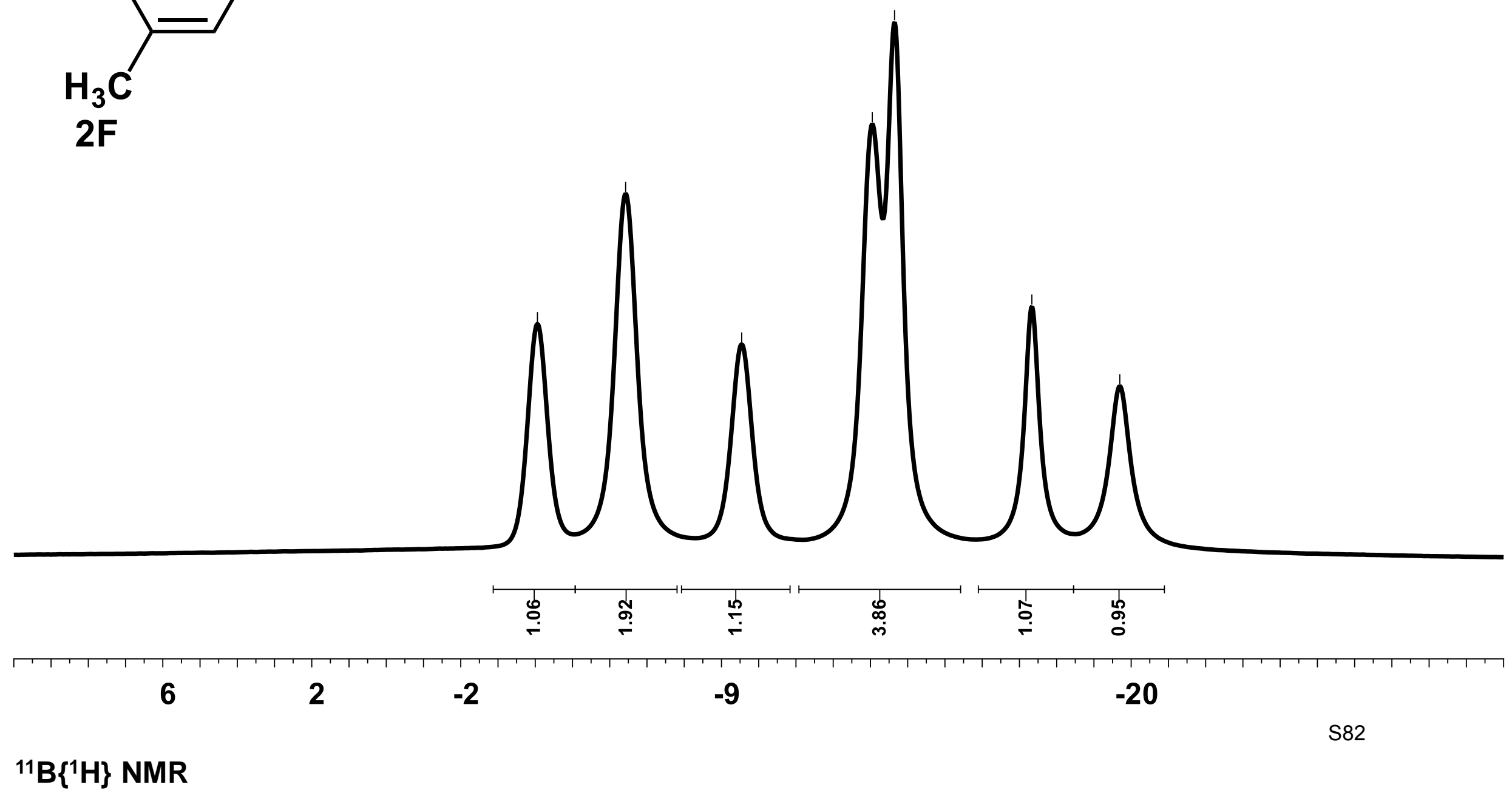

${ }^{11} \mathrm{~B}\left\{{ }^{1} \mathrm{H}\right\}$ NMR 


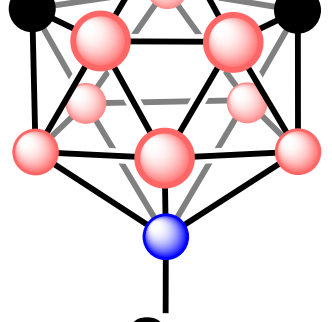

Se

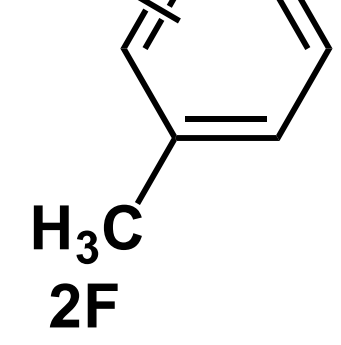

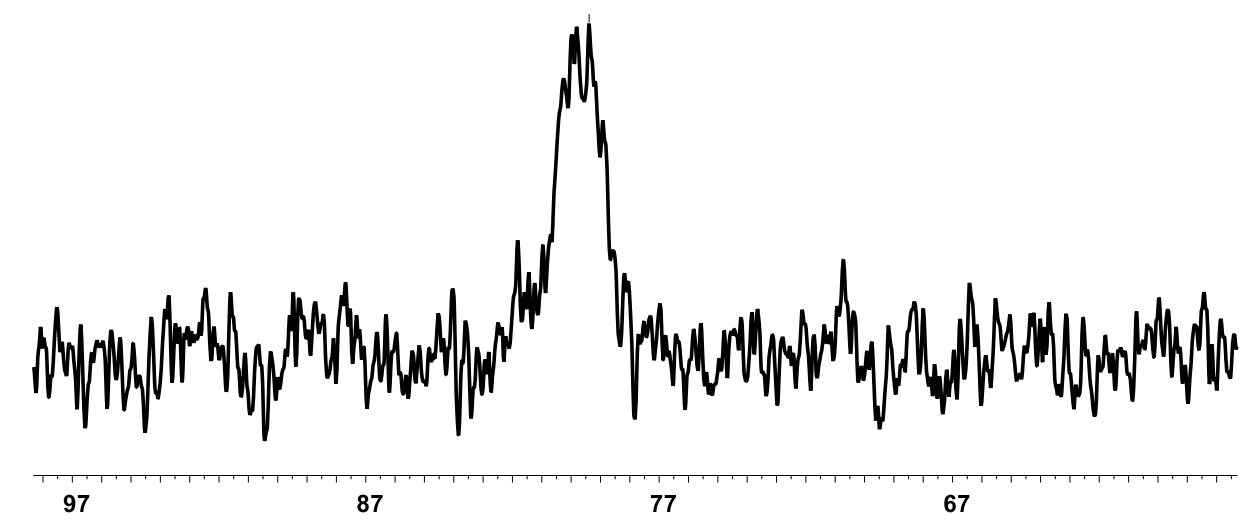

Niming

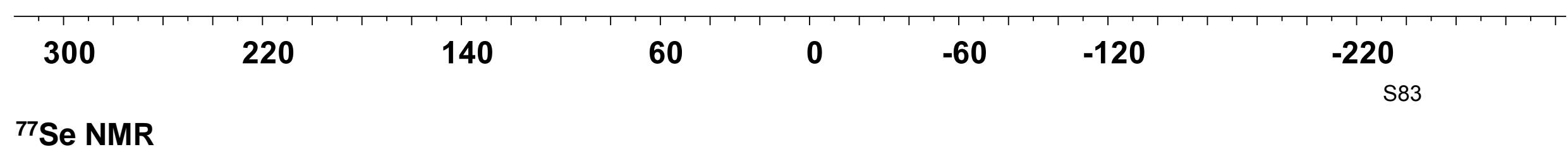




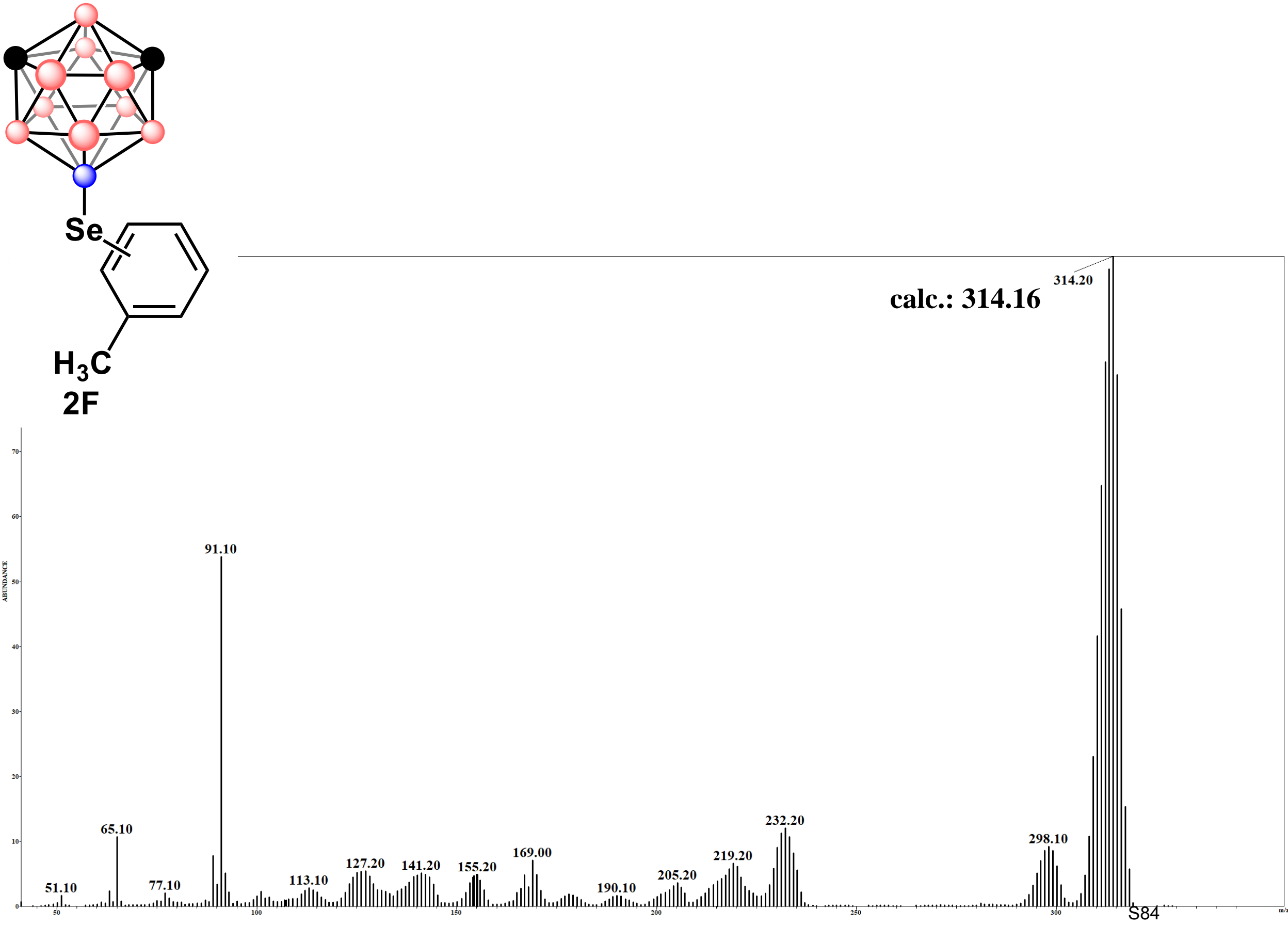

\section{GC-MS}



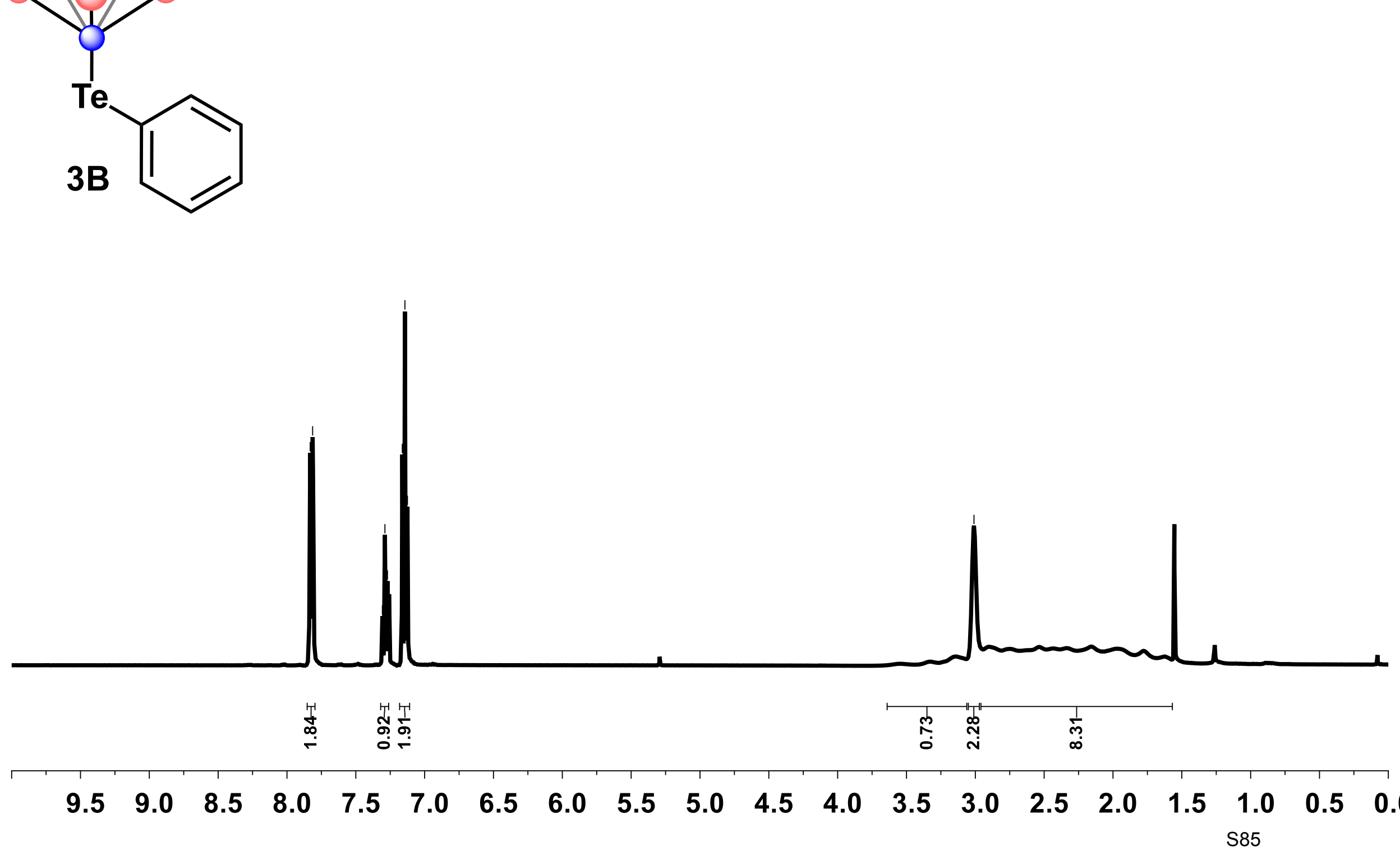
1H NMR 


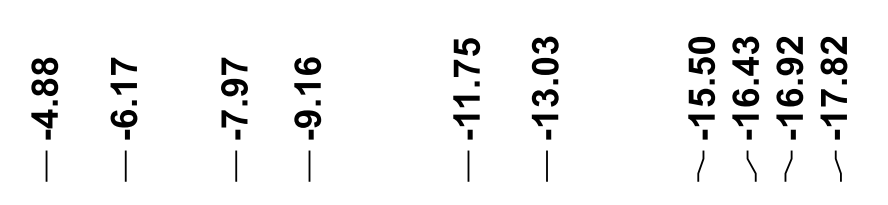

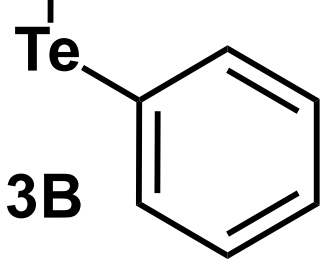




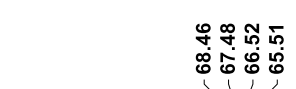

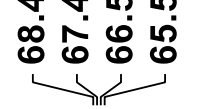

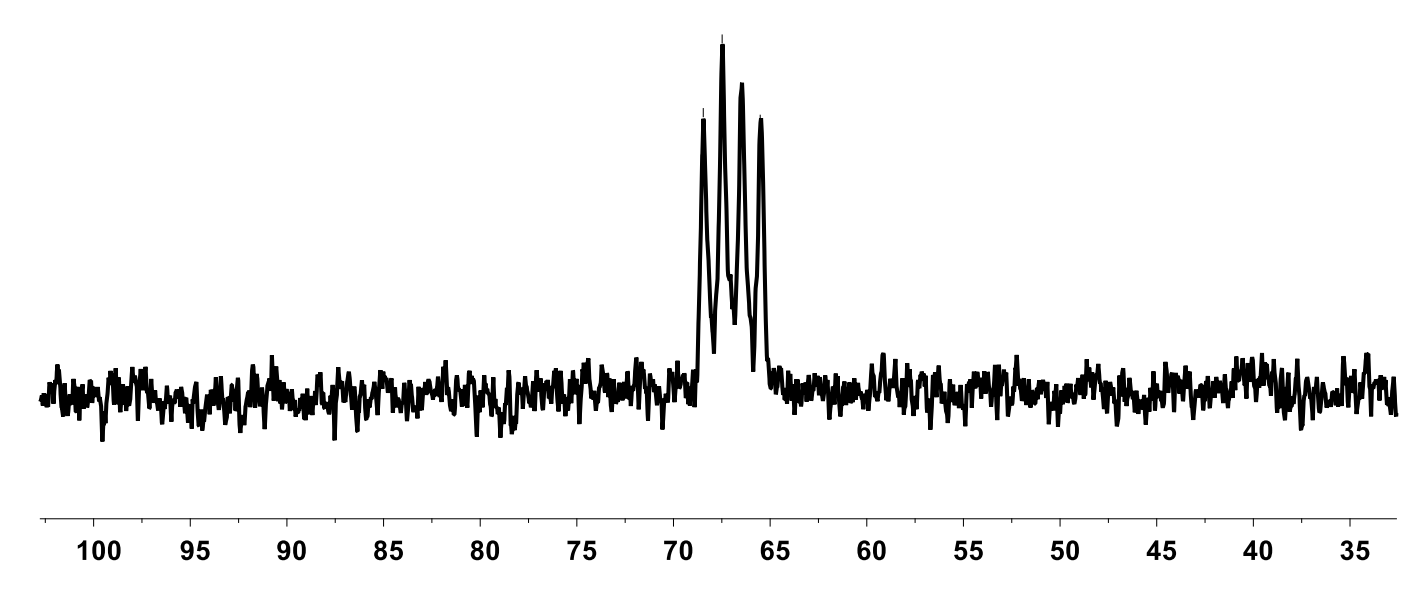

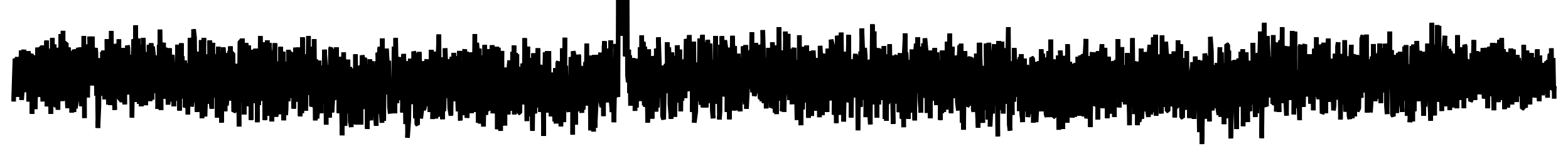

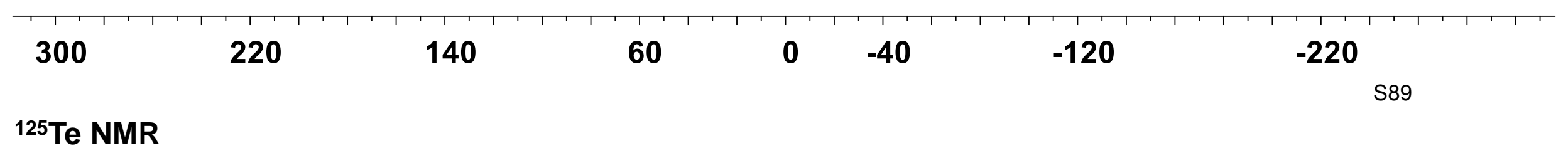



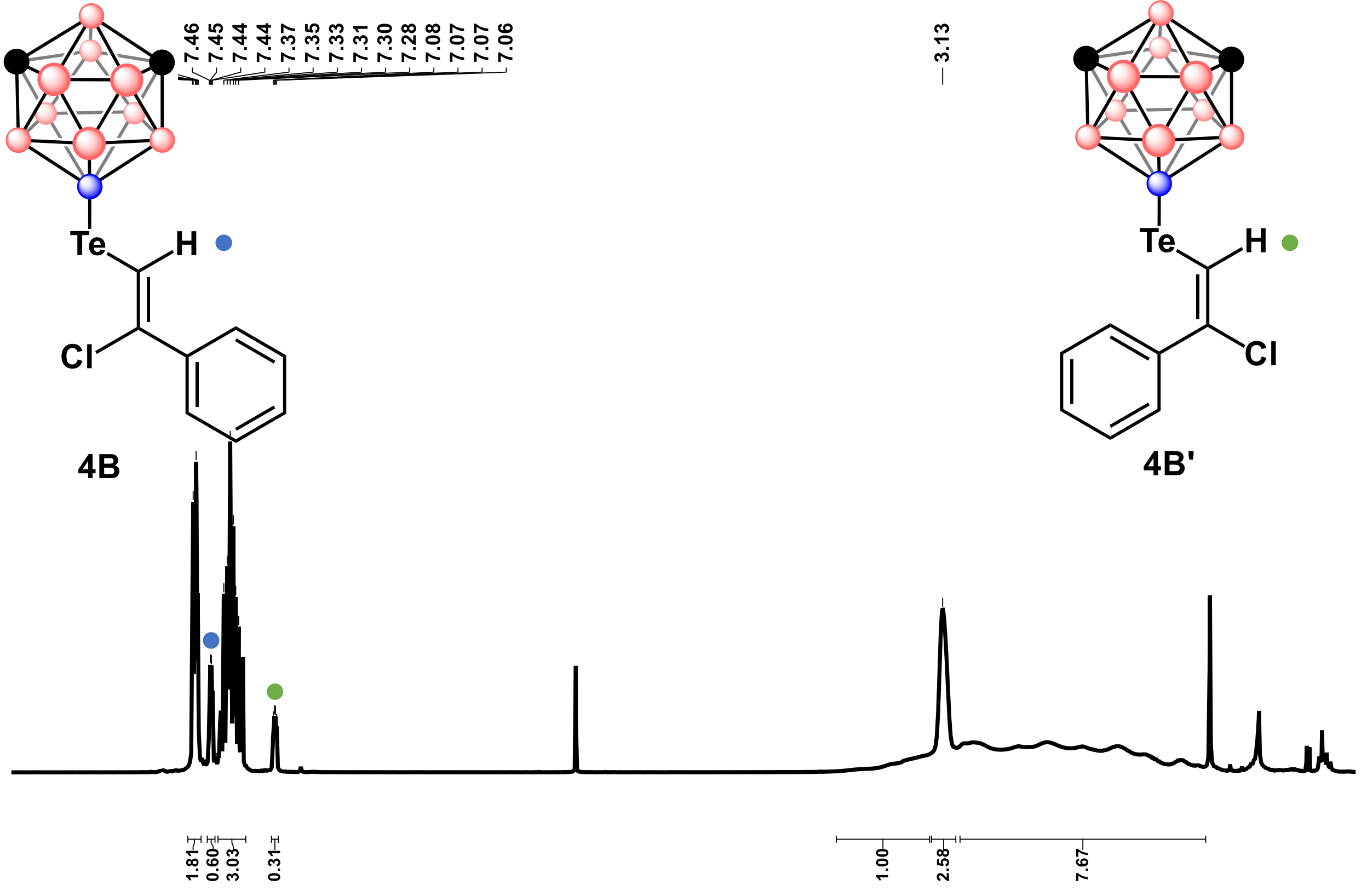

$\begin{array}{rrrrrrrrrrrrrrrr}8.5 & 8.0 & 7.5 & 7.0 & 6.5 & 6.0 & 5.5 & 5.0 & 4.5 & 4.0 & 3.5 & 3.0 & 2.5 & 2.0 & 1.5 & 1.0\end{array}$
${ }^{1} \mathrm{H}$ NMR 

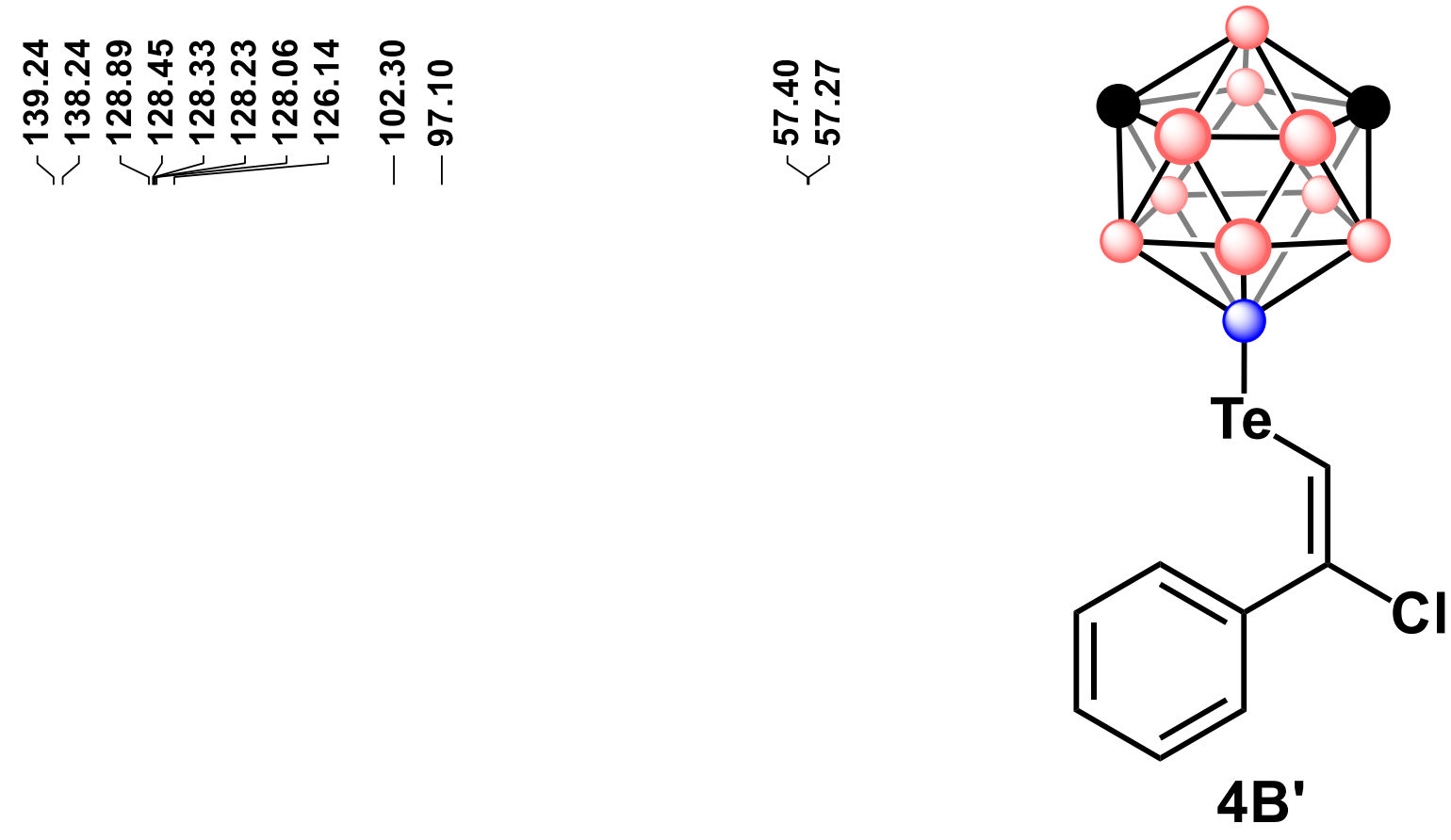

\begin{tabular}{|c|c|c|c|c|c|c|c|c|c|c|c|}
\hline 220 & 200 & 180 & 160 & 140 & 120 & 100 & 80 & 60 & 40 & 20 & 0 \\
\hline
\end{tabular}
${ }^{13} \mathrm{C}\left\{{ }^{1} \mathrm{H}\right\}$ NMR 


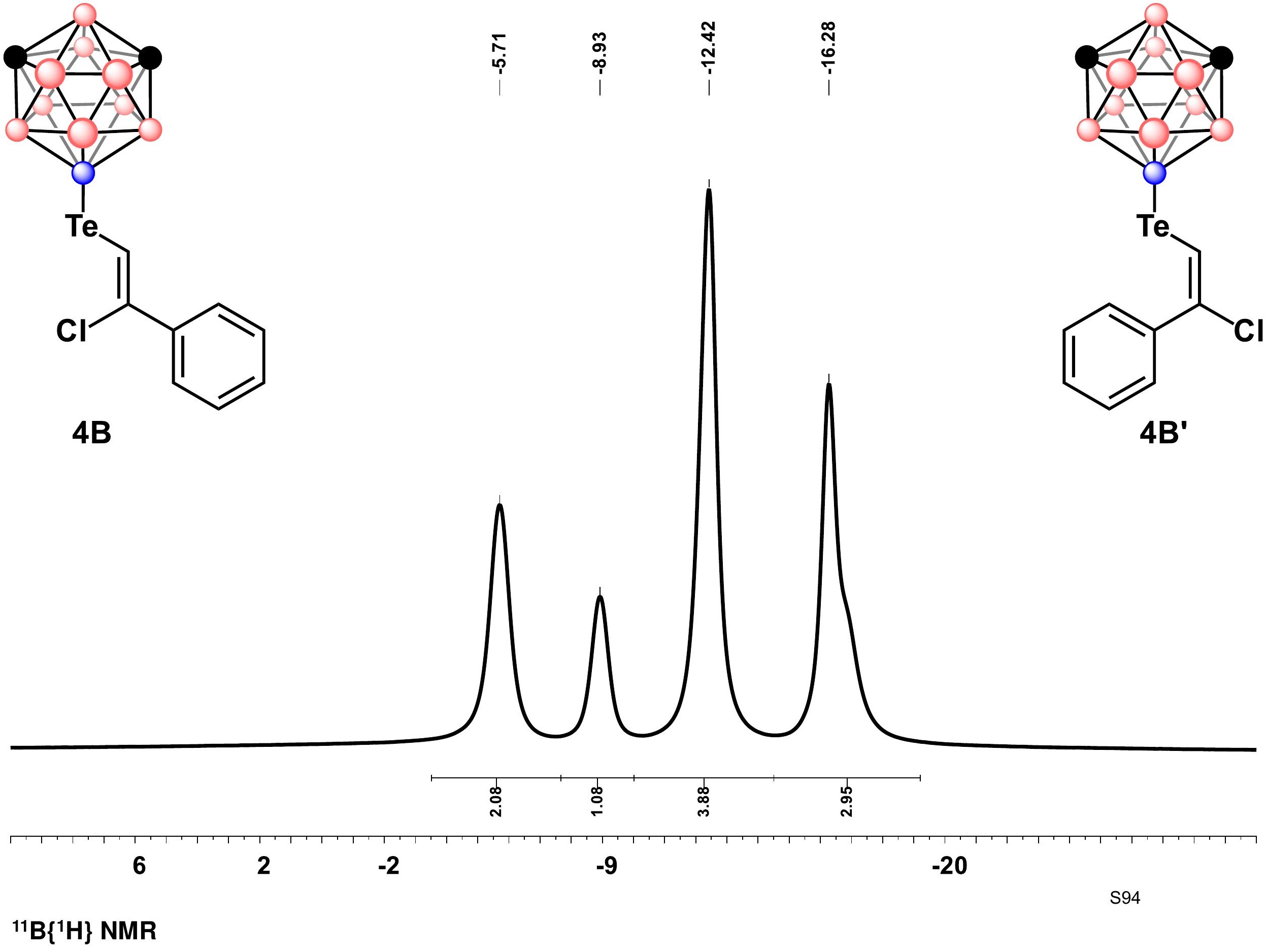




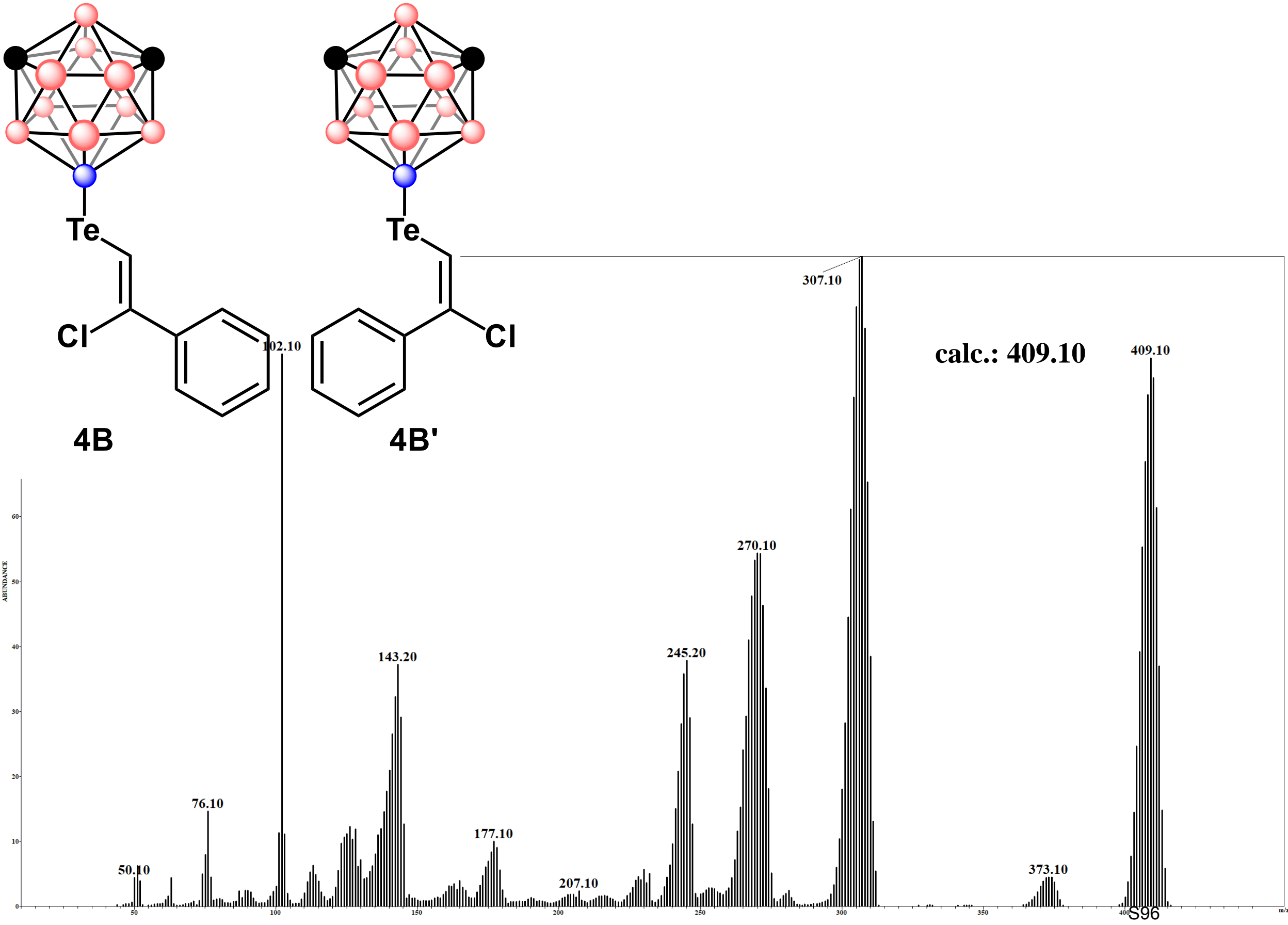

\section{GC-MS}




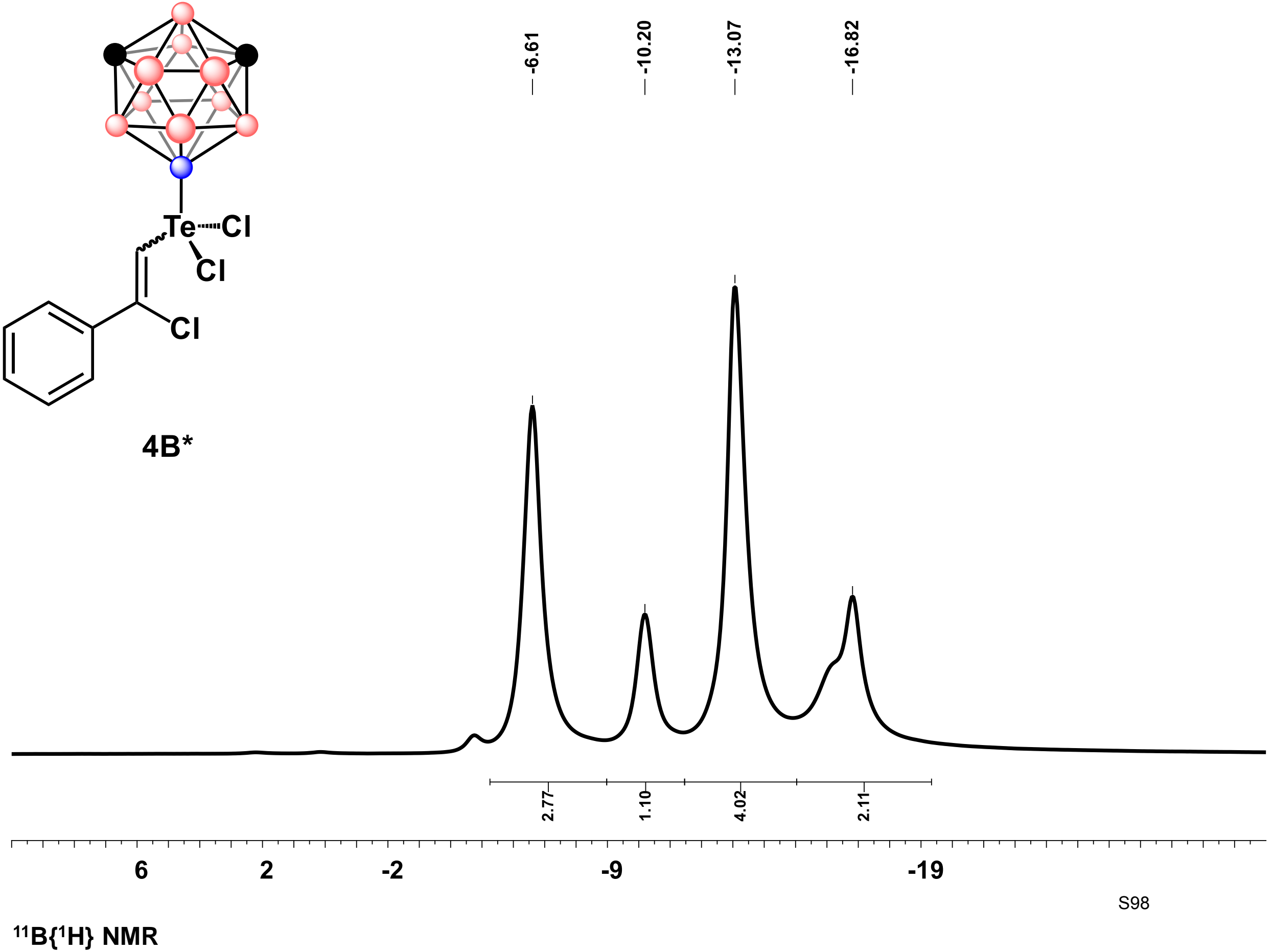



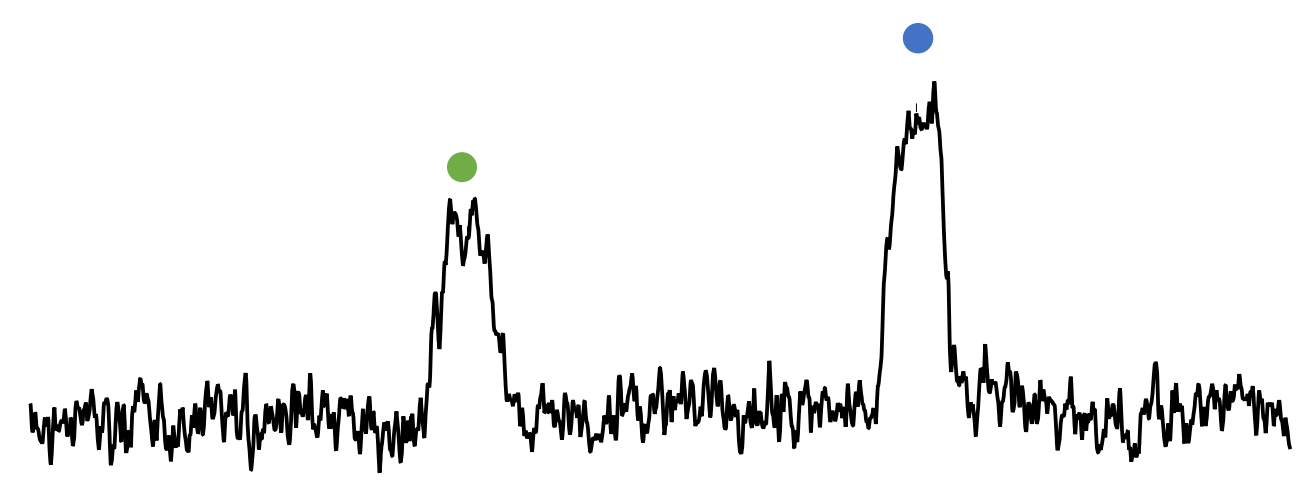

$4 B^{*}$

584

578

72

566

560

554

548

542

536

$E$ isomer:

$Z$ isomer:

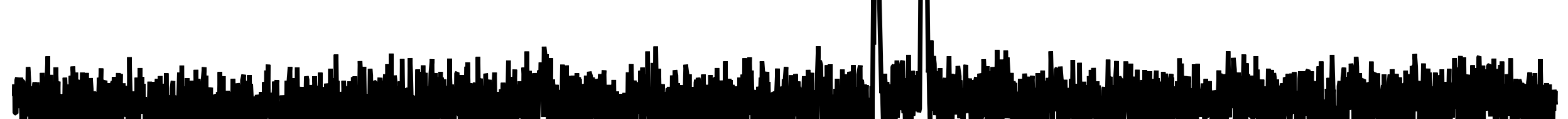

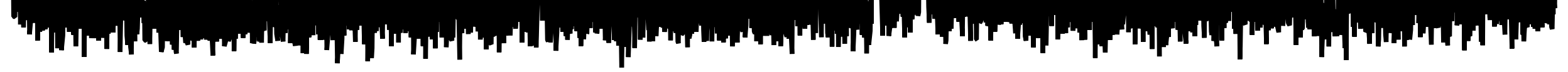

\begin{tabular}{|c|c|c|c|c|c|c|c|}
\hline 920 & 840 & 760 & 680 & 600 & 520 & 440 & $\begin{array}{r}360 \\
599\end{array}$ \\
\hline
\end{tabular}


SeH

5A

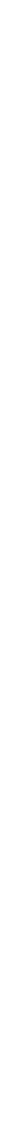
1H NMR 


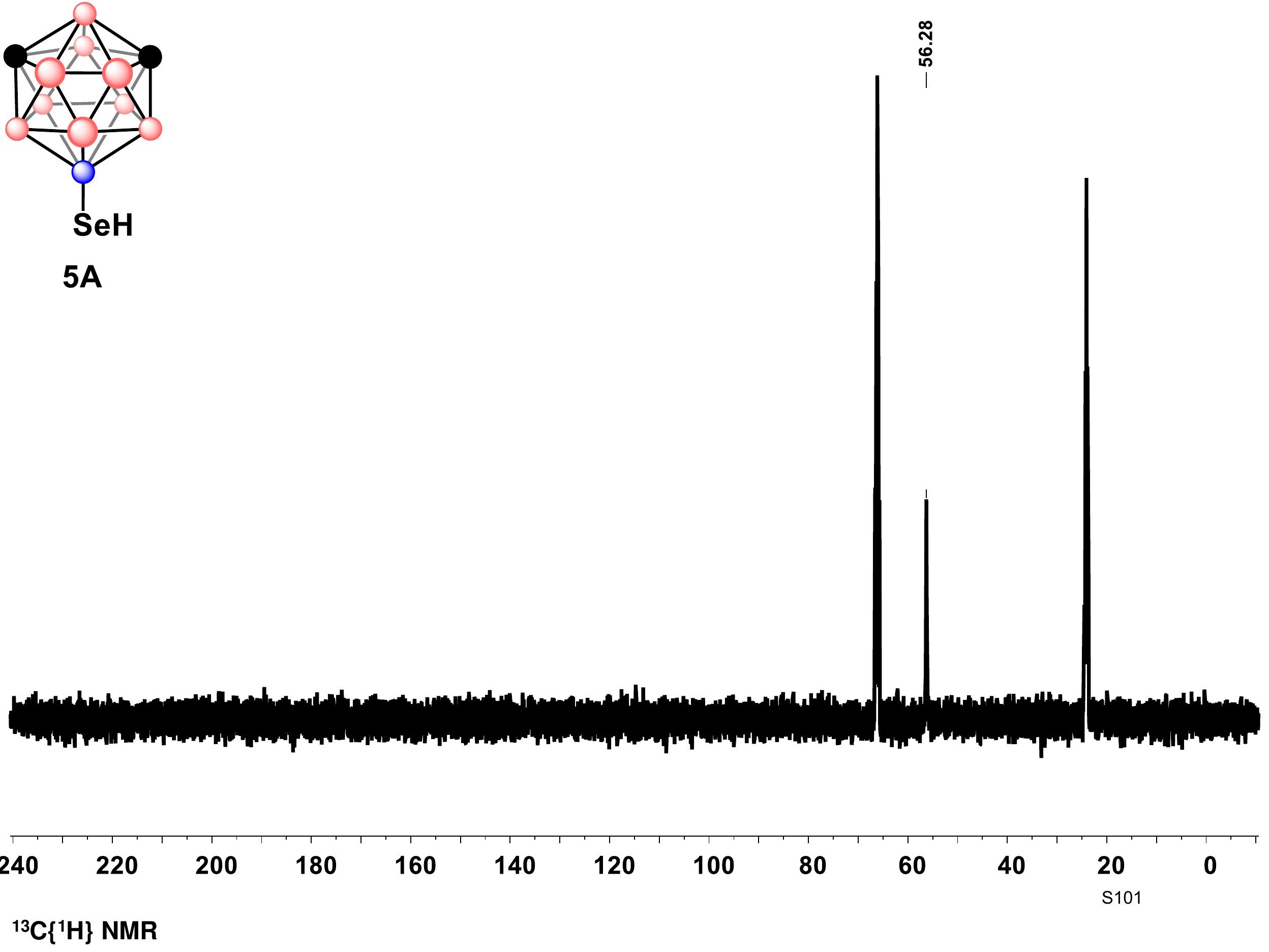




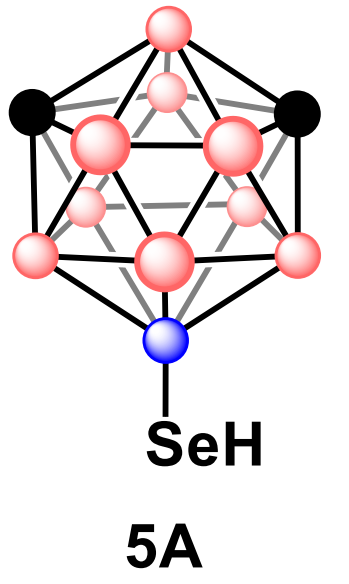

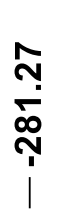



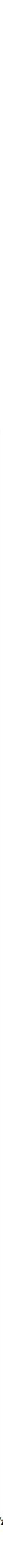

\section{GC-MS}



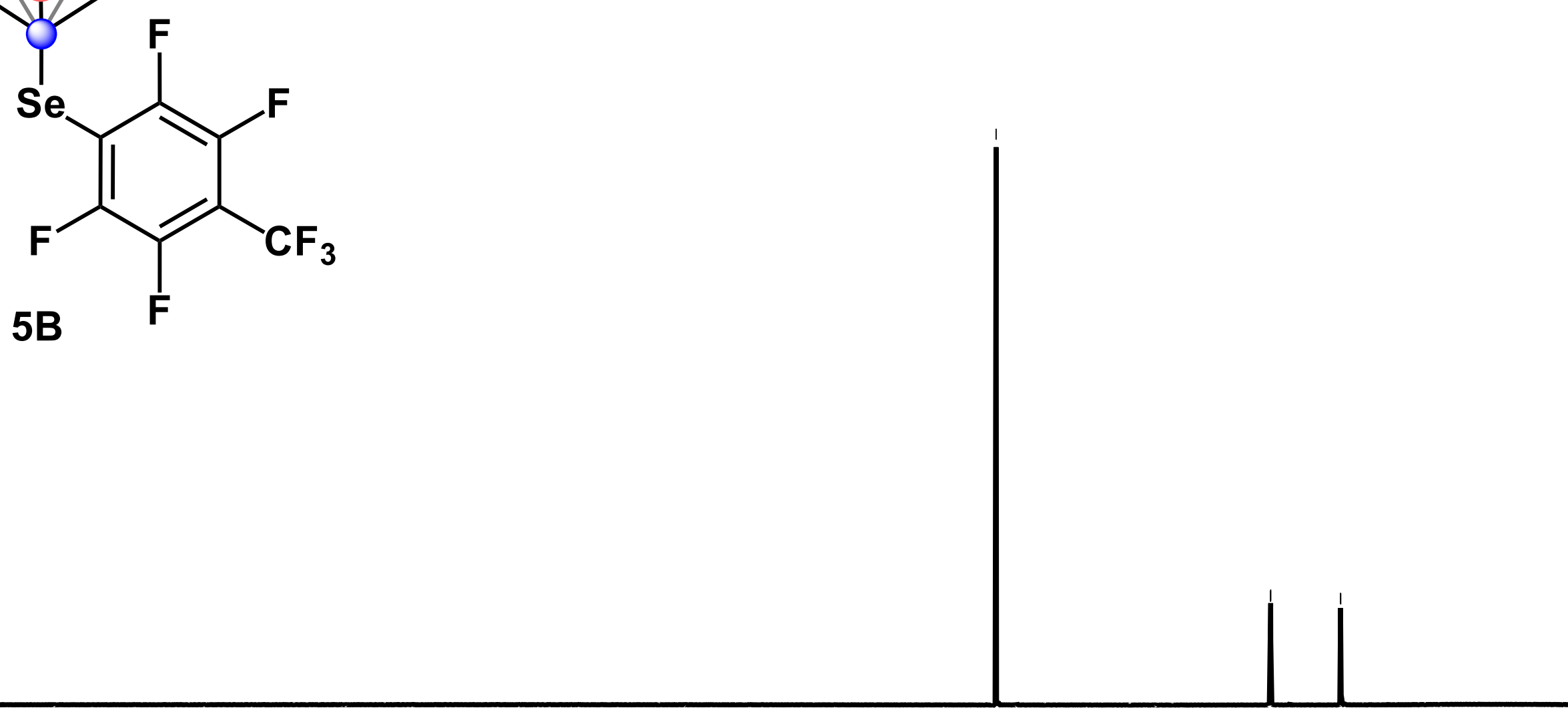

$\frac{d}{m}$

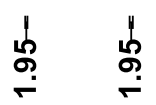



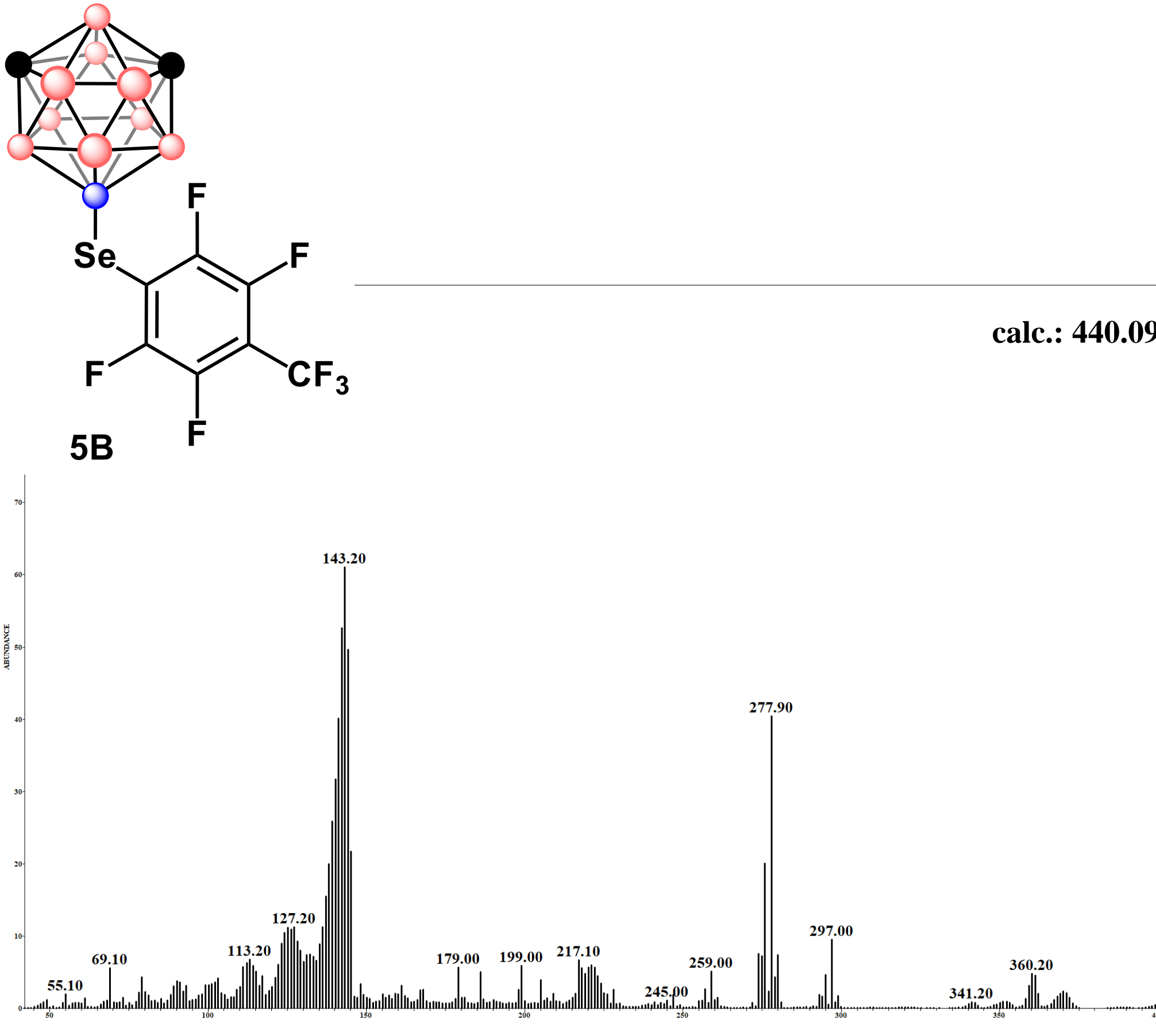

\section{GC-MS}




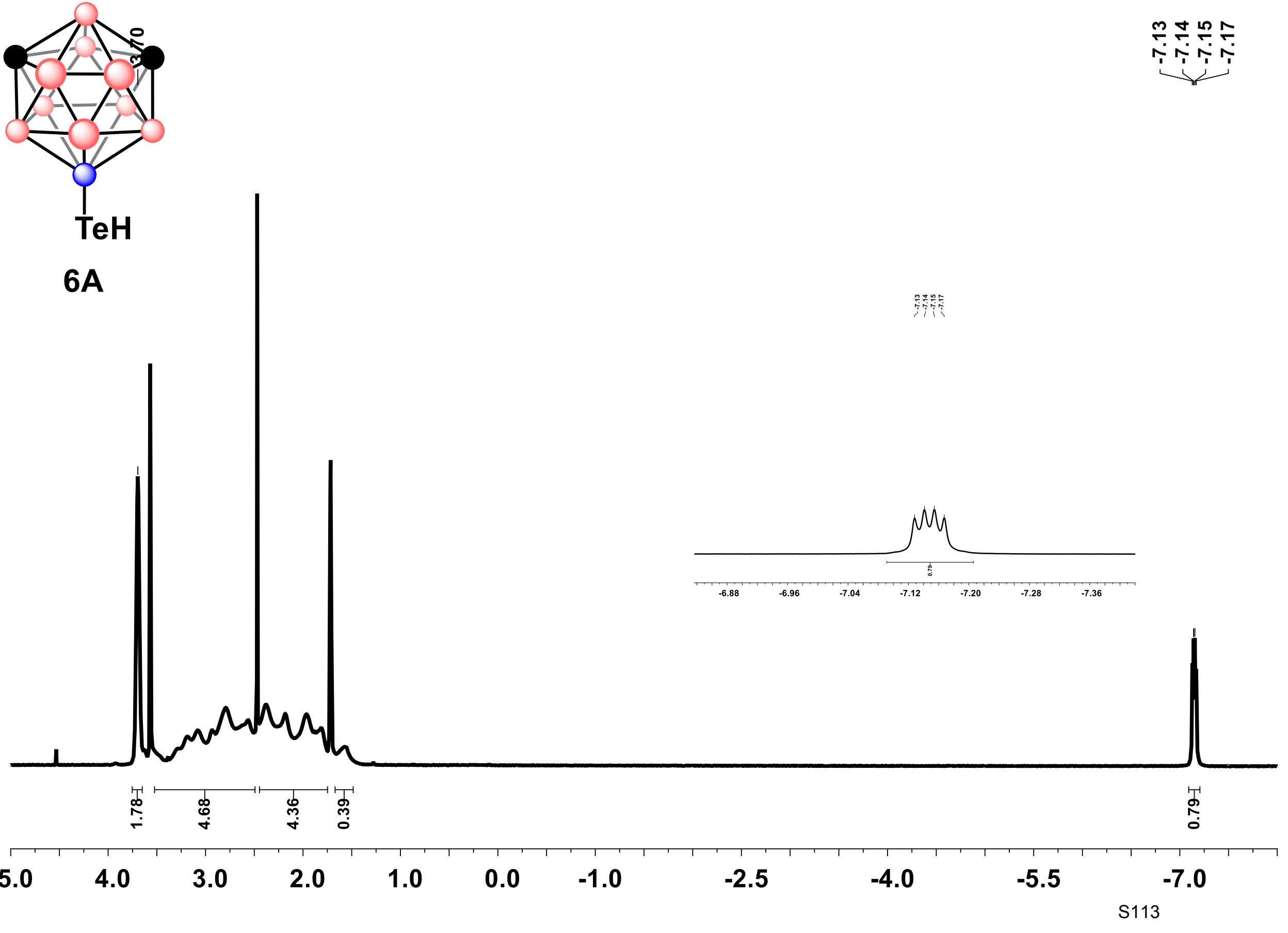
${ }^{1} \mathrm{H}$ NMR 


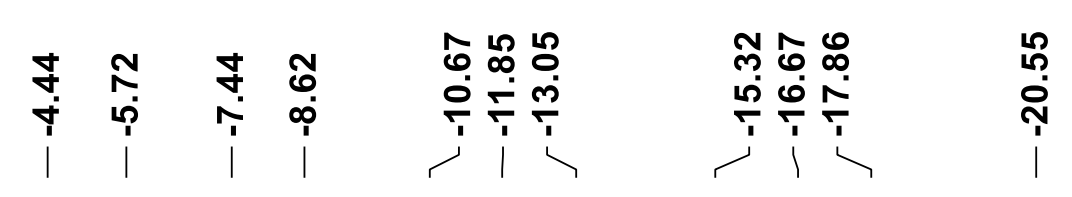

\section{TeH}

6A 
6A

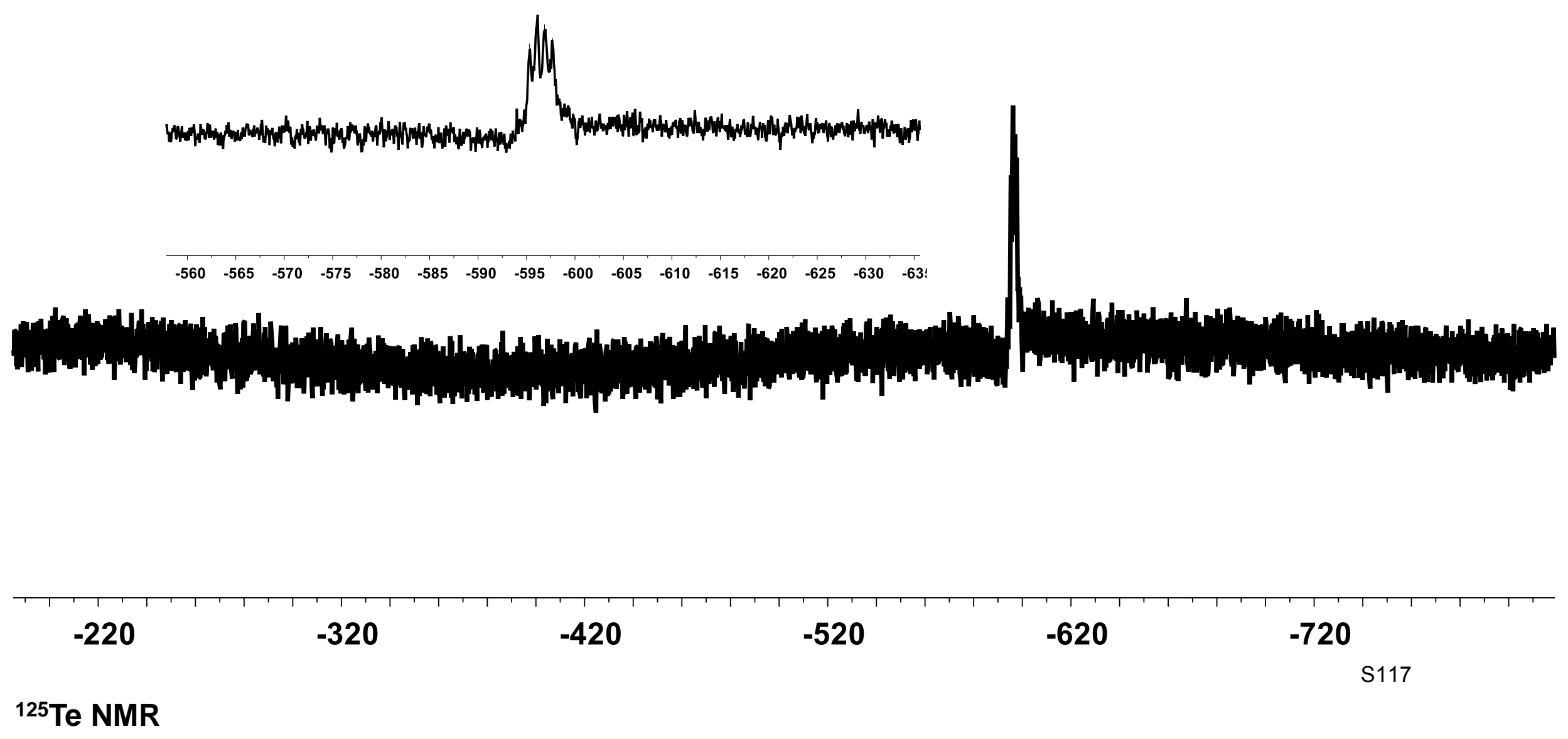

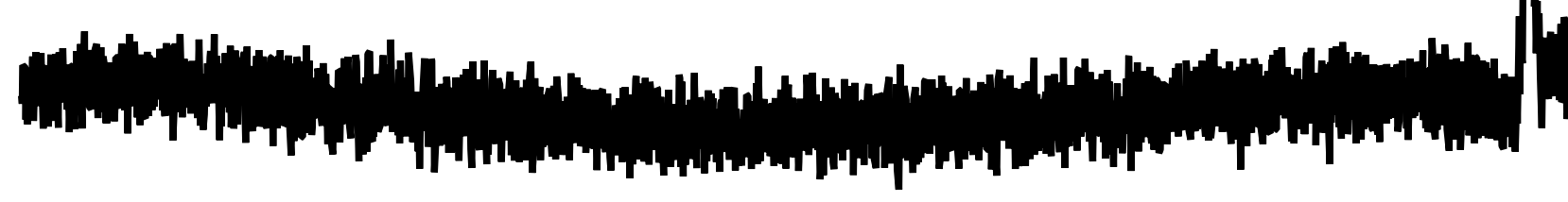



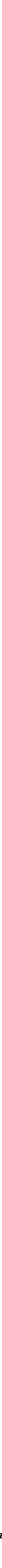

\section{GC-MS}




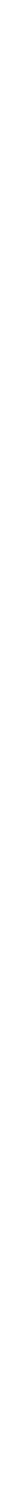

\begin{tabular}{|c|c|c|c|c|c|c|c|c|c|c|c|}
\hline 220 & 200 & 180 & 160 & 140 & 120 & 100 & 80 & 60 & 40 & $\begin{array}{l}20 \\
S 12\end{array}$ & 0 \\
\hline
\end{tabular}
${ }^{13} \mathrm{C}\left\{{ }^{1} \mathrm{H}\right\}$ NMR 

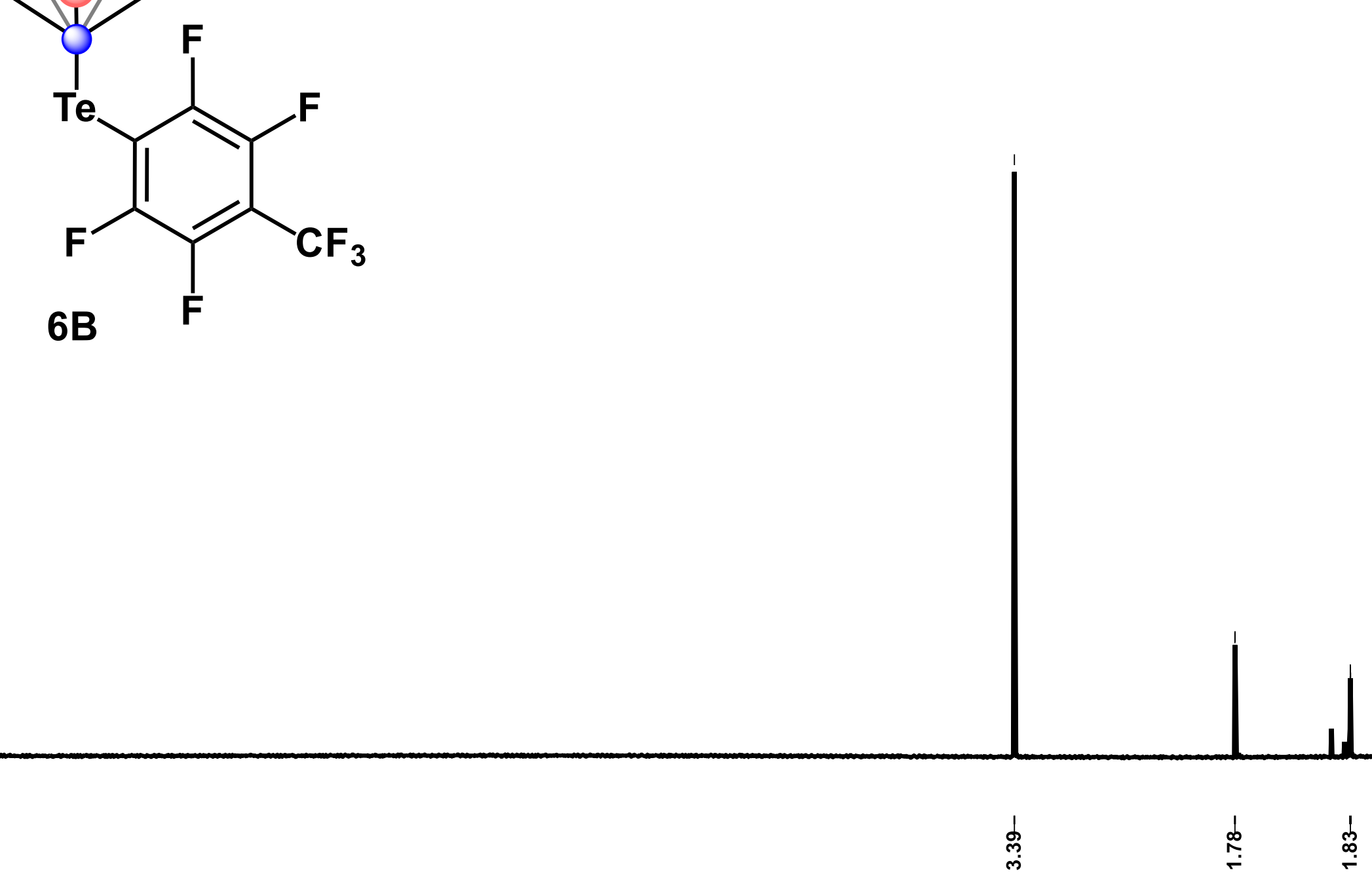


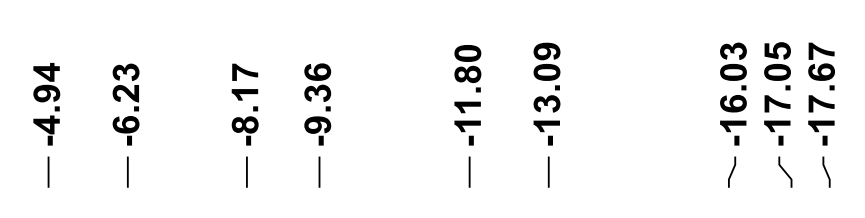

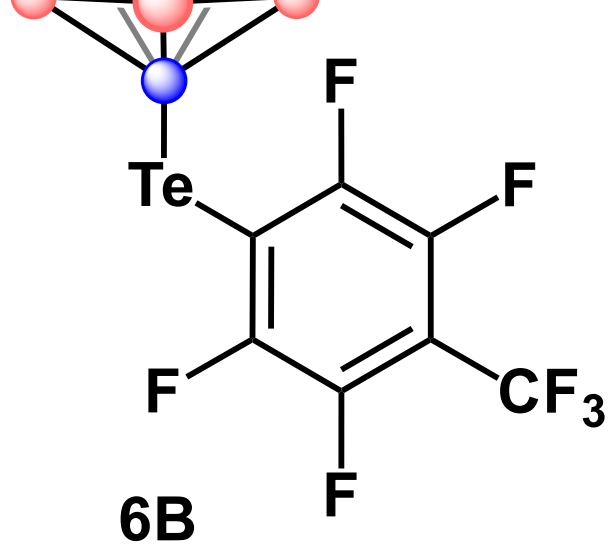



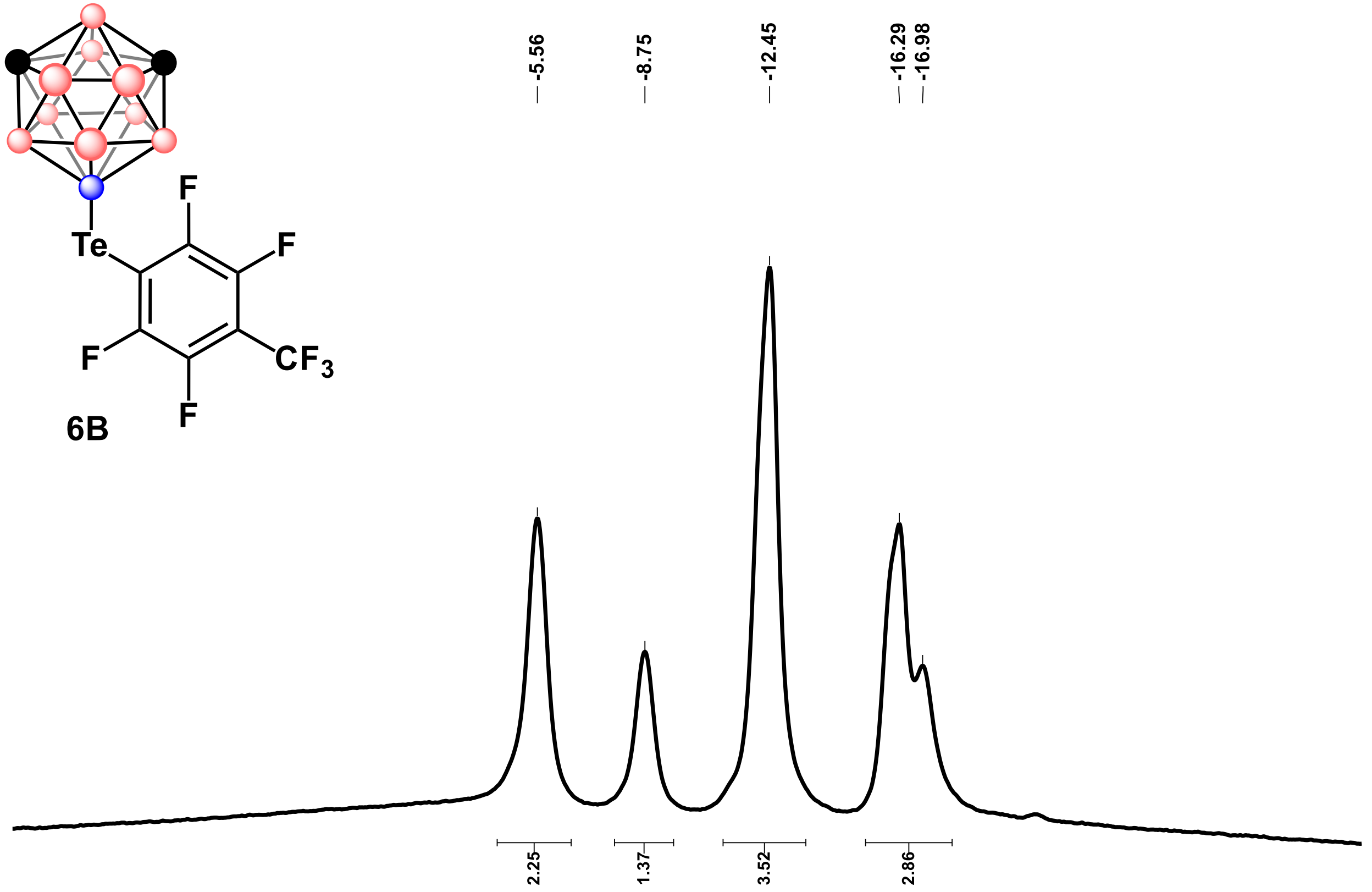

6

2

$-2$

$-9$

$-20$ 


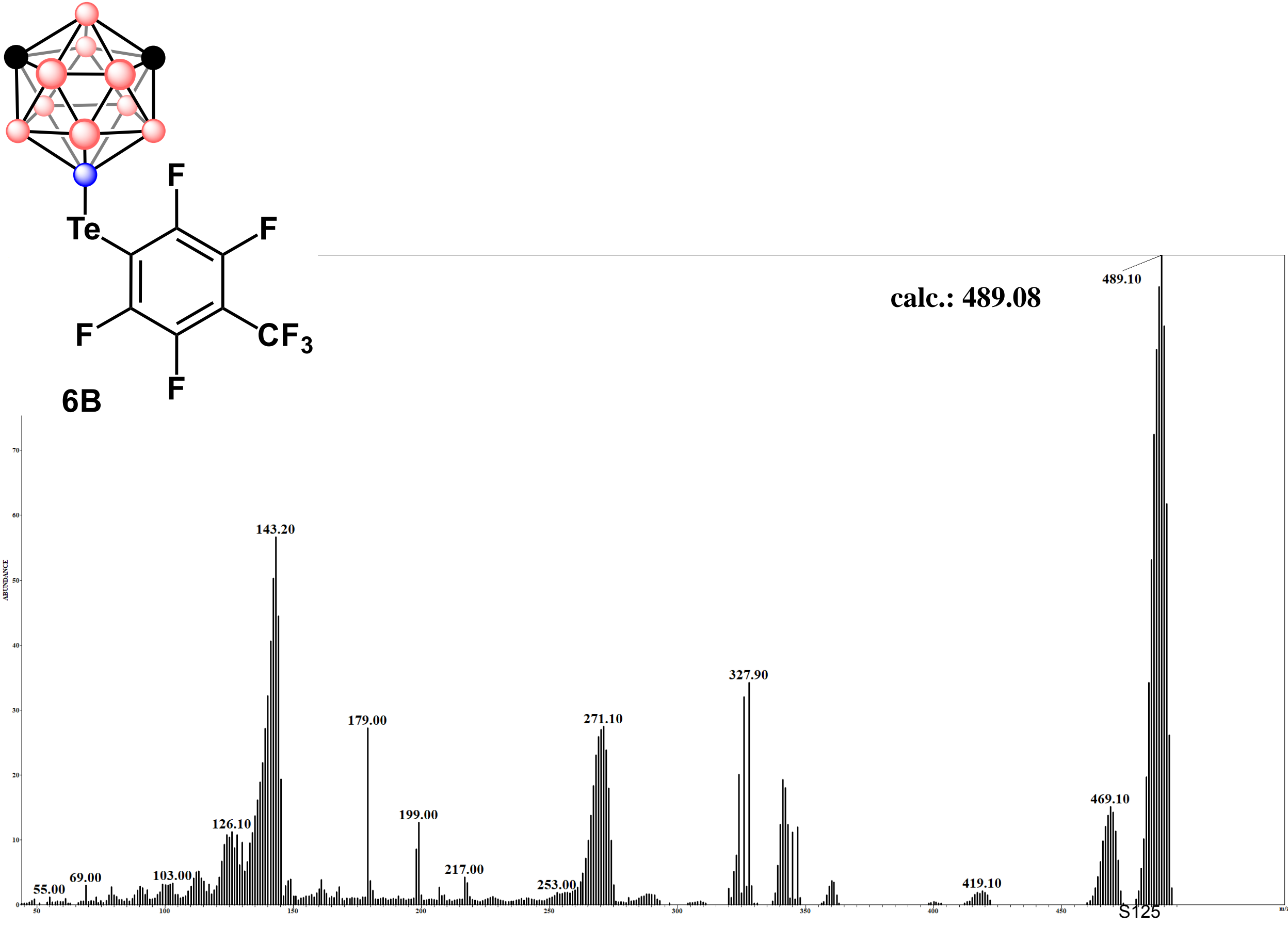

\section{GC-MS}




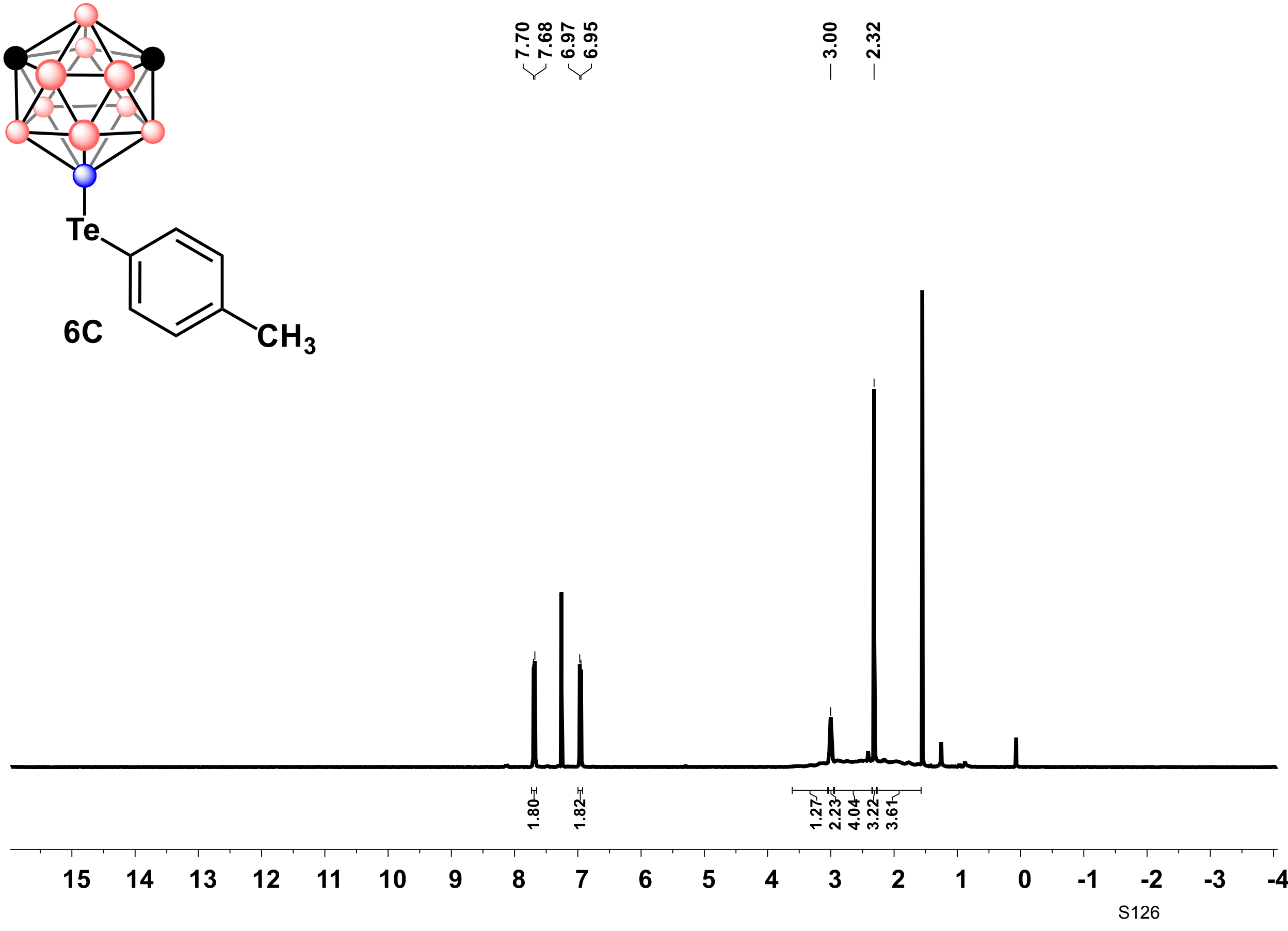
${ }^{1} \mathrm{H}$ NMR 


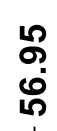

$\stackrel{\text { กิ }}{\text { ก }}$

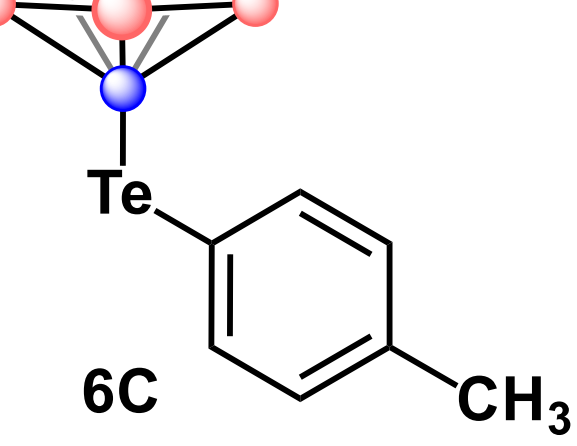

I

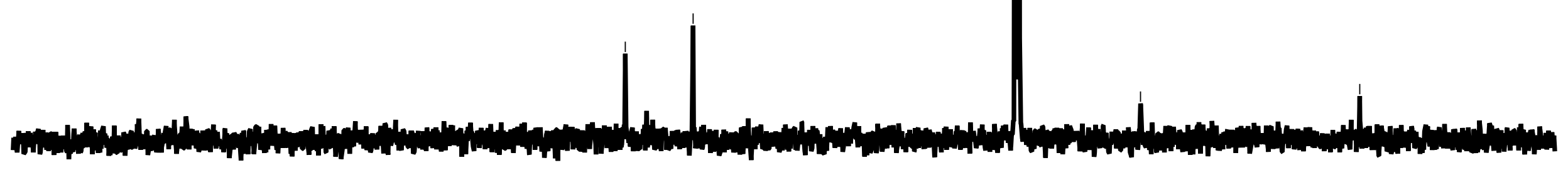

\begin{tabular}{|c|c|c|c|c|c|c|c|c|c|c|c|}
\hline 220 & 200 & 180 & 160 & 140 & 120 & 100 & 80 & 60 & 40 & $\begin{array}{l}20 \\
S 12\end{array}$ & 0 \\
\hline
\end{tabular}
${ }^{13} \mathrm{C}\left\{{ }^{1} \mathrm{H}\right\}$ NMR 


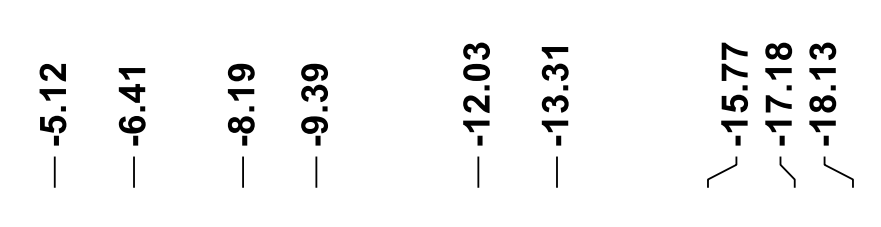<smiles>Cc1ccc([Te])cc1</smiles>

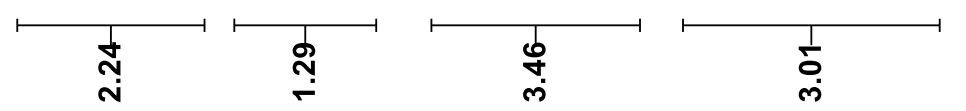

$\begin{array}{rllll}6 & 2 & -2 & -9 & -20\end{array}$




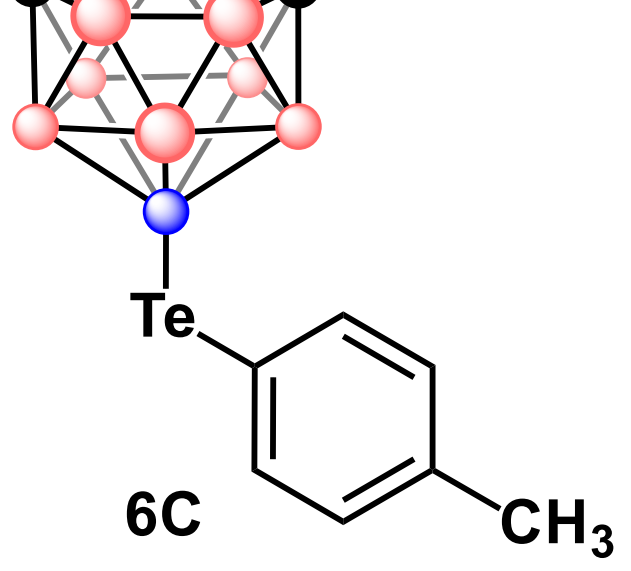

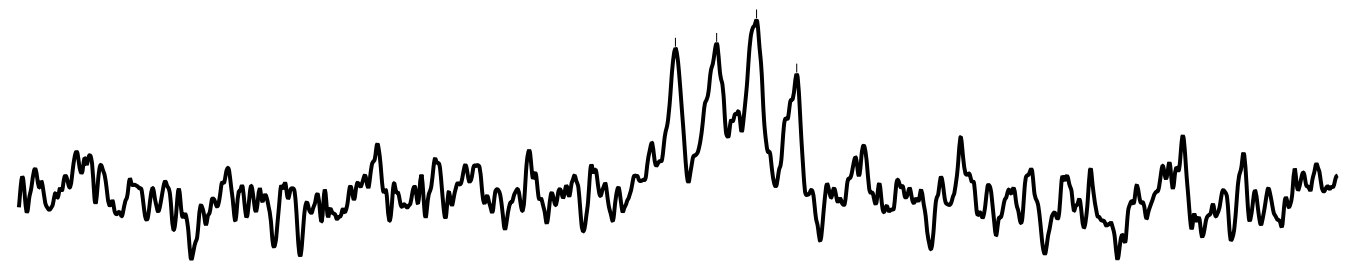

$\begin{array}{llllllllllll}64 & 61 & 58 & 55 & 52 & 49 & 46 & 43 & 40 & 37 & 34\end{array}$

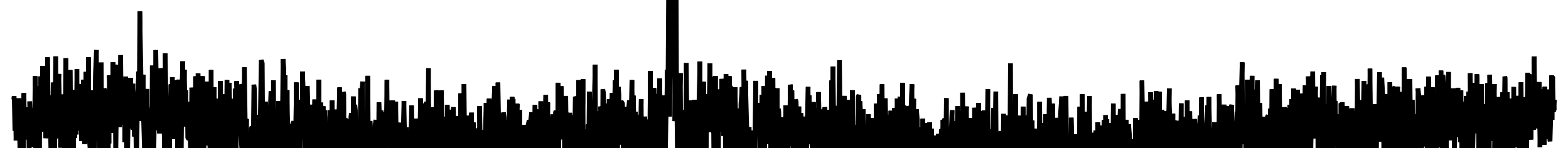
NH,

\begin{tabular}{|c|c|c|c|c|c|c|c|}
\hline 300 & 220 & 140 & 60 & 0 & -40 & -120 & -220 \\
\hline
\end{tabular}


